Prepared in cooperation with the IDAHO DEPARTMENT OF WATER RESOURCES WASHINGTON STATE DEPARTMENT OF ECOLOGY UNIVERSITY OF IDAHO

\title{
Ground-Water Flow Model for the Spokane Valley-Rathdrum Prairie Aquifer, Spokane County, Washington, and Bonner and Kootenai Counties, Idaho
}

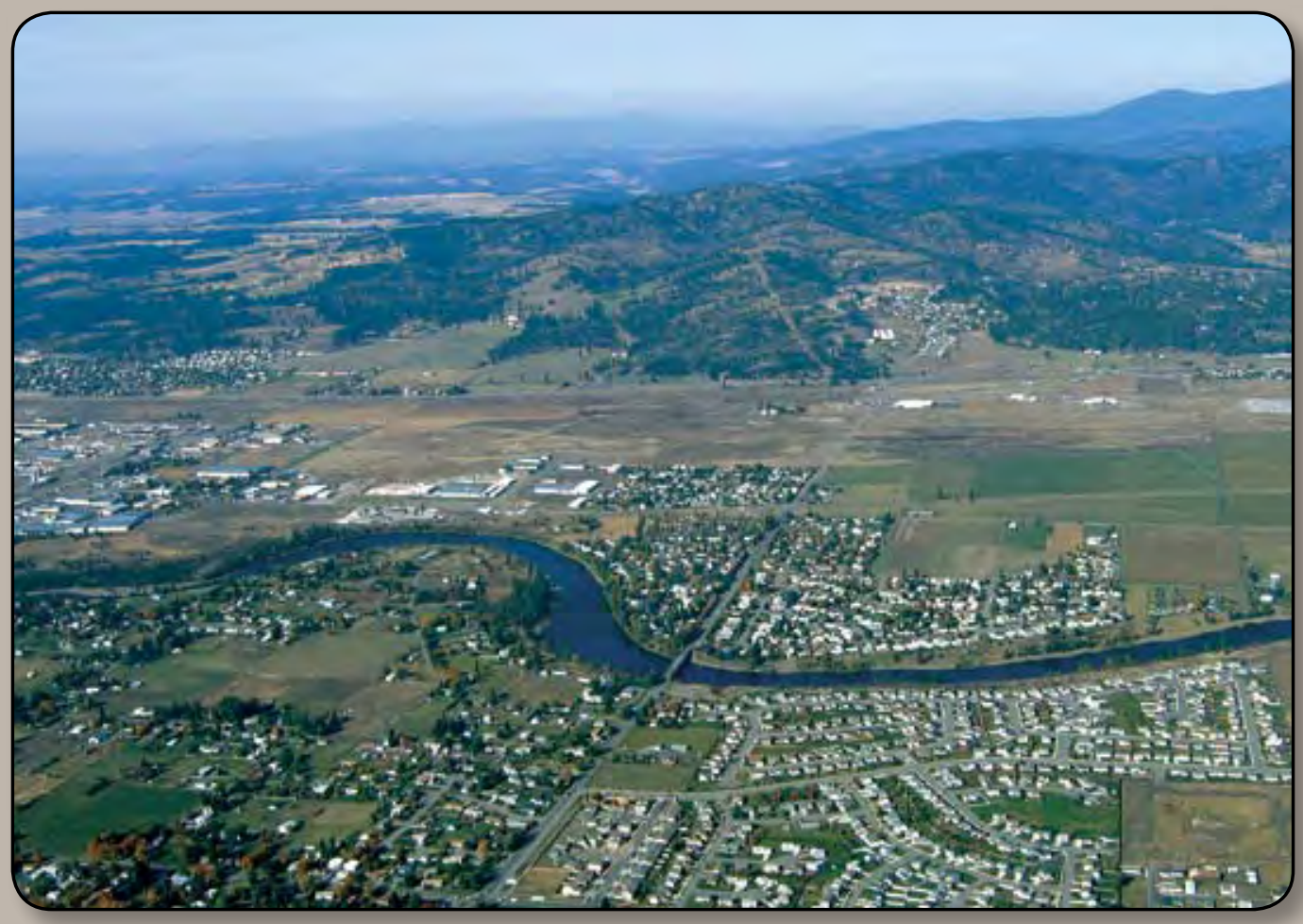

Scientific Investigations Report 2007-5044 
Cover: Photograph of Spokane Valley, Washington. The U.S. Geological Survey streamflow gaging station on the Spokane River at Greenacres, Washington, is to the right (upstream) of where Barker Road Bridge crosses the river. (Photograph taken by Paul Hsieh, U.S. Geological Survey, 2005.) 


\section{Ground-Water Flow Model for the Spokane Valley-Rathdrum Prairie Aquifer, Spokane County, Washington, and Bonner and Kootenai Counties, Idaho}

By Paul A. Hsieh, Michael E. Barber, Bryce A. Contor, Md. Akram Hossain, Gary S. Johnson, Joseph L. Jones, and Allan H. Wylie

Prepared in cooperation with the

Idaho Department of Water Resources,

Washington State Department of Ecology,

University of Idaho, and

Washington State University

Scientific Investigations Report 2007-5044 


\title{
U.S. Department of the Interior DIRK KEMPTHORNE, Secretary
}

\author{
U.S. Geological Survey \\ Mark D. Myers, Director
}

\section{U.S. Geological Survey, Reston, Virginia: 2007}

For product and ordering information:

World Wide Web: http://www.usgs.gov/pubprod

Telephone: 1-888-ASK-USGS

For more information on the USGS--the Federal source for science about the Earth, its natural and living resources, natural hazards, and the environment:

World Wide Web: http://www.usgs.gov

Telephone: 1-888-ASK-USGS

Any use of trade, product, or firm names is for descriptive purposes only and does not imply endorsement by the U.S. Government.

Although this report is in the public domain, permission must be secured from the individual copyright owners to reproduce any copyrighted materials contained within this report.

Suggested citation:

Hsieh, P.A., Barber, M.E., Contor, B.A., Hossain, Md. A., Johnson, G.S., Jones, J.L., and Wylie, A.H., 2007,

Ground-water flow model for the Spokane Valley-Rathdrum Prairie Aquifer, Spokane County, Washington, and Bonner and Kootenai Counties, Idaho: U.S. Geological Survey Scientific Investigations Report 2007-5044, 78 p. 


\section{Contents}

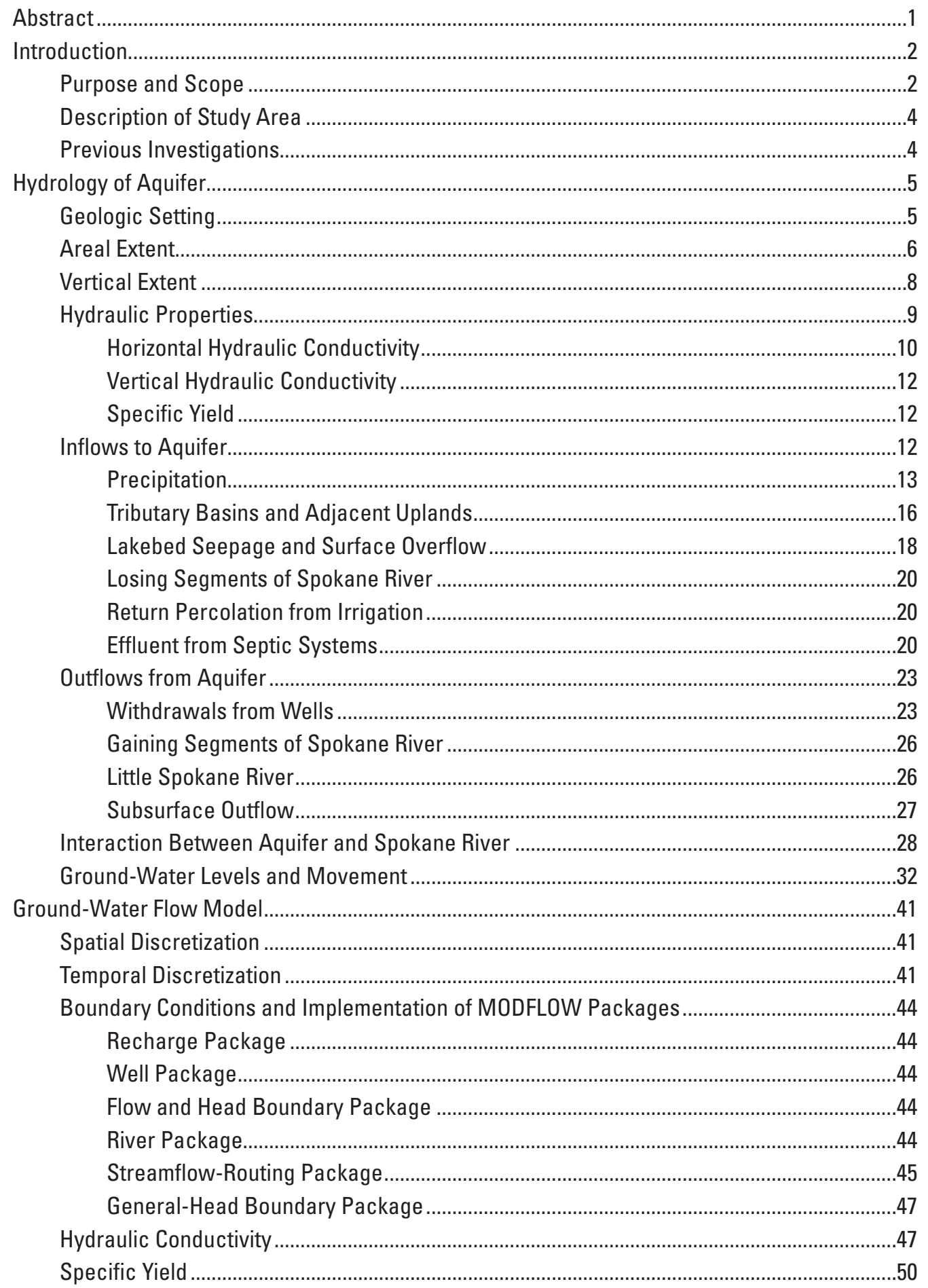




\section{Contents-Continued}

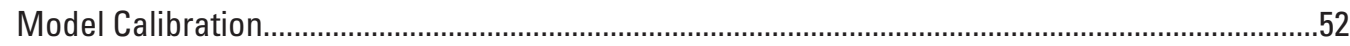

Nonlinear Least-Squares Regression Method ........................................................................52

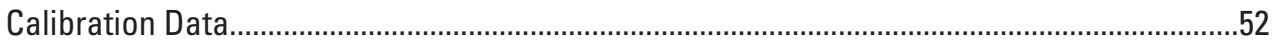

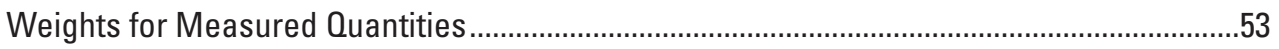

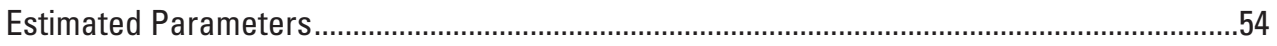

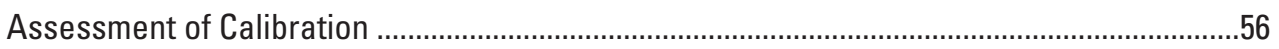

Simulated Flows in Aquifer ...........................................................................................67

Alternative Models .......................................................................................................68

Model Limitations and Suggestions for Future Work ...................................................................73

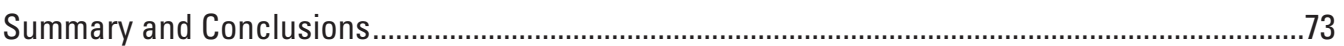

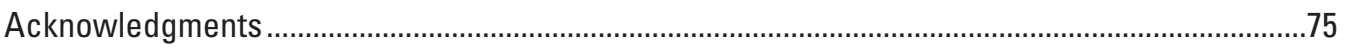

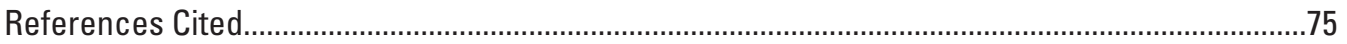

\section{Figures}

Figure 1. Map showing location of the Spokane Valley-Rathdrum Prairie aquifer, Spokane County, Washington, and Bonner and Kootenai Counties, Idaho

Figure 2. Map showing locations of wells in and near Spirit and Hoodoo Valleys, Bonner County, Idaho

Figure 3. Map showing approximate altitude of the base of the Spokane Valley-Rathdrum Prairie aquifer, Spokane County, Washington, and Bonner and Kootenai Counties, Idaho

Figure 4. Map showing areal extent of clay layer in Hillyard Trough and the Little Spokane River Arm, Spokane County, Washington

Figure 5. Generalized hydrogeologic section of the Spokane Valley-Rathdrum Prairie aquifer along hydrogeologic section C-C' (from Kahle and Bartolino, 2007)

Figure 6. Map showing locations of multiple-well aquifer-test sites in the west half of the Spokane Valley-Rathdrum Prairie aquifer, Washington and Idaho

Figure 7. Map showing locations of weather stations, auxiliary vertices, and expanded triangular network used for interpolation of recharge from precipitation on permeable surfaces, Spokane Valley-Rathdrum Prairie aquifer, Washington and Idaho

Figure 8. Graph showing depth to water in well 251 and monthly rate of deep percolation at the base of the root zone at the well site, Spokane Valley-Rathdrum Prairie aquifer, Washington and Idaho 15

Figure 9. Graph showing volumetric rate of recharge from precipitation, Spokane Valley-Rathdrum Prairie aquifer, Washington and Idaho 16

Figure 10. Map showing tributary basins that drain to the Spokane Valley-Rathdrum Prairie aquifer and to seven lakes that border the aquifer, Washington and Idaho 


\section{Figures-Continued}

Figure 11. Graph showing scaling index used to compute monthly flow from tributary basins to the Spokane Valley-Rathdrum Prairie aquifer, Washington and Idaho ... 18

Figure 12. Map showing water purveyor service areas and areal distribution of water purveyor wells, Spokane Valley-Rathdrum Prairie aquifer, 2000-02 .............. 21

Figure 13. Graph showing volumetric rate of return percolation from irrigation and effluent from septic systems, Spokane Valley-Rathdrum Prairie aquifer,

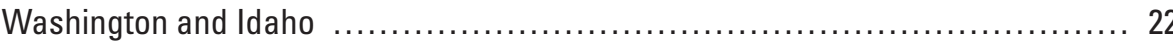

Figure 14. Map showing sewer hookup density for 2000, Spokane Valley-Rathdrum

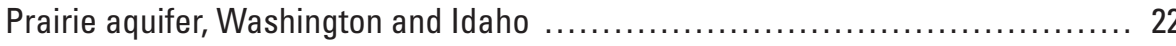

Figure 15. Graph showing withdrawal rates from wells, Spokane Valley-Rathdrum Prairie aquifer, Washington and Idaho

Figure 16. Graph showing estimated monthly withdrawal rate for a home outside water purveyor service areas, Spokane Valley-Rathdrum Prairie aquifer, Washington and Idaho

Figure 17. Map showing irrigation density for acreages outside water purveyor service areas and for self-supplied golf courses, Spokane Valley-Rathdrum Prairie aquifer, Washington and Idaho

Figure 18. Map showing locations of gaging stations and streamflow measurement sites on the Spokane and Little Spokane Rivers, Spokane Valley-Rathdrum Prairie aquifer, Washington and Idaho

Figure 19. Graph showing daily streamflow gain on the Little Spokane River between gaging stations at Dartford $\left(0_{A D}\right)$ and near Dartford $\left(Q_{N D}\right)$ and streamflow at the gaging station at Dartford, Spokane Valley-Rathdrum Prairie aquifer, Washington and Idaho

Figure 20. Graph showing water levels in well 99 and in Long Lake, Spokane Valley-Rathdrum Prairie aquifer, Washington and Idaho

Figure 21. Graphs showing streamflow gains or losses between the various gaging stations and streamflow at the gaging station near Post Falls, Spokane Valley-Rathdrum Prairie aquifer, Washington and Idaho

Figure 22. Map showing ground-water levels for the Spokane Valley-Rathdrum Prairie aquifer, Washington and Idaho, September 2004

Figure 23. Map showing locations of monitoring wells in the Spokane Valley-Rathdrum Prairie aquifer, Washington and Idaho

Figure 24. Hydrograph showing water level in well 60 and stage on the Spokane River at the gaging station near Otis Orchards, Spokane Valley-Rathdrum Prairie aquifer, Washington and Idaho

Figure 25. Hydrograph showing water level in well 128 and stage on the Spokane River at the gaging station at Spokane, Spokane Valley-Rathdrum Prairie aquifer, Washington and Idaho

Figure 26. Hydrograph showing water levels in wells 104 and 107 and in Nine Mile Reservoir, Spokane Valley-Rathdrum Prairie aquifer, Washington and Idaho ..... 36

Figure 27. Hydrograph showing water levels in wells 92, 209, and 251, Spokane Valley-Rathdrum Prairie aquifer, Washington and Idaho

Figure 28. Hydrograph showing water levels in wells 234 and 236 and in Lake Pend Oreille, Spokane Valley-Rathdrum Prairie aquifer, Washington and Idaho 


\section{Figures-Continued}

Figure 29. Hydrograph showing water levels in wells 143 and 159 and in Coeur d'Alene Lake, Spokane Valley-Rathdrum Prairie aquifer, Washington and Idaho

Figure 30. Graph showing water levels in wells 245 and 249, Spokane Valley-Rathdrum Prairie aquifer, Washington and Idaho

Figure 31. Map showing changes in water levels, Spokane Valley-Rathdrum Prairie aquifer, Washington and Idaho, September 2004 to April 2006

Figure 32. Map showing active cells in model layer 1, Spokane Valley-Rathdrum Prairie aquifer, Washington and Idaho

Figure 33. Map showing active cells in model layer 3, Spokane Valley-Rathdrum Prairie aquifer, Washington and Idaho

Figure 34. Vertical section A-B-C-D showing how model layers represent the dividing of the aquifer from a single hydrogeologic unit into an upper and lower unit separated by a clay layer, Spokane Valley-Rathdrum Prairie aquifer, Washington and Idaho

Figure 35. Map showing sections of Spokane River used in the Streamflow-Routing Package, Spokane Valley-Rathdrum Prairie aquifer, Washington and Idaho 46

Figure 36. Graph showing relation between stage on the Spokane River at Sullivan Road Bridge ( $y$ ) and stage at the gaging station near Post Falls (x), Spokane Valley-Rathdrum Prairie aquifer, Washington and Idaho

Figure 37. Map showing horizontal hydraulic conductivity zones in model layer 1, Spokane Valley-Rathdrum Prairie aquifer, Washington and Idaho

Figure 38. Map showing hydraulic conductivity zones in model layer 2, Spokane Valley-Rathdrum Prairie aquifer, Washington and Idaho

Figure 39. Map showing horizontal hydraulic conductivity zones in model layer 3, Spokane Valley-Rathdrum Prairie aquifer, Washington and Idaho

Figure 40. Map showing specific yield zones, Spokane Valley-Rathdrum Prairie aquifer, Washington and Idaho

Figure 41. Graphs showing simulated and measured water levels in selected wells in various parts of the Spokane-Rathdrum Prairie aquifer, Washington and Idaho

Figure 42. Map showing simulated water levels in model layer 1, Spokane Valley-Rathdrum Prairie aquifer, Washington and Idaho, September 2004 ........61 61

Figure 43. Map showing simulated water levels in model layer 3, Spokane Valley-Rathdrum Prairie aquifer, Washington and Idaho, September 2004

Figure 44. Graphs showing simulated and measured monthly average streamflow gains and losses for three Spokane River segments, Spokane Valley-Rathdrum Prairie aquifer, Washington and Idaho

Figure 45. Graph showing simulated and measured monthly average streamflow gains on the Little Spokane River from the gaging stations at Dartford to near Dartford

Figure 46. Graphs showing simulated and measured streamflow gains (positive values) and losses (negative values) on various segments of the Spokane River during seepage runs of September 13-16, 2004, and August 26-31, 2005 


\section{Figures-Continued}

Figure 47. Graphs showing simulated and measured streamflow gains (positive values) and losses (negative values) on three Little Spokane River segments during seepage runs of September 13-16, 2004, and August 26-31, 2005

Figure 48. Map showing spatial distribution of weighted water-level residuals in model layer 1, September 2004, Spokane Valley-Rathdrum Prairie aquifer, Washington and Idaho

Figure 49. Graph showing weighted water-level residuals and simulated water levels $\ldots . .66$

Figure 50. Graph showing weighted flow residuals and simulated streamflow gains (positive values) or losses (negative values)

Figure 51. Map showing subregions of the Spokane Valley-Rathdrum Prairie aquifer for water-budget calculations

\section{Tables}

Table 1. Water levels in wells in and near Spirit and Hoodoo Valleys,

Bonner County, Idaho

Table 2. Estimated transmission time for precipitation infiltration to travel from base of root zone to water table, Spokane Valley-Rathdrum Prairie aquifer, Washington and Idaho

Table 3. Average volumetric rate of recharge and average recharge flux from precipitation, Spokane Valley-Rathdrum Prairie aquifer, Washington and Idaho, October 1990 through September 2005

Table 4. Drainage area and long-term average inflow to seven lakes that border the Spokane Valley-Rathdrum Prairie aquifer, Washington and Idaho

Table 5. Estimated annual withdrawals by self-supplied industries and withdrawal rates, Spokane Valley-Rathdrum Prairie aquifer, Washington and Idaho

Table 6. Streamflow measurements made on the Spokane River and some tributaries to determine streamflow gains (positive values) and losses (negative values) between measurement sites, Spokane Valley-Rathdrum Prairie aquifer, Washington and Idaho, August 26-31, 2006

Table 7. Physical data for wells in water-level monitoring network, Spokane Valley-Rathdrum Prairie aquifer, Washington and Idaho

Table 8. Model parameters, acceptable intervals, estimated values, and 95-percent confidence intervals

Table 9. Simulated 10-year average water budget for subregions of the Spokane Valley-Rathdrum Prairie aquifer 69

Table 10. Esitmated values of parameters for calibrated and alternative models $\ldots \ldots \ldots \ldots . . .71$

Table 11. Regression statistics for calibrated and alternative models .................... 72 


\section{Conversion Factors and Datums}

Conversion Factors

\begin{tabular}{lcl}
\hline Multiply & By & To obtain \\
\hline acre-foot $($ acre- $\mathrm{ft})$ & 1,233 & cubic meter $\left(\mathrm{m}^{3}\right)$ \\
cubic foot per day $\left(\mathrm{ft}^{3} / \mathrm{d}\right)$ & 0.02832 & cubic meter per day $\left(\mathrm{m}^{3} / \mathrm{d}\right)$ \\
cubic foot per second $\left(\mathrm{ft}^{3} / \mathrm{s}\right)$ & 0.02832 & cubic meter per second $\left(\mathrm{m}^{3} / \mathrm{s}\right)$ \\
foot $(\mathrm{ft})$ & 2.54 & centimeter $(\mathrm{cm})$ \\
foot per day $(\mathrm{ft} / \mathrm{d})$ & 0.3048 & meter per day $(\mathrm{m} / \mathrm{d})$ \\
foot squared per day $\left(\mathrm{ft}^{2} / \mathrm{d}\right)$ & 0.09290 & meter squared per day $\left(\mathrm{m}^{2} / \mathrm{d}\right)$ \\
inch (in.) & 2.54 & centimeter $(\mathrm{cm})$ \\
mile $(\mathrm{mi})$ & 1.609 & kilometer $(\mathrm{km})$ \\
square mile $\left(\mathrm{mi}^{2}\right)$ & 2.590 & square kilometer $\left(\mathrm{km}^{2}\right)$ \\
\hline
\end{tabular}

Temperature in degrees Celsius $\left({ }^{\circ} \mathrm{C}\right)$ may be converted to degrees Fahrenheit $\left({ }^{\circ} \mathrm{F}\right)$ as follows:

$$
{ }^{\circ} \mathrm{F}=\left(1.8 \times{ }^{\circ} \mathrm{C}\right)+32 .
$$

Temperature in degrees Fahrenheit $\left({ }^{\circ} \mathrm{F}\right)$ may be converted to degrees Celsius $\left({ }^{\circ} \mathrm{C}\right)$ as follows:

$$
{ }^{\circ} \mathrm{C}=\left({ }^{\circ} \mathrm{F}-32\right) / 1.8 .
$$

Datums

Vertical coordinate information is referenced to the North American Vertical Datum of 1988 (NAVD 88).

Horizontal coordinate information is referenced to the North American Datum of 1983 (NAD 83). Altitude, as used in this report, refers to distance above the vertical datum. 


\title{
Ground-Water Flow Model for the Spokane Valley- Rathdrum Prairie Aquifer, Spokane County, Washington, and Bonner and Kootenai Counties, Idaho
}

\author{
By Paul A. Hsieh, Michael E. Barber, Bryce A. Contor, Md. Akram Hossain, Gary S. Johnson, Joseph L. Jones, \\ and Allan H. Wylie
}

\section{Abstract}

This report presents a computer model of ground-water flow in the Spokane Valley-Rathdrum Prairie (SVRP) aquifer in Spokane County, Washington, and Bonner and Kootenai Counties, Idaho. The aquifer is the sole source of drinking water for more than 500,000 residents in the area. In response to the concerns about the impacts of increased ground-water withdrawals resulting from recent and projected urban growth, a comprehensive study was initiated by the Idaho Department of Water Resources, the Washington Department of Ecology, and the U.S. Geological Survey to improve the understanding of ground-water flow in the aquifer and of the interaction between ground water and surface water. The groundwater flow model presented in this report is one component of this comprehensive study. The primary purpose of the model is to serve as a tool for analyzing aquifer inflows and outflows, simulating the effects of future changes in groundwater withdrawals from the aquifer, and evaluating aquifer management strategies. The scale of the model and the level of detail are intended for analysis of aquifer-wide water-supply issues.

The SVRP aquifer model was developed by the Modeling Team formed within the comprehensive study. The Modeling Team consisted of staff and personnel working under contract with the Idaho Department of Water Resources, personnel working under contract with the Washington Department of Ecology, and staff of the U.S. Geological Survey. To arrive at a final model that has the endorsement of all team members, decisions on modeling approach, methodology, assumptions, and interpretations were reached by consensus.

The ground-water flow model MODFLOW-2000 was used to simulate ground-water flow in the SVPR aquifer. The finite-difference model grid consists of 172 rows, 256 columns, and 3 layers. Ground-water flow was simulated from September 1990 through September 2005 using 181 stress periods of 1 month each. The areal extent of the model encompasses an area of approximately 326 square miles. For the most part, the model extent coincides with the 2005 revised extent of the Spokane Valley-Rathdrum Prairie aquifer as defined in a previous report. However, the model excludes Spirit and Hoodoo Valleys because of uncertainties about the ground-water flow directions in those valleys and the degree of hydraulic connection between the valleys and northern Rathdrum Prairie. The SVRP aquifer is considered to be a single hydrogeologic unit except in Hillyard Trough and the Little Spokane River Arm. In those areas, a continuous clay layer divides the aquifer into an upper, unconfined unit and a lower, confined unit.

The model includes all known components of inflows to and outflows from the aquifer. Inflows to the SVRP aquifer include (1) recharge from precipitation, (2) inflows from tributary basins and adjacent uplands, (3) subsurface seepage and surface overflows from lakes that border the aquifer, (4) flow from losing segments of the Spokane River to the aquifer, (5) return percolation from irrigation, and (6) effluent from septic systems. Outflows from the SVRP aquifer include (1) ground-water withdrawals from wells, (2) flow from the aquifer to gaining segments of the Spokane River, (3) aquifer discharge to the Little Spokane River, and (4) subsurface outflow from the lower unit at the western limit of the model area near Long Lake. These inflow and outflow components are represented in the model by using MODFLOW-2000 packages.

The parameter-estimation program PEST was used to calibrate the SVRP aquifer model. PEST implements a nonlinear least-squares regression method to estimate model parameters so that the differences between measured and simulated quantities are minimized with respect to an optimal criterion. Calibration data include 1,573 measurements of water levels and 313 measurements of streamflow gains and losses along segments of the Spokane and Little Spokane Rivers. 
Model parameters estimated during calibration include hydraulic conductivity, specific yield, vertical hydraulic conductivity of riverbed sediments, and hydraulic conductance of riverbed and lakebed sediments. Simulated water levels and streamflow gains and losses generally were in good agreement with measured water level and streamflow gains and losses throughout most of the aquifer. However, discrepancies between measured and simulated quantities do occur in local parts of the aquifer. The largest discrepancy between measured and simulated water levels occurs in the lower unit in northern Hillyard Trough and the Little Spokane River Arm. These discrepancies indicate that the lower unit might not be accurately represented by the model.

After the model was calibrated, five alternative models were evaluated. In each alternative model, one aspect of the calibrated model was varied and the alternative model was re-calibrated. Results of these alternative model analyses show that changes in certain model parameter values can result in changes to certain simulated flow components even though the overall fit of the alternative model to the measured quantities is nearly as good as the calibrated model. This suggests some degree of nonuniqueness in the ground-water flow simulated by the calibrated model.

The model presented in this report is calibrated using significantly more data than are used in previous models. The relatively good fit between simulated and measured quantities indicates that the overall simulated ground-water flow is a reasonable representation of ground-water flow in the SVRP aquifer. Nonetheless, the model is subject to limitations. In particular, there is insufficient hydrologic information to determine ground-water inflow from Spirit and Hoodoo Valleys to the SVRP aquifer. In Hillyard Trough and the Little Spokane River Arm, ground-water flow in the lower unit is not well understood, and simulated water levels do not fit measured water levels as well as in other parts of the aquifer. There also is significant uncertainty in the simulated seepages from Lake Pend Oreille and Coeur d'Alene Lake. Further investigations in these parts of the SVRP aquifer could provide valuable knowledge that can be used to improve the model in the future.

\section{Introduction}

The Spokane Valley-Rathdrum Prairie (SVRP) aquifer supplies water to more than 500,000 residents in Spokane County, Washington, and Bonner and Kootenai Counties, Idaho (fig. 1). In 1978, the U.S. Environmental Protection Agency designated the aquifer as a "Sole Source Aquifer" in response to concerns about aquifer vulnerability to waterquality degradation (Federal Register, 1978). Recent and projected urban growth in the aquifer area, which includes Spokane, Spokane Valley, and Liberty Lake, Washington, and Post Falls and Coeur d'Alene, Idaho, has raised additional concerns about the effects of increased ground-water withdrawals from the aquifer. To address these concerns, a comprehensive hydrologic study was developed in 2004 by the Idaho Department of Water Resources, the Washington Department of Ecology, and the U.S. Geological Survey (USGS) to improve the understanding of ground-water flow in the aquifer and of the interaction between ground water and surface water. The purpose of the comprehensive study is to provide a scientific foundation for management of the aquifer and to provide tools that are needed to evaluate aquifer management strategies. Development of a ground-water flow model of the aquifer is one component of the comprehensive study.

The ground-water flow model presented in this report was developed by the Modeling Team formed within the comprehensive study. The Modeling Team (authors of this report) consisted of staff and personnel working under contract with the Idaho Department of Water Resources, personnel working under contract with the Washington Department of Ecology, and staff of the USGS. To arrive at a final model that has the endorsement of all team members, decisions on modeling approach, methodology, assumptions, and interpretations were reached by consensus. The Modeling Team operated under the management of the Project Technical Leadership Team and received advice and comments from the Technical Advisory Committee. In addition to undergoing the USGS report review process, the model was reviewed by the study's Peer Review Team.

\section{Purpose and Scope}

This report describes the development of a computer model to simulate ground-water flow in the SVRP aquifer. Steps in model development include: (1) defining the areal and vertical extents of the model, (2) defining boundary conditions, (3) estimating components and rates of inflows to and outflows from the aquifer, and (4) calibrating the model by adjusting model parameters (such as hydraulic conductivity and specific yield) so the differences between simulated and measured quantities (such as water levels and flows) are minimized with respect to an objective function. Model calibration uses a nonlinear least-squares regression method, which enables quantification of parameter uncertainty within the context of the regression problem.

The primary purpose of the model is to serve as a tool for analyzing SVRP aquifer inflows and outflows, simulating the effects of future changes in ground-water withdrawals from the aquifer, and evaluating aquifer management strategies. 


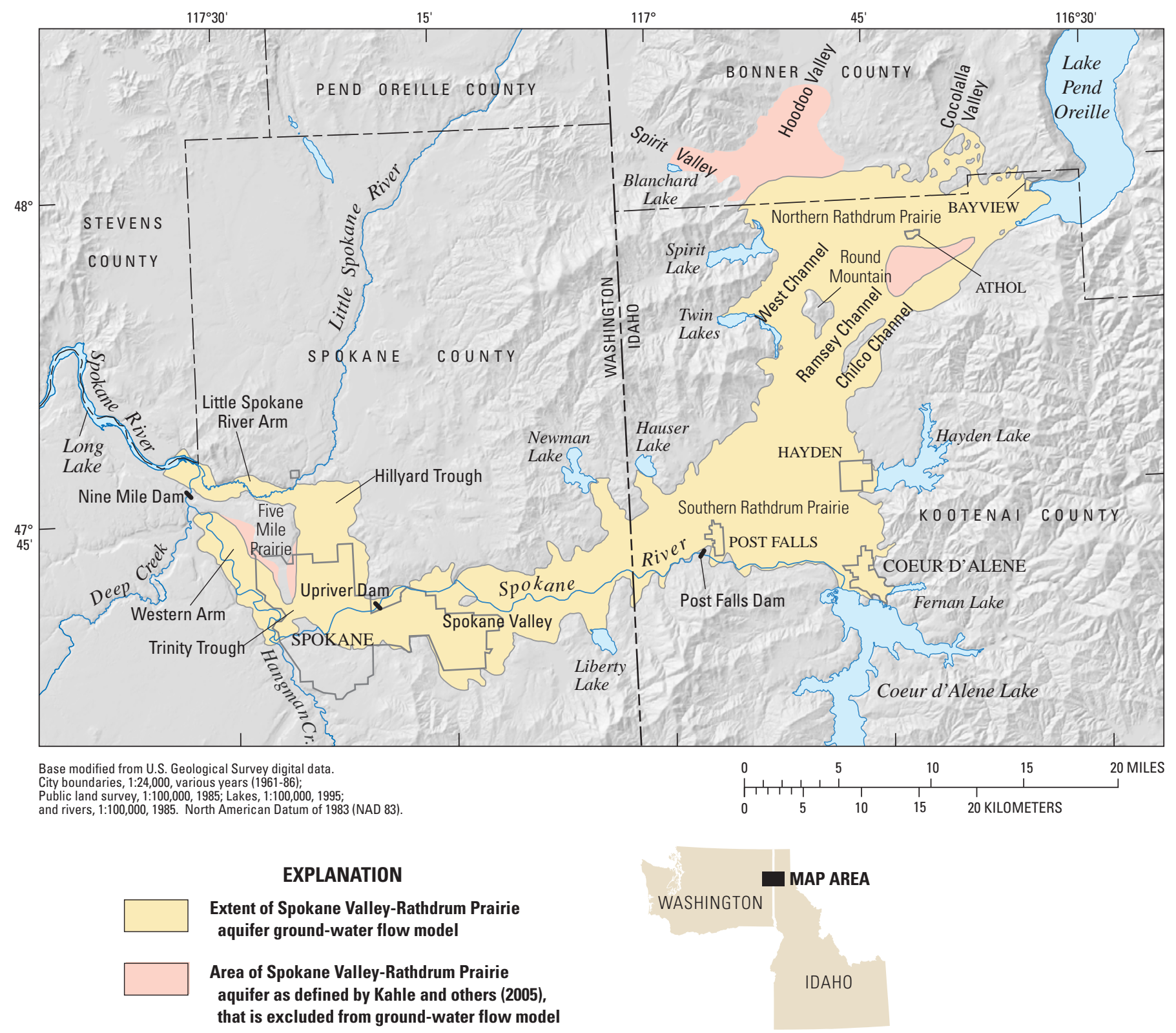

Figure 1. Location of the Spokane Valley-Rathdrum Prairie aquifer, Spokane County, Washington, and Bonner and Kootenai Counties, Idaho.

The scale of the model and the level of detail are intended for analysis of aquifer-wide water-supply issues. The model presented in this report is not intended for application to contaminant-transport issues such as the prediction of contaminant traveltimes or flow paths. A contaminanttransport model would require a substantially greater amount of hydrogeologic detail for the contamination site.

Although the areal extent of the model differs slightly from the areal extent of the SVRP aquifer as defined by Kahle and others (2005), this report does not redefine the aquifer boundary. Because of the paucity of data for the northern extreme of Rathdrum Prairie, the model does not include Spirit and Hoodoo Valleys. Ground-water flow directions in Spirit and Hoodoo Valleys and the degree of hydraulic connections between those valleys and northern Rathdrum Prairie cannot be determined with certainty with the presently available data. Therefore, during model calibration, the uncertainty in ground-water inflow from the valleys is treated by assuming different inflow values along the model boundary. 


\section{Description of Study Area}

The areal extent of the SVRP aquifer model is shown in figure 1 . The model encompasses an area of approximately $326 \mathrm{mi}^{2}$ in eastern Washington and northwestern Idaho. For the most part, the model extent coincides with the 2005 revised extent of the SVRP aquifer as defined by Kahle and others (2005). However, the model excludes Spirit and Hoodoo Valleys and three areas where bedrock is close to land surface and the aquifer sediments likely are unsaturated. Within the model extent, land-surface altitude ranges from about $2,600 \mathrm{ft}$ in northern Rathdrum Prairie to about 1,500 ft at the western limit of the model near Long Lake. The climate varies from subhumid to semiarid and is characterized by warm, dry summers and cool, moist winters. Mean annual (1971-2000) precipitation is 16.7 in. at the Spokane International Airport, Washington; 25.9 in. near Bayview, Idaho; and 28.1 in. at the Coeur d'Alene Airport, Idaho (Kahle and others, 2005, p. 6).

The SVRP aquifer is divided into several subregions by bedrock outcrops and subsurface bedrock ridges. On the east side of the aquifer, a crystalline rock outcrop known as Round Mountain and a less prominent bedrock ridge divide the aquifer into three channels that connect northern and southern Rathdrum Prairie. From west to east, these channels are known as West Channel, Ramsey Channel, and Chilco Channel. On the west side of the aquifer, two subsurface bedrock ridges extend from a basalt highland known as Five Mile Prairie. The first ridge extends to the south and the second extends to the west. The south-extending ridge, along with Five Mile Prairie, divides the aquifer into two arms. The eastern arm is known as Hillyard Trough, and the western arm is known as Western Arm. At the north end of Hillyard Trough, the aquifer continues west in the valley containing the Little Spokane River. This part of the aquifer is referred to as the Little Spokane River Arm. At the north end of Western Arm, the aquifer terminates against the subsurface bedrock ridge that extends west from Five Mile Prairie (see Kahle and others, 2005, p. 18-19). The narrow channel between Western Arm and the rest of the aquifer is known as Trinity Trough.

Nine lakes are located along the perimeter of the model area. Because the water levels of those lakes are higher than the ground-water level in the SVRP aquifer, water seeps from the lakebed and recharges the aquifer. The two largest lakes are Lake Pend Oreille and Coeur d'Alene Lake. Water levels in those lakes are regulated by dams on the respective outlet rivers. The outlet of Lake Pend Oreille is the Pend Oreille River, which is north of the area shown in the location map in figure 1. The outlet of Coeur d'Alene Lake is the Spokane River. The seven smaller lakes are Fernan Lake, Hauser Lake, Hayden Lake, Liberty Lake, Newman Lake, Twin Lakes, and Spirit Lake. These lakes do not have perennial outlet streams. However, during wet seasons, if the lake level rises above the outlet structure, lake water spills over the outlet structure and exits the lake as surface flow. Because of the highly permeable nature of the surficial and aquifer material, the surface flow soaks into the ground within a short distance of the lake.

The Spokane and Little Spokane Rivers are the major surface-water drainages in the model area. The Spokane River originates at Coeur d'Alene Lake. Water discharge from that lake is regulated by Post Falls Dam. Downstream of the dam, the Spokane River is free flowing for about 16 river miles until it reaches Upriver Pool near the Centennial Trail Bridge. Downstream of Upriver Dam, the river is again free flowing for about 4.5 river miles until it enters downtown Spokane. In the next 2.5 river miles, the river flows over basaltic rocks outside the SVRP aquifer and is regulated by dams in the Spokane Falls area. The river re-enters the aquifer at the south end of Western Arm and is again free flowing for about 10 river miles as it meanders northwest to Nine Mile Reservoir. Downstream of Nine Mile Dam, the Spokane River is joined by the Little Spokane River, which enters the model area at the north end of Hillyard Trough and flows toward the west. Downstream of the confluence of the two rivers, the Spokane River becomes a reservoir known as Long Lake, which is regulated by Long Lake Dam.

\section{Previous Investigations}

In preparation for developing the ground-water flow model presented in this report, Kahle and others (2005) compiled geologic and hydrologic information available as of June 2005 for the SVRP aquifer. The geologic information includes the pre-Tertiary, Tertiary, and Quaternary geology of the aquifer and results of previous geophysical investigations. The hydrologic information includes the current understanding of the hydrogeologic framework, ground-water movement, water-budget components, and ground-water/surface-water interactions. The compilation also includes descriptions of previous ground-water flow models by Bolke and Vaccaro (1981), CH2M Hill (1998, 2000), Buchanan (2000), and Golder Associates, Inc. (2004). In another report, Kahle and Bartolino (2007) refined the hydrogeologic understanding of the aquifer. Using drillers' records and results of available geophysical investigations, they developed a contour map showing the altitude of the base of the aquifer, mapped the extent of a clay layer in Hillyard Trough and in the Little Spokane River Arm, and updated the aquifer water budget using recently compiled information.

Because previous ground-water flow models of the SVRP aquifer are described in detail in the report by Kahle and others (2005), the following discussion highlights only the similarities and differences among the models. The models by Bolke and Vaccaro (1981), CH2M Hill (1998, 2000), and Golder Associates, Inc. (2004) encompass the western (mostly Washington) part of the aquifer from Post Falls or the IdahoWashington State line to the eastern end of Long Lake. The 
model by Buchanan (2000) encompasses the entire aquifer in both States. All four models simulate the interaction between the aquifer and the Spokane and Little Spokane Rivers.

In addition, the model by Golder Associates, Inc. (2004) simulates overland flow, river flow, and subsurface flow in the unsaturated and saturated zones of the aquifer.

Although evidence available since the late 1990s (see, for example, Gruenenfelder, 1997) indicates that an extensive clay layer divides the SVRP aquifer into an upper, unconfined unit and a lower, confined unit in Hillyard Trough and the Little Spokane River Arm, all four previous models treat the aquifer effectively as a single, unconfined, hydrogeologic unit. The clay layer is not mentioned in the reports by Bolke and Vaccaro (1981) and Buchanan (2000). In the reports by $\mathrm{CH} 2 \mathrm{M}$ Hill (1998, 2000), the clay layer is discussed but the model excludes the lower, confined unit. In the report by Golder Associates, Inc. (2004), the clay layer is treated as a geologic lens within a model layer rather than as a separate model layer. Therefore, a single model layer represents both the upper and lower units.

The four models are calibrated using different amounts of measured data for different time periods. Bolke and Vaccaro (1981) presented both a time-averaged simulation and a transient simulation for May 1977-April 1978. The model by Bolke and Vaccaro (1981) is calibrated using measured water levels in 73 wells and ground-water discharge from the SVRP aquifer to the Little Spokane River (that is, streamflow gain on the river). The calibration is checked by a water-balance calculation and by comparing simulated streamflow with measured streamflow for three sites on the Spokane River. The model by CH2M Hill $(1998,2000)$ is a steady-state model and is calibrated using measured water levels in about 110 wells and streamflow gains and losses on the Spokane River during September 1994. The calibration is checked by comparing simulated and measured water levels and streamflow gains and losses for April 1995. The model by Buchanan (2000) also is a steady-state model and is calibrated using measured water levels in 15 wells during unspecified time periods. The calibration data do not include measured streamflow gains or losses. The model by Golder Associates, Inc. (2004) is a transient model and is calibrated using measured water levels in about 20 wells and measured streamflow on the Spokane and Little Spokane Rivers during 1994, 1997, and 1999.

An important assumption in the models by Bolke and Vaccaro (1981), CH2M Hill (1998, 2000), and Golder Associates, Inc. (2004) is the boundary condition at the eastern terminus of the model. This boundary condition controls ground-water flow from Rathdrum Prairie to the model. The model by Bolke and Vaccaro (1981) specifies the hydraulic head along the eastern boundary. The calibrated model simulates a ground-water inflow of about $400 \mathrm{ft}^{3} / \mathrm{s}$ across the boundary. By contrast, the model by CH2M Hill (1998, 2000) specifies the ground-water inflow across the eastern boundary and inflow rate is adjusted during calibration. The calibrated model simulates a ground-water inflow of $385 \mathrm{ft}^{3} / \mathrm{s}$. The model by Golder Associates, Inc. (2004) specifies a timevarying hydraulic head along the eastern boundary. The report by Golder Associates, Inc. (2004, fig. 9.8) does not give the simulated flow across the boundary but does indicate that the simulated flow across the Washington-Idaho State line, about $3.5 \mathrm{mi}$ west of the eastern boundary, ranges from about 30 to $850 \mathrm{ft}^{3} / \mathrm{s}$.

Components of aquifer inflows and outflows are treated in somewhat different manners in the four models. In all four models, aquifer inflows include recharge from precipitation (that is, precipitation minus evapotranspiration), leakage from the losing segments of the Spokane River, and varying amounts of inflows from tributary basins, adjacent uplands, or lakes along the aquifer perimeter. The models by Bolke and Vaccaro (1981), CH2M Hill (1998, 2000), and Golder Associates, Inc. (2004) also include return percolation from irrigation, effluent from septic systems, and inflow across the eastern boundary as discussed in the previous paragraph. In all four models, ground water discharges to the Little Spokane River and to gaining segments of the Spokane River. The models by Bolke and Vaccaro (1981), CH2M Hill (1998, 2000), and Golder Associates, Inc. (2004) also include ground-water withdrawals by water purveyors and by industrial, commercial, agricultural, and domestic users. In the model by Bolke and Vaccaro (1981), ground-water outflow also occurs along a specified-hydraulic head boundary near the confluence of the Spokane and Little Spokane Rivers.

\section{Hydrology of Aquifer}

The geologic history and the hydrogeologic framework of the SVRP aquifer are presented in the reports by Kahle and others (2005) and Kahle and Bartolino (2007). The following discussion briefly summarizes the geologic setting of the study area. The remainder of the discussion focuses on the hydrologic information used to develop the ground-water flow model. Topics covered include the areal and vertical extent of the aquifer, hydraulic properties, inflows and outflows, interaction between the aquifer and the Spokane River, and ground-water levels and movement.

\section{Geologic Setting}

Kahle and Bartolino (2007) described three distinct hydrogeologic units in the study area: the SVRP aquifer, the Basalt and fine-grained interbeds unit, and the Bedrock unit. Together, the Basalt and fine-grained interbeds unit, which includes Columbia River basalt and interbedded lacustrine deposits of the Latah Formation, and the Bedrock unit, which includes Precambrian to Tertiary metamorphic and intrusive igneous rocks, laterally bound and underlie the SVRP aquifer. 
The SVRP aquifer consists mostly of sands, gravels, cobbles, and boulders primarily deposited by a series of catastrophic glacial outburst floods from ancient glacial Lake Missoula during the Pleistocene Epoch. Kahle and Bartolino (2007) noted that most of the aquifer sediments deposited in such a high-energy depositional environment are coarse grained. However, they also noted that fine-grained layers of clay and silt are scattered throughout the aquifer and likely were deposited in large proglacial lakes in the path of the Missoula floods. From analysis of drillers' reports, Kahle and Bartolino (2007) found that

"The aquifer generally has a greater percentage of finer material near the margins of the valley and becomes more coarse and bouldery near the center throughout the Rathdrum Prairie and Spokane Valley. In the Hillyard Trough, the deposits generally are finer grained and the aquifer consists of sand with some gravel, silt, and boulders."

\section{Areal Extent}

The areal extent of the SVRP aquifer has been redefined several times in the past 30 years. The most recent definition is the 2005 revised extent of the SVRP aquifer shown in Kahle and others (2005, pl. 2). In most places, the aquifer boundary follows the contact between the coarse, highly permeable aquifer sediments and the surrounding less permeable bedrock and fine-grained material. The 2005 revised extent includes Ramsey Channel, Chilco Channel, the south part of Hoodoo Valley, and the south part of Cocolalla Valley (fig. 1). These four areas lie outside the Sole Source Aquifer as designated by the U.S. Environmental Protection Agency in 1978. In revising the aquifer boundary, Kahle and others (2005, p. 17) noted that

"For modeling purposes, it may be important to use a more inclusive aquifer boundary to better represent contributions from adjacent surficial deposits that are in hydraulic contact with the Sole Source Aquifer."

For the most part, the extent of the model in this report coincides with the 2005 revised extent. However, the model excludes Spirit and Hoodoo Valleys and three areas where bedrock is close to land surface and the aquifer sediments likely are unsaturated (fig. 1). The model extent is not intended to be a redefinition of the aquifer. As discussed in the following paragraphs, Spirit and Hoodoo Valleys are excluded from the model because of uncertainties about the ground-water flow directions in those valleys and the degree of hydraulic connection between the valleys and northern Rathdrum Prairie.
The 2005 revised extent of the SVRP aquifer extends into the west part of Spirit Valley and the south part of Hoodoo Valley (fig. 2). Kahle and others (2005, p. 20) stated that

"In the Hoodoo Valley, historical water-level elevations indicated that a water-table divide was between Edgemere and Harlem (Walker, 1964). Ground water north of the divide moved northward toward the Pend Oreille River; ground water south of the divide moved southward toward Athol. In Spirit Valley, the ground-water divide was near Blanchard Lake (Parliman and others, 1980). West of the divide, ground water flows northwestward toward the Pend Oreille River; east of the divide, ground water flows southeastward into the main body of the SVRP aquifer."

An examination of recent water-level data and drillers' reports indicates that the previous characterization is subject to uncertainty. During the synoptic water-level measurements of September 2004 (Campbell, 2005), water levels in wells 262 and 263, at the south end of Hoodoo Valley, were several feet higher than water levels in wells 260 and 261, which are farther to the north (fig. 2, table 1). These water levels indicate that ground water flows to the north (away from northern Rathdrum Prairie) in almost the entire length of Hoodoo Valley. In Spirit Valley, water levels were measured at only one well (well 267) during September 2004. However, a search of the USGS ground-water database produced several water-level measurements for wells in the valley during the late summer of 1998 and 1999. Water levels in wells S-1, S-2, and 267 (fig. 2, table 1) indicate that the ground water flows away from the Rathdrum Prairie in almost the entire length of Spirit Valley.

Table 1. Water levels in wells in and near Spirit and Hoodoo Valleys, Bonner County, Idaho.

[Well No.: Location of wells is shown in figure 2. Abbreviations: NAVD 88, North American Vertical Datum of 1988]

\begin{tabular}{ccccc}
\hline $\begin{array}{c}\text { Well } \\
\text { No. }\end{array}$ & Well name & $\begin{array}{c}\text { U.S. Geological } \\
\text { Survey } \\
\text { site No. }\end{array}$ & $\begin{array}{c}\text { Date of } \\
\text { water-level } \\
\text { measurement }\end{array}$ & $\begin{array}{c}\text { Altitude of } \\
\text { water level, } \\
\text { in feet above } \\
\text { NAVD 88 }\end{array}$ \\
\hline 260 & 54N 04W 10BBA1 & 480300116492401 & $09-16-2004$ & $2,148.52$ \\
261 & 54N 04W 10DCD1 & 480209116484201 & $09-16-2004$ & $2,147.45$ \\
262 & 54N 04W 19BCD1 & 480051116532101 & $09-16-2004$ & $2,158.17$ \\
263 & 54N 04W 29ABC1 & 480015116512901 & $09-16-2004$ & 2,151 \\
264 & 54N 04W 30BAB1 & 480021116531201 & $09-16-2004$ & $2,044.18$ \\
266 & 54N 04W 31BCB1 & 475849116521601 & $09-16-2004$ & $2,035.78$ \\
S-1 & 54N 05W 23DBA1 & 480046116552201 & $09-15-1999$ & 2,214 \\
267 & 54N 05W 22ACA1 & 480101116563601 & $08-06-1998$ & 2,190 \\
S-2 & 54N 05W 18AAA1 & 480207117001401 & $09-23-1998$ & 2,185 \\
& & & $09-20-1999$ & 2,189 \\
\hline
\end{tabular}




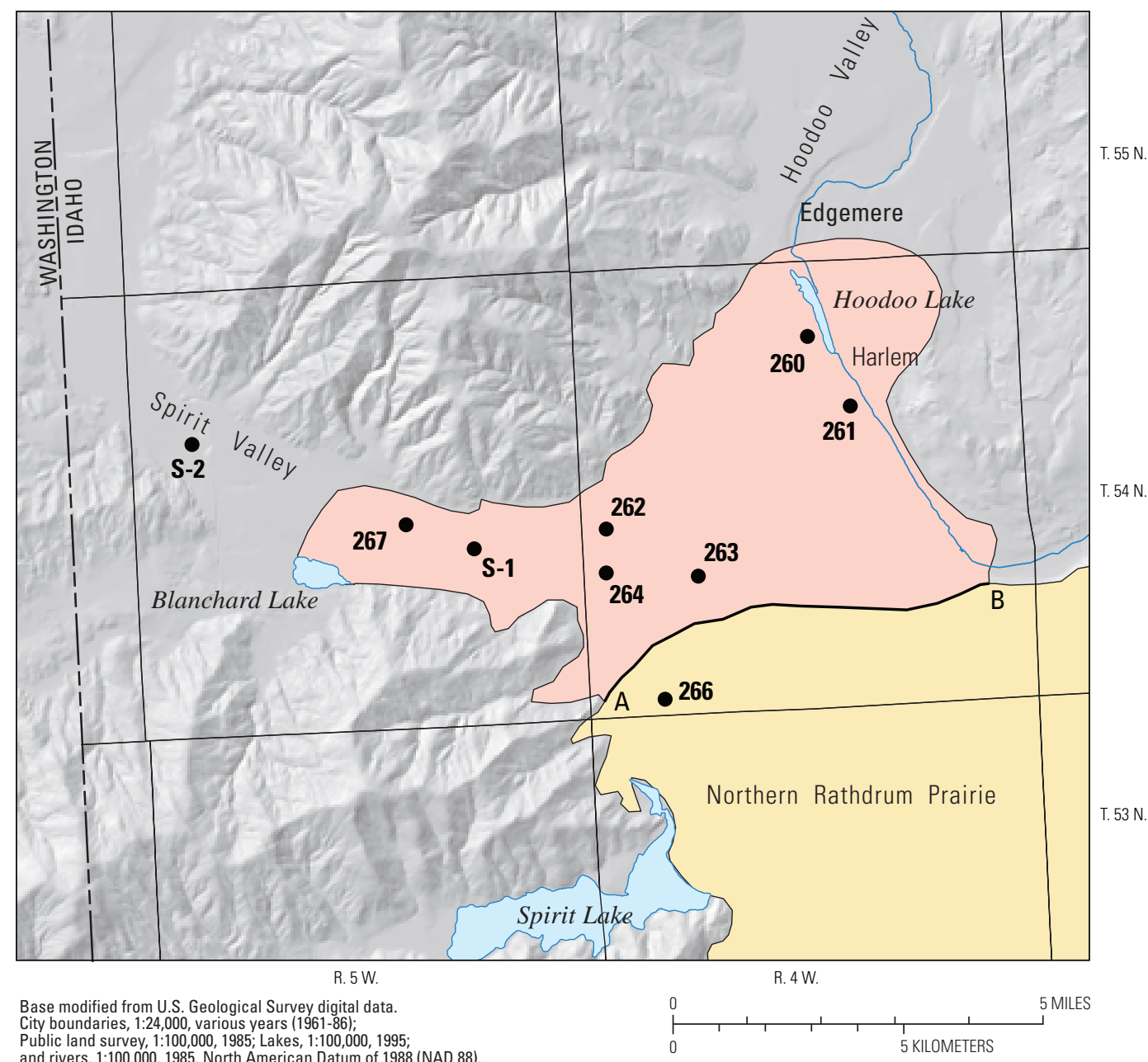

EXPLANATION

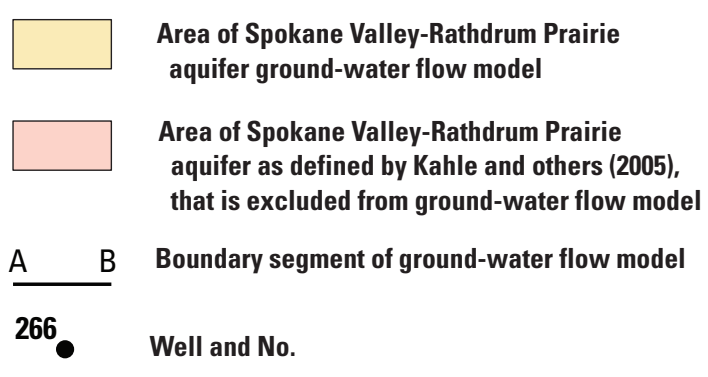

Figure 2. Locations of wells in and near Spirit and Hoodoo Valleys, Bonner County, Idaho.

The synoptic water-level measurements of September 2004 (Campbell, 2005) also show a water-level difference of about $100 \mathrm{ft}$ over a relatively short distance of about $1 \mathrm{mi}$ from the south end of Hoodoo Valley to northern Rathdrum Prairie. Water levels in wells 262 and 263 were 2,158.17 and 2,151 ft, respectively. Water levels in wells 264 and 266 were 2,044.18 and 2,035.78 ft, respectively. Drillers' reports for T. $54 \mathrm{~N}$., R. 4 W. and the north half of T. 53 N., R. 4 W. show a similar water-level difference from the south end of Hoodoo Valley to northern Rathdrum Prairie. The relatively large water-level difference over a relatively short distance can indicate the presence of a low hydraulic conductivity barrier resulting in a poor hydraulic connection between Hoodoo Valley and northern Rathdrum Prairie. However, although clay layers are noted in some drillers' reports for the area, conclusive evidence of a low hydraulic conductivity barrier is lacking. 
Considered together, available data indicate uncertainty in ground-water flow directions in Spirit and Hoodoo Valleys and in the degree of hydraulic connection between those valleys and northern Rathdrum Prairie. Because of this uncertainty, the model in this report terminates at boundary segment A-B (fig. 2) and does not extend into Spirit and Hoodoo Valleys. If ground-water inflow from these valleys to northern Rathdrum Prairie does occur, the inflow is assumed to be negligible. During model calibration, the uncertainty in ground-water inflow from Spirit and Hoodoo Valleys is treated by assuming different inflow values along boundary segment A-B.

In addition to Spirit and Hoodoo Valleys, three areas in the 2005 revised extent are excluded from the model (fig. 1). The first excluded area is on the east side of northern Rathdrum Prairie. Hydrogeologic sections $L-L^{\prime}$ and $0-0^{\prime}$ in Kahle and Bartolino (2007, pl. 2) indicate that bedrock is close to land surface in this area and the aquifer sediments likely are unsaturated. The second and third excluded areas are two narrow zones that border Five Mile Prairie and the subsurface bedrock ridge that extends from the prairie toward the south. The aquifer sediments in the two narrow zones likely also are unsaturated as they lie on the slope of the basalt that outcrops to form Five Mile Prairie.

\section{Vertical Extent}

The sediments of the SVRP aquifer extend from land surface downward to either bedrock or the Latah Formation, which is composed predominantly of lacustrine and fluvial deposits of siltstone, claystone, and minor sandstone. The altitude of the base of the aquifer as determined by Kahle and Bartolino (2007) is shown in figure 3. Sediment thickness

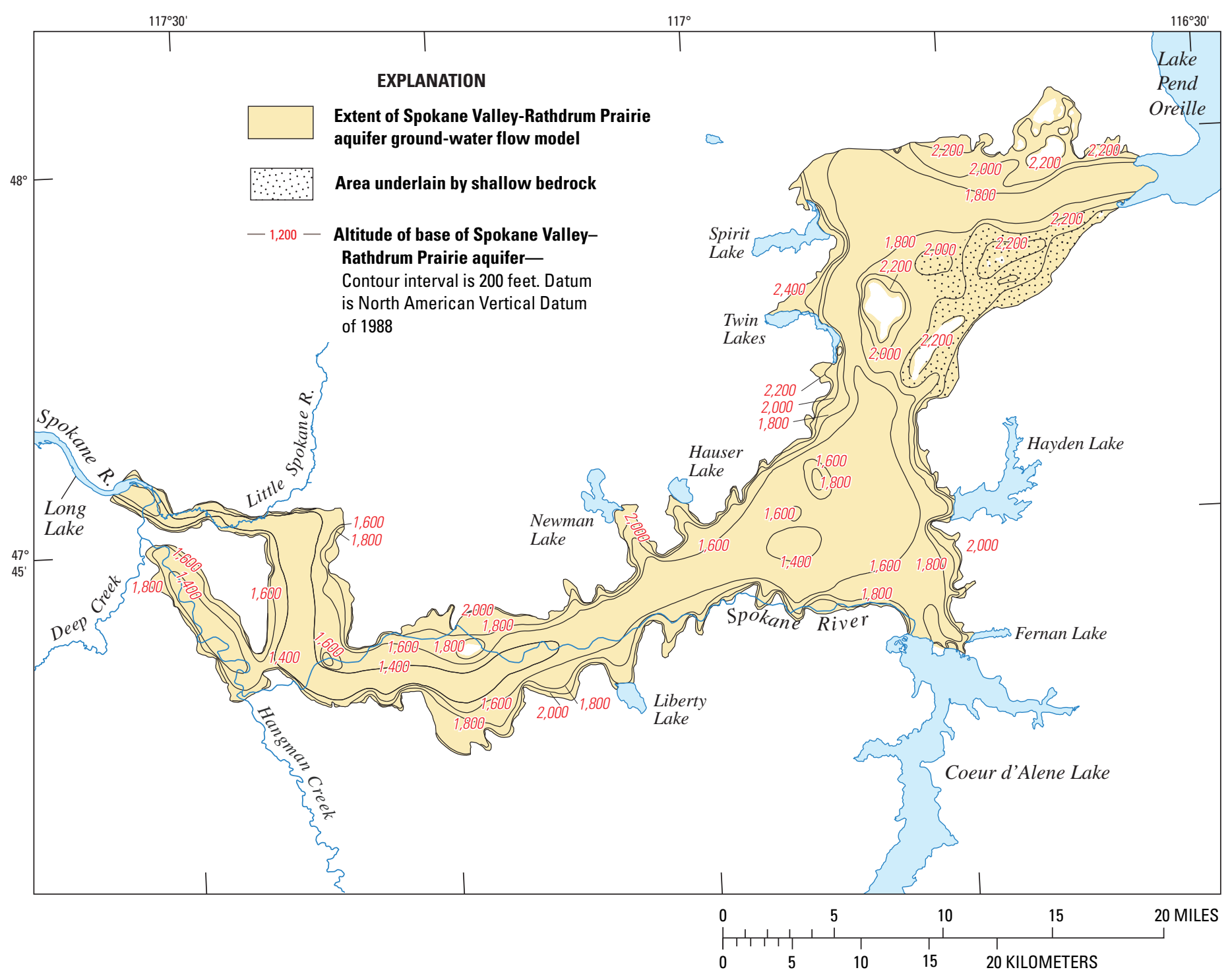

Figure 3. Approximate altitude of the base of the Spokane Valley-Rathdrum Prairie aquifer, Spokane County, Washington, and Bonner and Kootenai Counties, Idaho. 
(from land surface to the base of the aquifer) is largest in the central part of the aquifer and thins to zero at the aquifer perimeter. The maximum sediment thickness is about $800 \mathrm{ft}$ in northern Rathdrum Prairie, $500 \mathrm{ft}$ near the WashingtonIdaho State line, and $700 \mathrm{ft}$ in Hillyard Trough. However, the saturated thickness (from the water table to the base of the aquifer) can be substantially less than the sediment thickness. For example, in northern Rathdrum Prairie, the depth from the land surface to the water table can exceed $500 \mathrm{ft}$, and the maximum saturated thickness is between 200 and $300 \mathrm{ft}$. In the area underlain by shallow bedrock (fig. 3) the saturated zone likely is a thin veneer overlying the bedrock or is entirely absent.

The SVRP aquifer is considered to be a single hydrogeologic unit except in Hillyard Trough and the Little Spokane River Arm. In those areas, a continuous clay layer divides the aquifer into an upper unconfined unit and a lower confined unit. Kahle and Bartolino (2007) characterize this clay layer as a "fine-grained layer." However, the term "clay layer" is used in this report to emphasize the low-permeability character of the layer. The areal extent of the clay layer as mapped by Kahle and Bartolino (2007) is shown in figure 4.
The vertical extent of the clay layer is shown in hydrogeologic section $C-C^{\prime}$ in figure 5. According to Kahle and Bartolino (2007), the average thickness of the clay layer is $215 \mathrm{ft}$ in Hillyard Trough and $130 \mathrm{ft}$ in the Little Spokane River Arm. In Hillyard Trough, the altitude of the top of the clay layer is between 1,660 and 1,720 ft. In the Little Spokane River Arm, the altitude of the top of the clay layer is between 1,500 and $1,700 \mathrm{ft}$.

\section{Hydraulic Properties}

The SVRP aquifer is a highly productive aquifer. Wells in the aquifer yield as much as several thousand gallons per minute with relatively little drawdown. Many wells penetrate only the upper part (less than $100 \mathrm{ft}$ ) of the aquifer's saturated thickness. Kahle and others (2005, p. 19-20) noted that hydraulic conductivity of the aquifer sediments is at the upper end of values measured in the natural environment. However, the aquifer also contains local zones of less permeable, finegrained sedimentary materials.

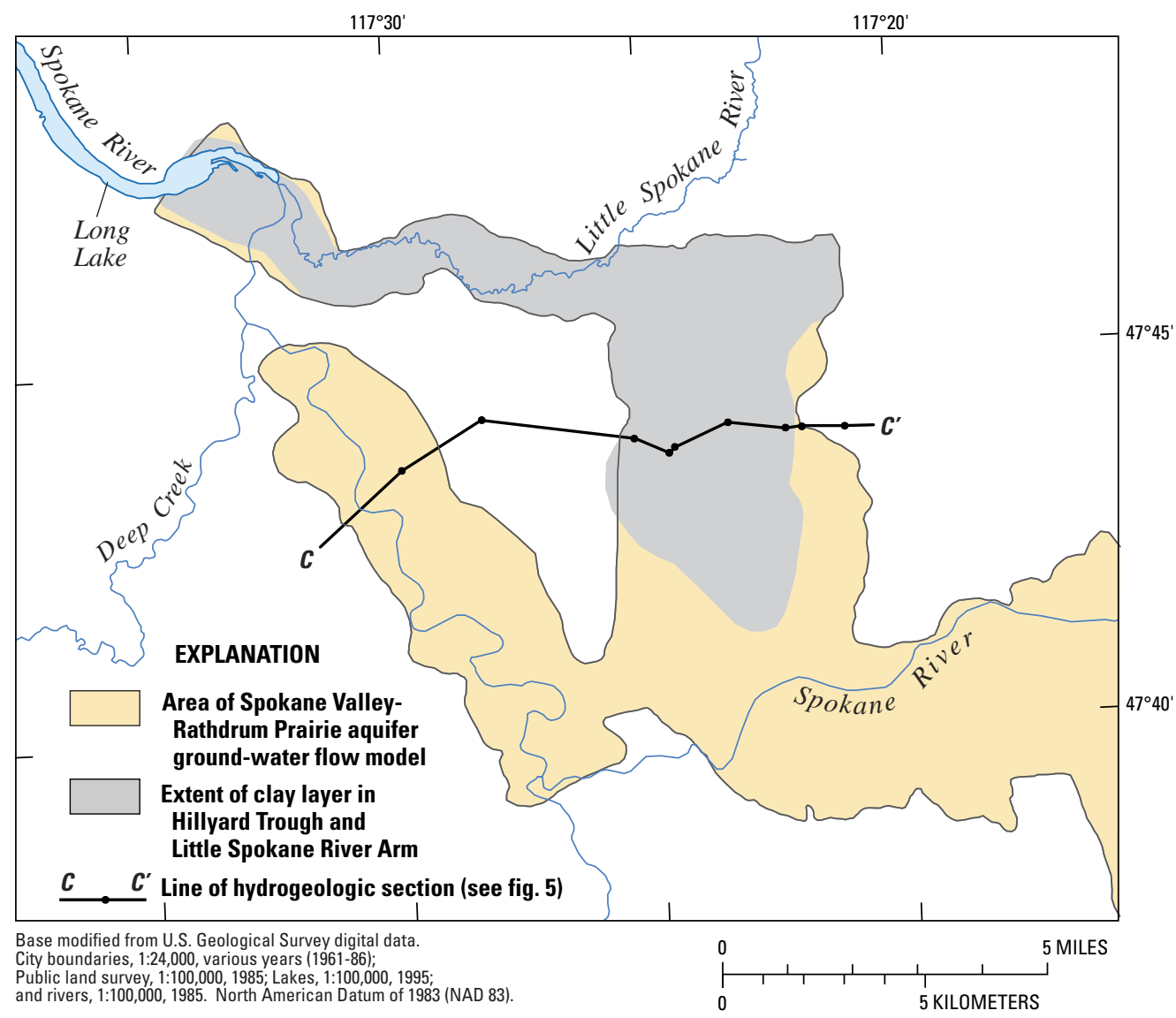

Figure 4. Areal extent of clay layer in Hillyard Trough and the Little Spokane River Arm, Spokane County, Washington. 

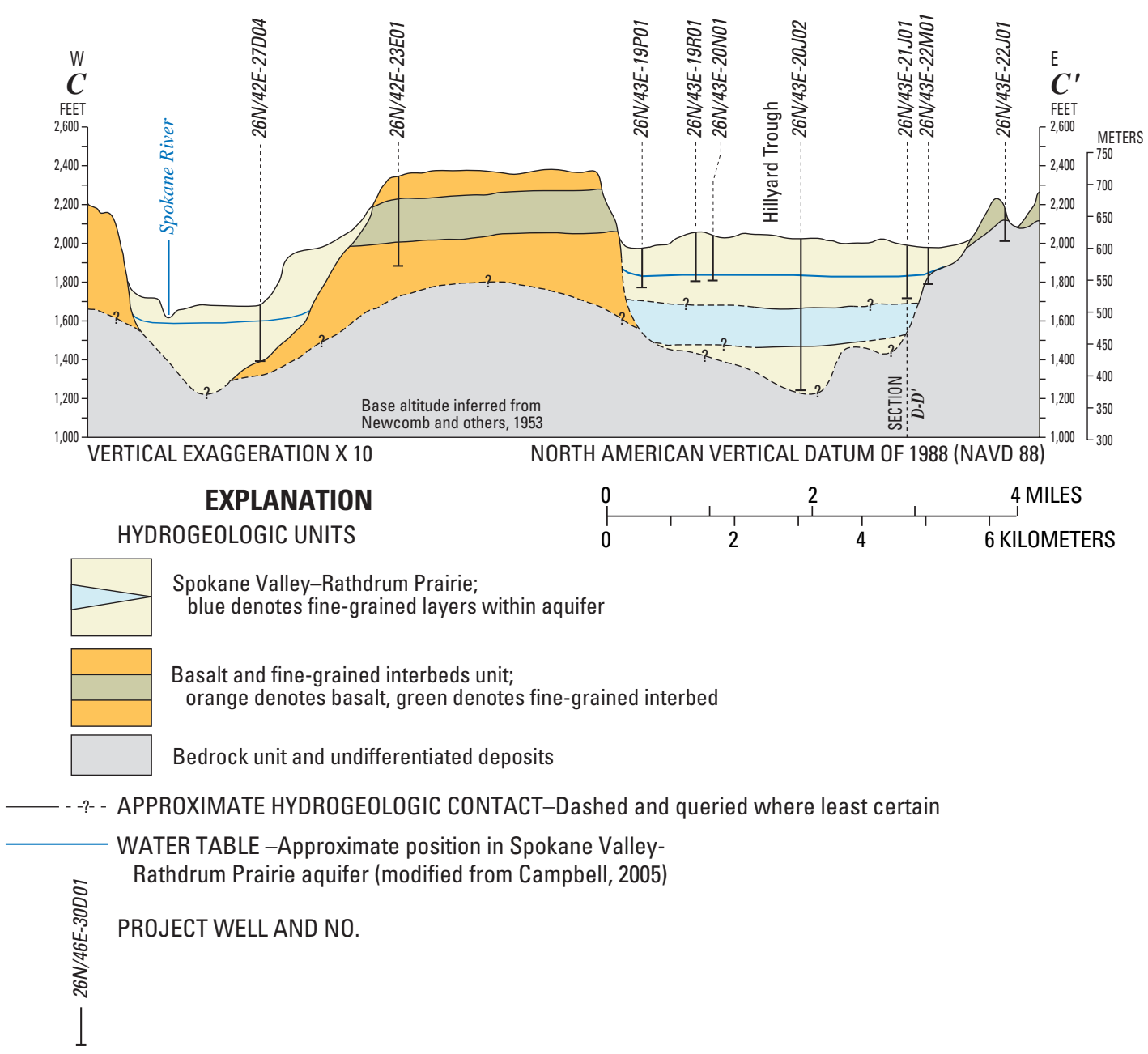

Figure 5. Generalized hydrogeologic section of the Spokane Valley-Rathdrum Prairie aquifer along hydrogeologic section C-C' (from Kahle and Bartolino, 2007).

\section{Horizontal Hydraulic Conductivity}

Multiple-well aquifer tests, specific-capacity data, and computer model analyses have been used in previous studies to estimate the horizontal hydraulic conductivity $\left(\mathrm{K}_{h}\right)$ of the SVRP aquifer. Aquifer tests and specific capacity data are more numerous in more populated regions of the SVRP aquifer-from the city of Spokane, Washington, on the west to Post Falls and Coeur d'Alene, Idaho, on the east. There is significantly less information on hydraulic properties in Rathdrum Prairie north of Post Falls and Coeur d'Alene.

Data for nine multiple-well aquifer tests conducted in the west half of the SVRP aquifer (fig. 6) are given by $\mathrm{CH} 2 \mathrm{M}$ Hill
$(1998,2000)$. These data appear to be the only multiple-well aquifer-test data readily available from published sources. Estimated $\mathrm{K}_{h}$ values given in the reports range from 500 to 6,200 ft/d (CH2M Hill, 1998, p. 2-22 and tables 2-7; CH2M Hill, 2000, table E-2). However, analyses of the tests are complicated by the fact that the pumped and observation wells do not penetrate the entire thickness of the aquifer.

Specific capacity is the ratio of pumping rate to drawdown in a well after a given pumping duration. However, there is no commonly accepted pumping duration and it can be highly variable from one test to the next. Consequently, $\mathrm{K}_{\mathrm{h}}$ values estimated from specific-capacity data are not as reliable as values estimated from multiple-well aquifer-test data. 


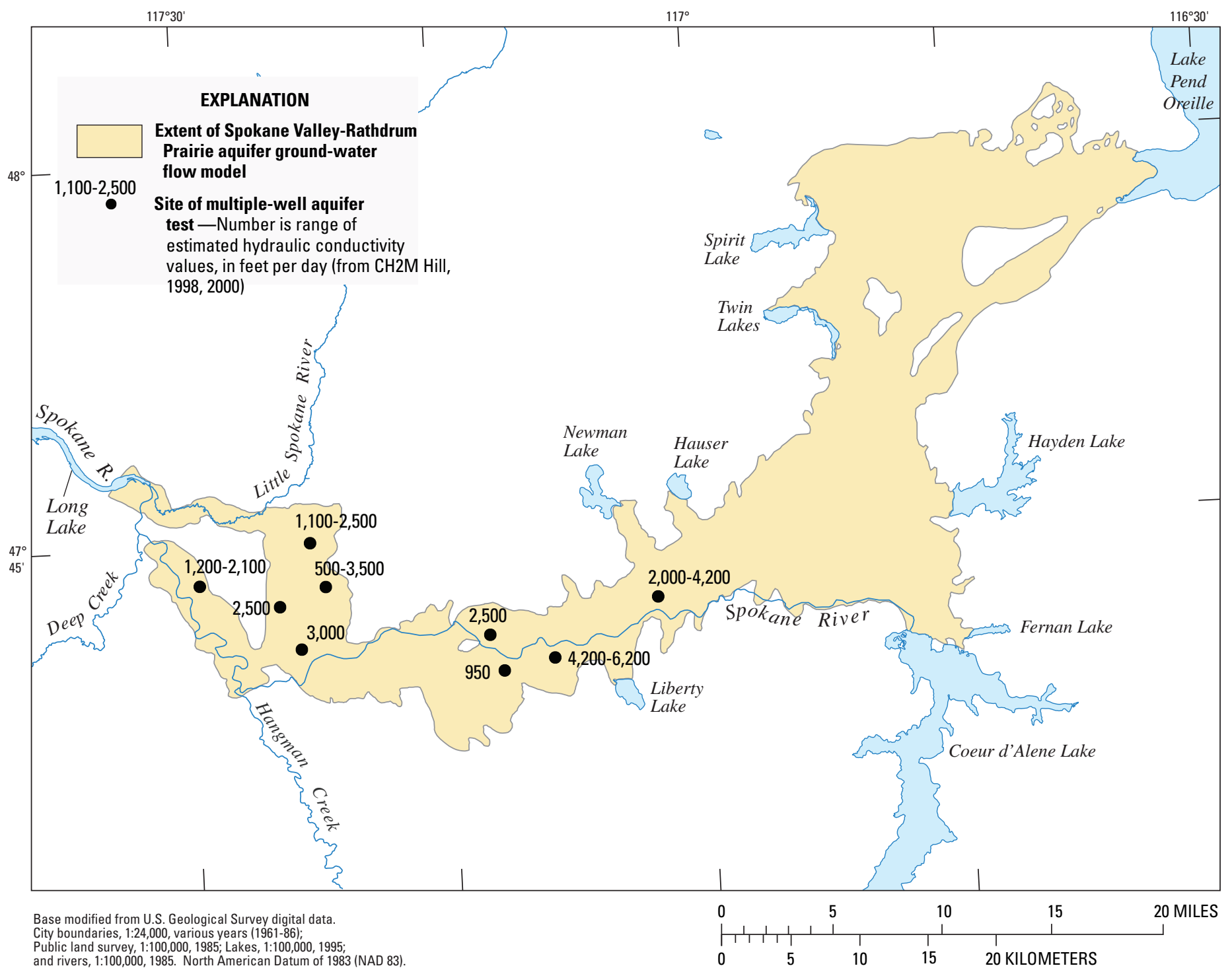

Figure 6. Locations of multiple-well aquifer-test sites in the west half of the Spokane Valley-Rathdrum Prairie aquifer, Washington and Idaho.

Sagstad (1977), Bolke and Vaccaro (1981), and CH2M Hill (1998) estimated $K_{h}$ from single-well specific capacity data. Bolke and Vaccaro (1981, p. 18) indicated a decrease in $\mathrm{K}_{\mathrm{h}}$ values in a westerly direction from the Post Falls area. They stated:

"The decrease in values in the down-valley direction is indicative of the change in valley-fill material, which, in general grades from coarse to fine in a westerly direction."

The estimated $K_{h}$ values given by Bolke and Vaccaro (1981) average about 6,000 ft/d in the Post Falls area, about 4,300 ft/d in Spokane Valley, about 2,600 ft/d near Spokane, and about $860 \mathrm{ft} / \mathrm{d}$ in Hillyard Trough and the Little Spokane River Arm.
CH2M Hill (1998, p. 2-24 and tables 2-8) indicated that $K_{h}$ values estimated from analysis of 31 specific capacity tests range from 100 to $6,200 \mathrm{ft} / \mathrm{d}$ for the west half of the SVRP aquifer. The central 50 percent of the values range from 400 to 3,000 ft/d. However, CH2M Hill (1998) also noted that

"For many wells, including those closest to the State line, the computed transmissivities [horizontal hydraulic conductivity times saturated thickness] appear to underestimate the likely aquifer transmissivity because the wells pump at low rates or are shallow (for example, they penetrate only a very small fraction of the aquifer's saturated thickness)." 
In a hydrogeologic study of southern Rathdrum Prairie, Sagstad (1977, p. 39-40) analyzed specific-capacity data for 20 wells in the Post Falls area and 4 wells in the Coeur d'Alene area. The estimated $K_{h}$ values given by Sagstad (1977) range from 250 to 2,100 ft/d in the Post Falls area and from 240 to $900 \mathrm{ft} / \mathrm{d}$ in the Coeur d'Alene area. Sagstad noted that

"Transmissive characteristics in the Post Falls area generally are higher than in the Coeur d'Alene area. Well logs show that greater percentages of coarse gravels, pebbles, and sands are present in the Post Falls area than in the Coeur d'Alene area."

This characterization is consistent with a steeper water-table gradient in the Coeur d'Alene area than in the Post Falls area, as shown by the ground-water level map of Campbell (2005).

Horizontal hydraulic conductivity values used in previous computer models generally were higher than values estimated from multiple-well aquifer tests and specific-capacity data. In the model by Bolke and Vaccaro (1981, p. 20), $K_{h}$ values ranged from about 1,000 to $11,000 \mathrm{ft} / \mathrm{d}$. These values result from an upward adjustment, by a factor of 1.9, of the initial values estimated from specific-capacity data. In the final model of CH2M Hill (2000, fig. J-4), $\mathrm{K}_{\mathrm{h}}$ values ranged from 2,000 ft/d in northern Hillyard Trough to 7,000 ft/d at the Idaho-Washington State line. In the model by Golder Associates, Inc. (2004, fig. 6.8), $\mathrm{K}_{\mathrm{h}}$ values ranged from about $260 \mathrm{ft} / \mathrm{d}$ in northern Hillyard Trough to about 57,000 ft/d at the Idaho-Washington State line.

The model by Buchanan (2000) is the only previous model that encompasses the entire SVRP aquifer. In that model, on the east side of the aquifer, a zone that has a $\mathrm{K}_{\mathrm{h}}$ value of 11,000 ft/d extends from Lake Pend Oreille toward the west through northern Rathdrum Prairie and then toward the south through West Channel into southern Rathdrum Prairie. Lower $K_{h}$ values (220 ft/d or less) are assigned to areas near the aquifer perimeter and in side valleys. This characterization is consistent with the steeper water-table gradients in side valleys in which Hauser, Hayden, Newman, and Spirit Lakes are located (see water-level map of Campbell, 2005). On the west side of the aquifer, $K_{h}$ values are similar to those in the CH2M Hill (2000) model.

Considered together, available data indicate that $\mathrm{K}_{h}$ values in the central part of the SVRP aquifer range from about 1,000 $\mathrm{ft} / \mathrm{d}$ to several tens of thousands of feet per day. In Hillyard Trough and in the vicinity of Coeur d'Alene, $K_{h}$ values appear to be near the low end of the range. Near the aquifer perimeter and in side valleys, $K_{h}$ values might be a few hundred feet per day or less.

\section{Vertical Hydraulic Conductivity}

Few field-measured vertical hydraulic conductivity $\left(K_{v}\right)$ data were available for the SVRP aquifer and for the clay layer that separates the upper and lower aquifer units in Hillyard
Trough and the Little Spokane River Arm. In the models by CH2M Hill (1998, 2000) and Golder Associates, Inc. (2004), the ratio of $K_{h}$ to $K_{v}$ in the aquifer was assumed to be 10:1 and 3:1, respectively. The report by Golder Associates, Inc. (2003, p. 5-24) refers to an aquifer test conducted near the Colbert Landfill (about $10 \mathrm{mi}$ north of Spokane) where a clay layer separates an upper aquifer from a lower aquifer. Both the clay layer in Hillyard Trough and the clay layer near the Colbert Landfill are believed to have been deposited within a glacial lake environment. Golder Associates, Inc. (2003, p. 5-24) noted that

"During pump tests at wells near the Colbert Landfill (Landau Associates, 1991) no response in the upper sands and gravels was observed during pumping from the lower sands and gravels, indicating that the glacial lake sediments act as a vertical hydraulic barrier between the upper and lower sand and gravel units in this area."

However, it is uncertain if this characterization also applies to the clay layer in Hillyard Trough and the Little Spokane River Arm.

\section{Specific Yield}

Few field-measured specific yield $\left(S_{Y}\right)$ data were available for the SVRP aquifer. In the model by Bolke and Vaccaro (1981), $S_{Y}$ values initially were estimated from published tables that relate $S_{Y}$ to grain size and subsequently adjusted during model calibration. Values of $S_{Y}$ in the calibrated model ranged from about 0.1 to 0.2 . In the model by Golder Associates, Inc. (2004, fig. 6-8), a similar procedure yielded $\mathrm{S}_{\mathrm{Y}}$ values that ranged from 0.125 to 0.3 . The models by $\mathrm{CH} 2 \mathrm{M}$ Hill $(1998,2000)$ and Buchanan $(2000)$ do not consider $S_{Y}$ because those models assume steady-state flow conditions.

\section{Inflows to Aquifer}

Inflows to the SVRP aquifer include (1) recharge from precipitation, (2) inflows from tributary basins and adjacent uplands, (3) subsurface seepage and surface overflows from lakes that border the aquifer, (4) flow from losing segments of the Spokane River to the aquifer, (5) return percolation from irrigation, and (6) effluent from septic systems. For the ground-water flow model in this report, monthly inflows were estimated for October 1990 through September 2005. Areally distributed inflow components, such as recharge from precipitation, are computed on a raster grid with a cell size of 1,320 by $1,320 \mathrm{ft}$. To facilitate preparation of model input data, the raster grid is aligned with the finite-difference grid used in the model. 


\section{Precipitation}

Recharge from precipitation refers to that part of precipitation that infiltrates into the subsurface and percolates downward to reach the water table. Precipitation can enter the subsurface by falling on a permeable surface and infiltrating into the ground or falling on an impermeable (paved) surface and running off to a recharge ("dry") well, an infiltration basin, or an adjacent permeable surface. In both cases, part of the precipitation is consumed by evapotranspiration, either on land surface or as the water percolates through the root zone (typically, the top several feet of subsurface). The water that percolates below the root zone is referred to as deep percolation. The assumption is that evapotranspiration does not occur below the root zone, and water that becomes deep percolation eventually reaches the water table.

If precipitation falls on a permeable surface within the SVRP aquifer, the entire amount of precipitation is assumed to enter the ground and there is no overland runoff. This assumption is reasonable for the SVRP aquifer because the aquifer material is highly permeable. The monthly rate of deep percolation resulting from precipitation on a permeable surface is denoted by $D_{p}$ and is expressed in units of length over time-for example, inches per month.

To estimate $D_{p}$, the FAO Penman-Monteith method developed by Allen and others (1998) was used to estimate evapotranspiration. Bartolino (2007) used the method to estimate daily evapotranspiration for 1990-2005 at six weather stations in the vicinity of the model area (fig. 7). Daily deep percolation at each weather station was determined from a daily soil-moisture balance calculation (Bartolino, 2007, p. 11, eq. 19). The daily deep percolation values then were aggregated over each month to determine the $D_{p}$ value for each weather station.

The areal distribution of $D_{p}$ is estimated by linearly interpolating the $D_{p}$ values for the six weather stations. To perform the interpolation, an initial triangular network is constructed using the six weather stations as vertices. However, this initial network does not encompass the full extent of the model. Therefore, three auxiliary vertices are added to expand the network (fig. 7). The $D_{p}$ at an auxiliary vertex is set equal to the $D_{p}$ at the closest weather station. For any point within the expanded network, $D_{p}$ is interpolated linearly from the $D_{p}$ values for the three vertices of the triangle containing the point.

If precipitation falls on an impermeable surface and then runs off to a recharge well, an infiltration basin, or an adjacent permeable surface, the assumption is that 15 percent of the runoff is consumed by evapotranspiration and the remaining 85 percent becomes deep percolation. Because infiltration is focused into the recharge well, infiltration basin, or along the edges of the adjacent permeable surface, loss to evapotranspiration probably is relatively low. The monthly rate of deep percolation resulting from precipitation on an impermeable surface is denoted by $D_{1}$.

Two data sets are used to estimate the areal distribution of $D_{1}$. The first contains values for the amount of impermeable surface in the model area, and the second contains values for precipitation throughout the model area. The amount of impermeable surface is estimated from aerial photographs and National Land-Cover Data (http://erg.usgs.gov/isb/pubs/ factsheets/fs 10800.html) for four periods: 1990-95, 1996-99, 2000-02, and 2002-05. Within each period, the amount of impermeable surface is assumed to remain constant in time. Precipitation throughout the model area is obtained from PRISM-derived data. PRISM is an acronym for "Parameterelevation Regressions on Independent Slopes Model" and was developed by the Oregon Climate Service of Oregon State University (http://www.ocs.orst.edu/prism/products/). PRISM uses point data, a digital elevation model, and other spatial data sets to generate gridded estimates of several spatial and temporal climatic parameters, including precipitation.

The areal distribution of $D_{1}$ is calculated on a raster grid with a cell size of 1,320 by $1,320 \mathrm{ft}$. For each cell in the grid, $D_{1}$ is calculated as

$$
D_{1}=P \times f_{1} \times 0.85,
$$

where

$\mathrm{P}$ is the monthly precipitation rate, and

$f_{1}$ is the fraction of the cell's surface area that is impermeable.

Runoff from impermeable surfaces in certain parts of Spokane and Coeur d'Alene where the runoff is routed into a sewer overflow system that discharges to the Spokane River was excluded from the calculation.

Combining $D_{p}$ and $D_{1}$, the monthly rate of deep percolation (D) at a cell is calculated as

$$
D=\left(1-f_{1}\right) D_{p}+D_{1}
$$

Note that for any given month, $\mathrm{D}$ is the downward flux at the base of the root zone. This downward infiltration must travel through the unsaturated zone to reach the water table. According to unsaturated flow theory, the transmission time of an infiltration front to a given depth depends on the prevailing moisture conditions in the unsaturated zone. In this study, a simple approximation is adopted in which the traveltime to the water table is linearly related to the depth of the water table.

To estimate the transmission time to the water table, water levels recorded at well 251 are compared to the monthly rates of deep percolation (D) for the well site (fig. 8). Well 251 is selected for analysis because the water level in the well is 


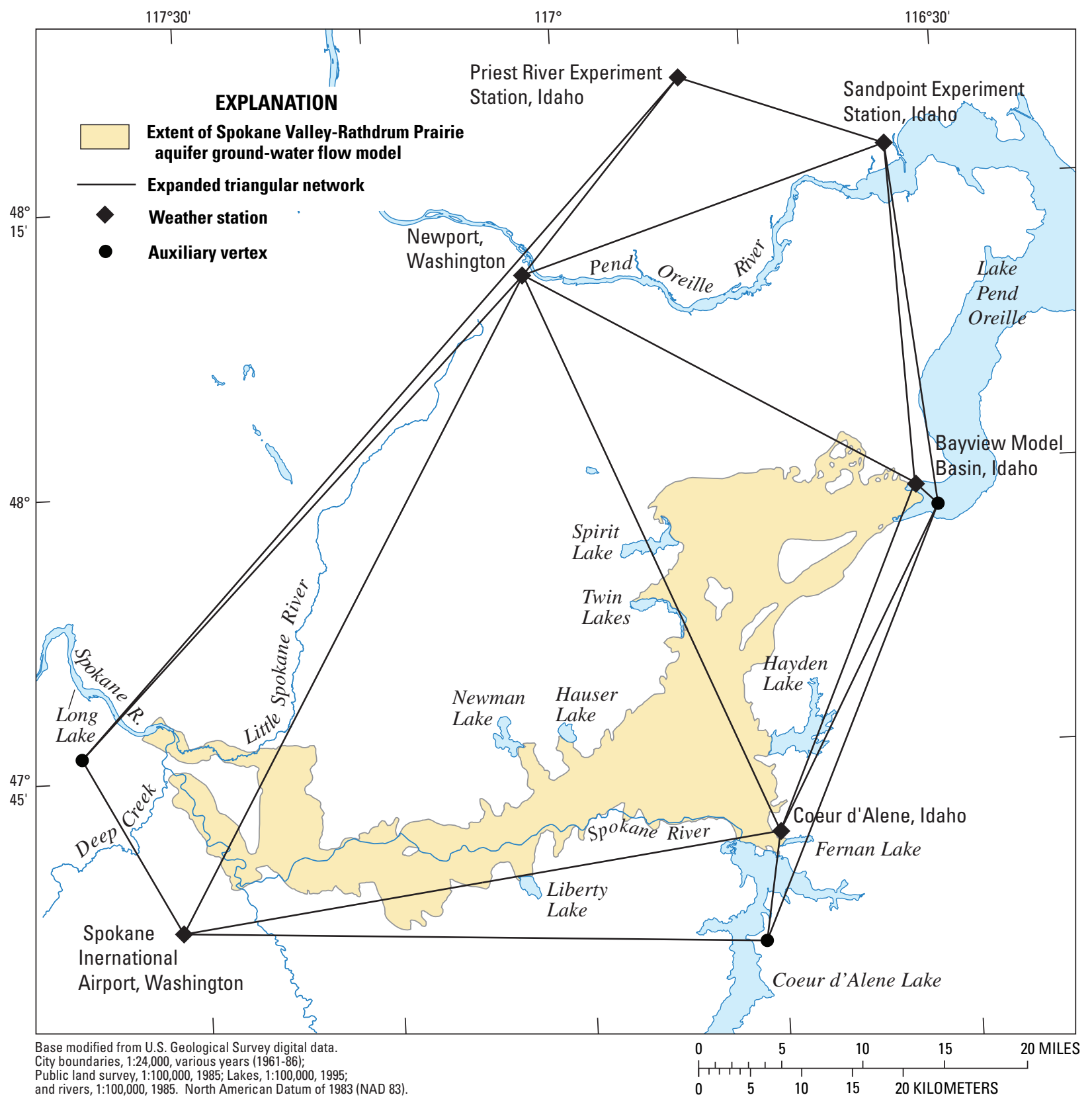

Figure 7. Locations of weather stations, auxiliary vertices, and expanded triangular network used for interpolation of recharge from precipitation on permeable surfaces, Spokane Valley-Rathdrum Prairie aquifer, Washington and Idaho.

about $400 \mathrm{ft}$ below land surface and the well has a long period of record. For each water year during which the hydrograph peak and trough are not masked by the long-term trend, the point of steepest water-level rise, assumed to be approximately halfway between the trough and the peak, is indicated by a triangle on the graph. The time of steepest water-level rise is assumed to correspond to the time of greatest recharge at the water table. The steepest water level rise typically occurs around May (fig. 8). However, deep percolation at the base of the root zone is greatest around the preceding December or early January. This observation indicates a transmission time of about 5 months is needed for precipitation infiltration to reach the water table at a depth of about $400 \mathrm{ft}$. The estimated transmission time to reach the water table at different depths, based on linearly prorating the transmission time to the depth of $400 \mathrm{ft}$, is shown in table 2 . 


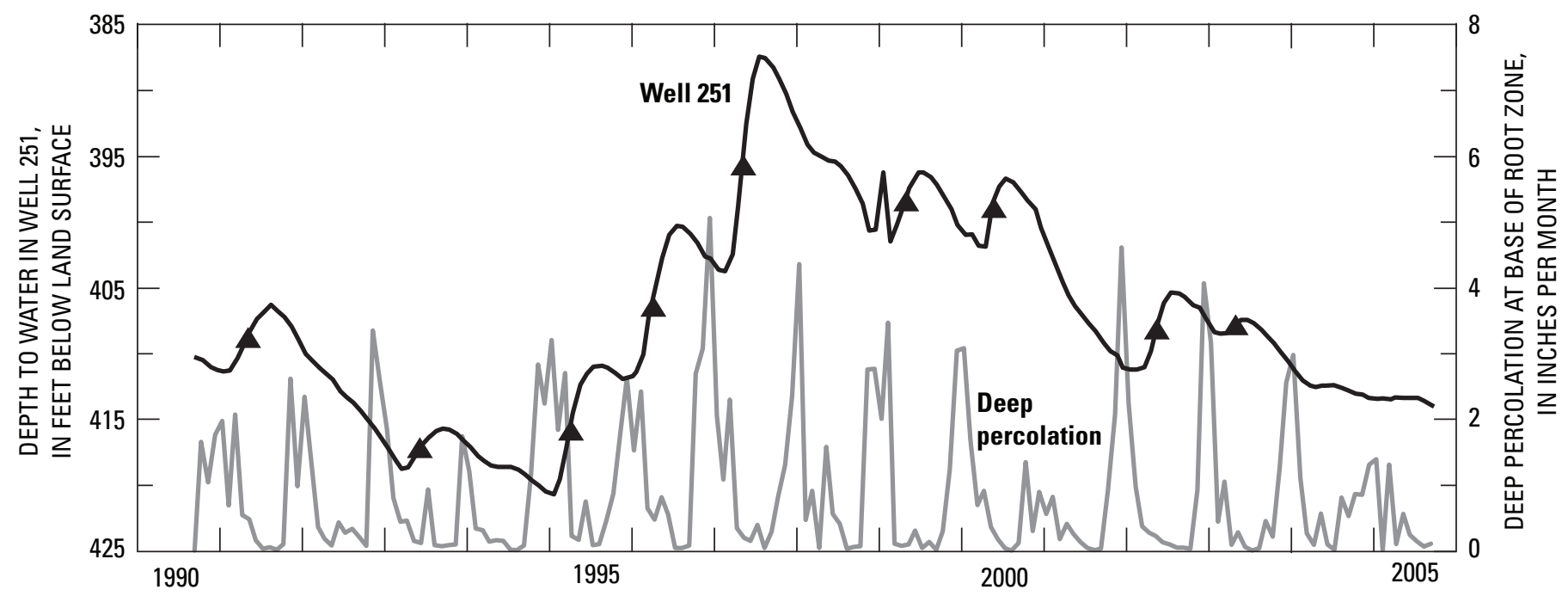

Figure 8. Depth to water in well 251 and monthly rate of deep percolation at the base of the root zone at the well site, Spokane Valley-Rathdrum Prairie aquifer, Washington and Idaho.

Table 2. Estimated transmission time for precipitation infiltration to travel from base of root zone to water table, Spokane ValleyRathdrum Prairie aquifer, Washington and Idaho.

\begin{tabular}{cc}
\hline $\begin{array}{c}\text { Depth from land surface } \\
\text { to water table } \\
\text { (feet) }\end{array}$ & $\begin{array}{c}\text { Transmission time } \\
\text { (months) }\end{array}$ \\
\hline $0-40$ & 0 \\
$40-120$ & 1 \\
$120-200$ & 2 \\
$200-280$ & 3 \\
$280-360$ & 4 \\
$360-440$ & 5 \\
\hline
\end{tabular}

The monthly volumetric rate of recharge (in cubic feet per second) from precipitation to the (1) Idaho side of the SVRP aquifer model, (2) Washington side of the model, and (3) entire model is shown in figure 9. The volumetric rate of recharge from precipitation is lower on the Washington side than on the Idaho side. Also, the recharge peaks earlier on the Washington side than on the Idaho side, because the water table generally is at a shallower depth on the Washington side than on the Idaho side.

The average volumetric rate of recharge and the average recharge flux from October 1990 through September 2005 is shown in table 3 . For the entire model, the average volumetric rate of recharge from precipitation is $228 \mathrm{ft}^{3} / \mathrm{s}$. The average volumetric rate of recharge on the Idaho side of the model is about twice that on the Washington side. The average recharge flux is calculated as the average volumetric rate divided by the surface area. Although precipitation generally is higher on the Idaho side of the model than on the Washington side, the recharge flux is about the same on both sides. This is because a higher percentage of precipitation enters the subsurface through recharge wells and infiltration basins on the Washington side than on the Idaho side. Infiltration through recharge wells and infiltration basins generally is subject to less evapotranspiration loss than infiltration through permeable surfaces.

Table 3. Average volumetric rate of recharge and average recharge flux from precipitation, Spokane Valley-Rathdrum Prairie aquifer, Washington and Idaho, October 1990 through September 2005.

[Volumetric rate of recharge: PS, recharge from precipitation on permeable surface; IS, Recharge from precipitation runoff from impermeable surface to recharge well, infiltration basin, or adjacent permeable surface; Abbreviations: $\mathrm{ft}^{3} / \mathrm{s}$, cubic foot per second; $\mathrm{mi}^{2}$, square mile; in/yr, inch per year; $\mathrm{ft} / \mathrm{d}$, foot per day]

\begin{tabular}{|c|c|c|c|c|c|c|}
\hline \multirow{2}{*}{ Region } & \multicolumn{3}{|c|}{$\begin{array}{l}\text { Volumetric rate of recharge } \\
\qquad\left(\mathrm{ft}^{3} / \mathrm{s}\right)\end{array}$} & \multirow{2}{*}{$\begin{array}{c}\text { Surface } \\
\text { area } \\
\left(\mathrm{mi}^{2}\right)\end{array}$} & \multicolumn{2}{|c|}{ Recharge flux } \\
\hline & PS & IS & Total & & (in/yr) & $(\mathrm{ft} / \mathrm{d})$ \\
\hline Idaho side & 133 & 22 & 155 & 211 & 10.0 & 0.0023 \\
\hline Washington side & 43 & 30 & 73 & 115 & 8.6 & .0020 \\
\hline Entire model & 176 & 52 & 228 & 326 & 9.5 & .0022 \\
\hline
\end{tabular}




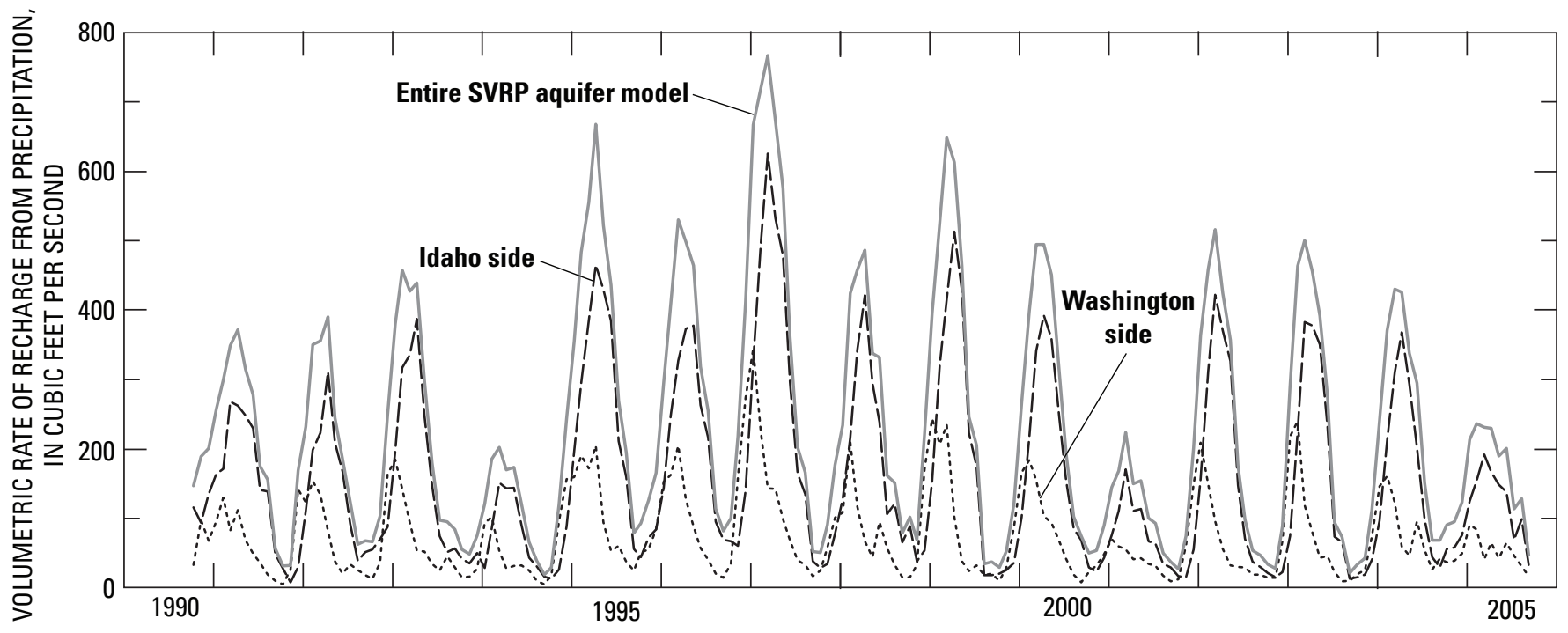

Figure 9. Volumetric rate of recharge from precipitation, Spokane Valley-Rathdrum Prairie aquifer, Washington and Idaho.

\section{Tributary Basins and Adjacent Uplands}

The SVRP aquifer receives flow from higher altitude regions immediately adjacent to the aquifer. These regions are referred to as tributary basins and adjacent uplands or simply as tributary basins. A tributary basin might drain directly into the aquifer or drain into a lake that, in turn, recharges the aquifer. Tributary basins that drain directly to the aquifer are shown in figure 10. Recharge from these basins to the aquifer is estimated in this section of the report. Tributary basins that drain into seven of the nine lakes that border the aquifer are shown in figure 10-Lake Pend Oreille and Coeur d'Alene Lake are not included. Recharge from the lakes to the aquifer is estimated in section, "Lakebed Seepage and Surface Overflows."

Flow from tributary basins to the SVRP aquifer is estimated using regional regression equations developed by Hortness and Berenbrock (2001). These regression equations are developed for Idaho and parts of adjacent States to estimate the mean annual discharge at ungaged sites on streams that are unaffected by regulations and (or) diversions. The methodology uses the USGS StreamStats web application (Ries and others, 2004) and the ArcGIS-ArcHydro application developed by Environmental Systems Research Institute, Inc. Both tools make use of the same techniques and underlying data sets. In the following discussion, this methodology is referred to as StreamStats. The estimation of tributary basin discharge to the aquifer was performed by Jon Hortness and is included in the report by Kahle and Bartolino (2007).
The regression equations in StreamStats are developed by relating the mean annual discharge values for long-term gaging stations to various physical and climatic characteristics (basin characteristics) of the upstream drainage basin. For a gaged site, the mean annual discharge is the average of all annual discharges in the data record or during a specific period of years. For an ungaged site, the estimated mean annual discharge is a long-term average for a time period that is comparable to the length of record used to develop the regression equations. Typically, the data record spans tens of years.

To apply StreamStats, 72 tributary basin outlet points are selected along the model boundary (fig. 10). For each outlet point, the upstream drainage basin is delineated. The combination of all delineated basins encompasses most of the surrounding uplands that drain into the SVRP aquifer. Small gaps between adjacent basins are not included. For each delineated basin, StreamStats is used to estimate the mean annual discharge at the outlet point. Because bedrock occurs either at the basin surface or under a thin layer of soil, the assumption is that minimal subsurface discharge occurs at the outlet. Therefore, stream discharge accounts for nearly all discharge from the basin. However, as the stream crosses from the tributary basin onto the aquifer, all stream water quickly soaks into the ground because of the highly permeable nature of the aquifer material.

The 72 tributary basins range in area from 0.3 to $24 \mathrm{mi}^{2}$. The estimated mean annual discharge ranges from 0.0037 to $15 \mathrm{ft}^{3} / \mathrm{s}$, and the sum of the mean annual discharges of all 72 


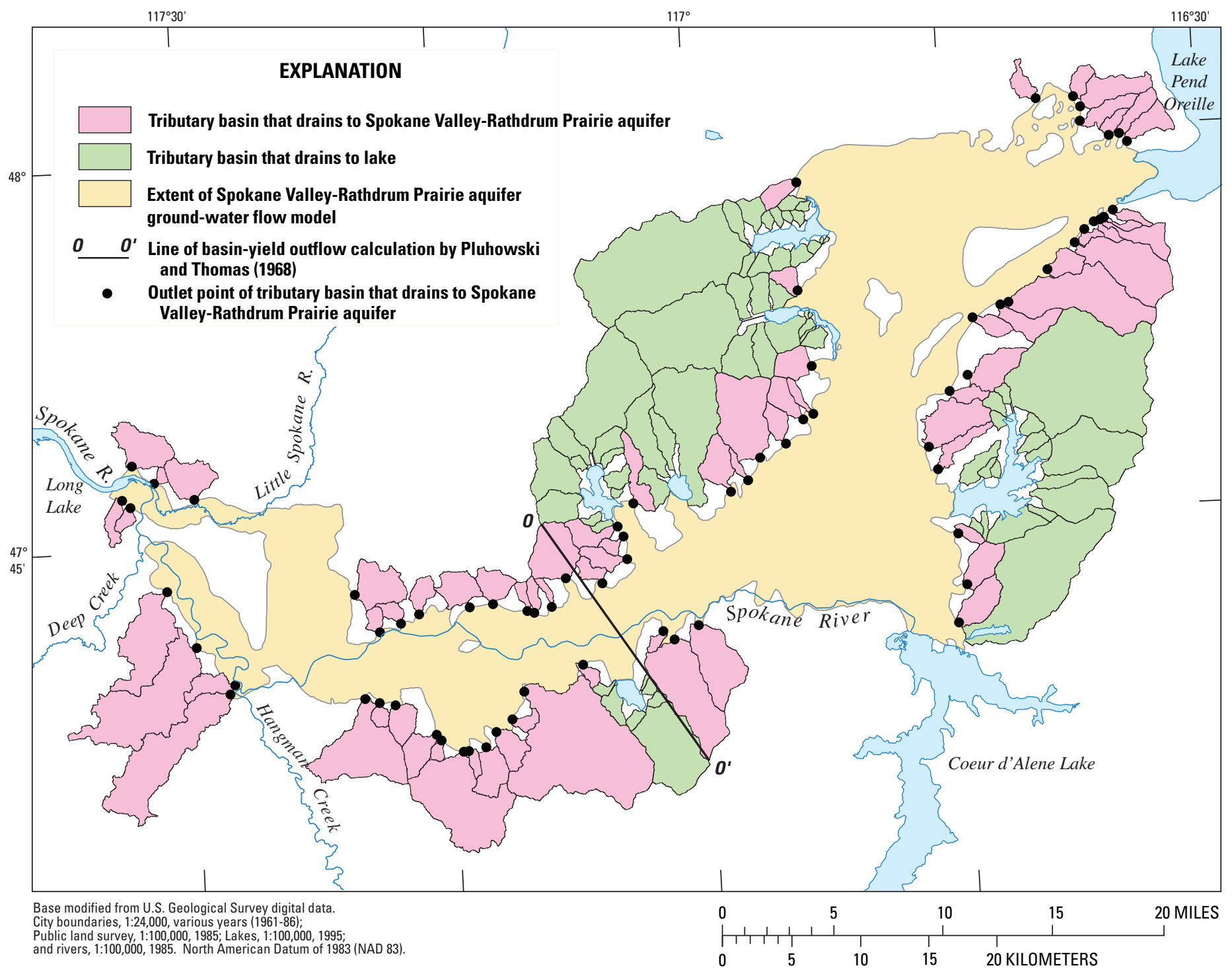

Figure 10. Tributary basins that drain to the Spokane Valley-Rathdrum Prairie aquifer and to seven lakes that border the aquifer, Washington and Idaho.

tributary basins is $112 \mathrm{ft}^{3} / \mathrm{s}$. StreamStats also provides error statistics on the estimated discharge values. Typically, the 67-percent confidence interval ranges from 0.4 to 1.6 times the estimated value. An assessment of the StreamStats estimates is included in the section, "Lakebed Seepage and Surface Overflow."

The mean annual discharge estimated by StreamStats is the long-term average flow from a tributary basin to the SVRP aquifer. For a particular month, the flow from the tributary basin is higher or lower than the long-term average value. To allow for temporal (monthly) variability in flow, a scaling index is used to convert the long-term average flow into the flow for a particular month. In this study, monthly flow on the Little Spokane River at the gaging station at Dartford, Washington, is assumed to be an appropriate scaling index. Because the tributary basins that drain to the Little Spokane River are in close proximity to the tributary basins that drain to the aquifer, these two sets of basins likely share similar physical and climatic characteristics. 
The monthly flow from a tributary basin to the SVRP aquifer is estimated as

$$
Q_{m}=Q_{a} \times \frac{L_{m}}{L_{a}},
$$

where

$Q_{m} \quad$ is the flow from the tributary basin for a given month,

$Q_{a} \quad$ is the long-term average flow (mean annual discharge) estimated by StreamStats for the tributary basin,

$L_{m} \quad$ is the corresponding flow on the Little Spokane River at the gaging station at Dartford for the given month, and

$L_{a} \quad$ is the long-term average flow on the Little Spokane River at the gaging station at Dartford.

The scaling index $\left(L_{m} / L_{a}\right)$ for each month from October 1990 to September 2005 is shown in figure 11. The long-term average flow at the gaging station at Dartford is computed using discharge data for 1960-2000.

\section{Lakebed Seepage and Surface Overflow}

The SVRP aquifer is recharged by lakes that border the aquifer. Of the nine lakes along the perimeter of the model area, only the two largest lakes (Lake Pend Oreille and Coeur d'Alene Lake) have perennial outlet streams. For the seven smaller lakes, outflow occurs as subsurface seepage through the lakebed and occasional surface overflow when the lake level rises above the outlet structure. Because of the highly permeable nature of the aquifer material, the surface overflow soaks into the ground within a short distance of the lake. Therefore, the combined outflow from subsurface lakebed seepage and surface overflow is the amount of recharge from the seven smaller lakes to the aquifer.

In principle, the outflow from a lake can be estimated by the following water-balance equation:

$$
O_{L}=I_{L}+P_{L}-E_{L}-S_{L}
$$

where

$\mathrm{O}_{\mathrm{L}}$ is rate of outflow from the lake,

$I_{L}$ is the rate of inflow to the lake from the surrounding tributary basins,

$P_{L}$ is the rate of direct precipitation on the lake surface,

$E_{L}$ is the rate of evaporation from the lake, and

$S_{L}$ is the rate of change in storage in the lake.

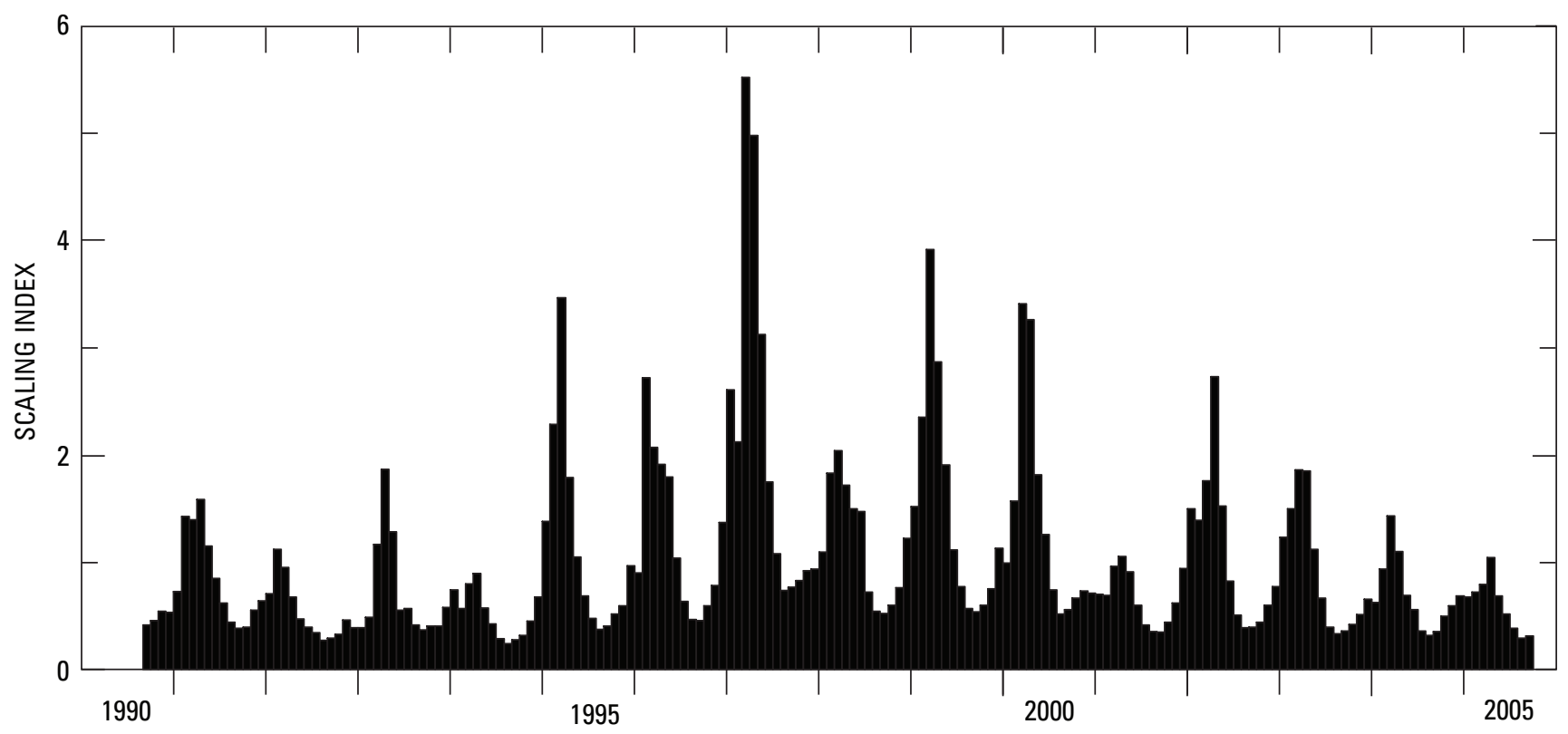

Figure 11. Scaling index used to compute monthly flow from tributary basins to the Spokane Valley-Rathdrum Prairie aquifer, Washington and Idaho. 
Murray (2007) evaluated the terms on the right-hand side of equation 4 for Hayden Lake on a monthly basis from 1998 through 2005. She noted that $P_{L}-E_{L}-S_{L}$ typically is a small percentage of $I_{L}$. Therefore, monthly outflow from the lake can be approximated reasonably by the monthly inflow from surrounding tributary basins. This approximation is assumed to be applicable to the seven smaller lakes along the perimeter of the model area (that is, excluding Lake Pend Oreille and Coeur d'Alene Lake).

Murray (2007) estimated inflows to the seven lakes using the same procedure as that used to estimate flow from tributary basins to the SVRP aquifer. For each lake, outlet points are placed along the lake perimeter. For each outlet point, the upstream tributary basin is delineated (fig. 10) and StreamStats is used to estimate the mean annual discharge. The sum of the mean annual discharges for the surrounding tributary basins is the long-term average inflow to the lake (table 4). Finally, the monthly inflow to the lake is estimated by multiplying the long-term average inflow by the scaling index $\left(\mathrm{L}_{m} / \mathrm{L}_{\mathrm{a}}\right)$ in the same manner as that used to estimate monthly flow from a tributary basin to the aquifer (eq. 3). Assuming monthly inflow to the lake equals monthly outflow from the lake, the longterm average inflow to the lake times the scaling index is the monthly flow from the lake to the aquifer.

An assessment of the StreamStats methodology can be made by comparing the StreamStats estimates with basin water yields calculated by previous investigators. Pluhowski and Thomas (1968) estimated the water yield of the Rathdrum Prairie Basin, defined as all areas upstream of a northnorthwest to south-southeast line drawn at the gaging station on the Spokane River near Otis Orchards (see line 0-0' in fig. 10). For this basin, they estimated a water yield of 530 $\mathrm{ft}^{3} / \mathrm{s}$. When expressed in terms of the flow components used

Table 4. Drainage area and long-term average inflow to seven lakes that border the Spokane Valley-Rathdrum Prairie aquifer, Washington and Idaho.

[Abbreviations: $\mathrm{mi}^{2}$, square mile; $\mathrm{ft}^{3} / \mathrm{s}$, cubic foot per second]

\begin{tabular}{lcc}
\hline \multicolumn{1}{c}{ Lake } & $\begin{array}{c}\text { Drainage area } \\
\left(\mathbf{m i}^{\mathbf{2}} \mathbf{)}\right.\end{array}$ & $\begin{array}{c}\text { Long-term } \\
\text { average inflow } \\
\mathbf{( f t}^{\mathbf{3}} \mathbf{s} \mathbf{)}\end{array}$ \\
\hline Fernan Lake & 18.8 & 12.9 \\
Hauser Lake & 18.3 & 17.4 \\
Hayden Lake & 51.6 & 62.0 \\
Liberty Lake & 11.3 & 4.9 \\
Newman Lake & 24.8 & 20.2 \\
Spirit Lake & 32.8 & 48.4 \\
Twin Lakes & 26.9 & 35.1 \\
\hline
\end{tabular}

in this study, this basin water yield represents the sum of (1) recharge from precipitation to that part of the SVRP aquifer upstream of line $0-0^{\prime}$, , (2) inflows from all tributary basins to that part of the aquifer upstream of line 0-0', and (3) inflows to the aquifer from Fernan, Hauser, Hayden, Newman, Spirit, and Twin Lakes. The second and third items are estimated by StreamStats. For the period of study (1990-2005), the average values of the three items are 165, 86, and $294 \mathrm{ft}^{3} / \mathrm{s}$, respectively, which sum to $545 \mathrm{ft}^{3} / \mathrm{s}$. Although this sum is somewhat higher than Pluhowski and Thomas's (1968) basin water yield of $530 \mathrm{ft}^{3} / \mathrm{s}$, especially because Pluhowski and Thomas's Rathdrum Prairie Basin includes Spirit Valley, which is excluded from the model extent in this study, the comparison does indicate that the StreamStats estimates used in this study are consistent with basin water yields calculated by previous investigators.

For Lake Pend Oreille and Coeur d'Alene Lake, a large part of the lake inflow is discharged to the outlet stream. By comparison, lakebed seepage is a relatively small quantity. Therefore, estimating lakebed seepage by a water-balance calculation for the lake might lead to results that are highly uncertain. Nonetheless, previous investigators have made water-balance calculations for Coeur d'Alene Lake. Seepage from Coeur d'Alene Lake often is estimated in combination with seepage from the segment of the Spokane River upstream of the gaging station near Post Falls. In a study of groundwater inflow to the Rathdrum Prairie, Anderson (1951, p. 20-21) stated that

"Some ground water is believed to be derived from Coeur d'Alene Lake (and the Spokane River between the lake and Post Falls). Approximately three-fourths of the inflow to the lake is gaged and a comparison of estimated total inflow with total surface outflow plus evaporation indicates a seepage loss of about 300 second-feet to ground water."

However, given that the mean annual flow measured at the gaging station near Post Falls for 1913-2001 is about 6,200 $\mathrm{ft}^{3} / \mathrm{s}$ (Kahle and others, 2005, p. 41), the calculated seepage loss of $300 \mathrm{ft}^{3} / \mathrm{s}$ would be within the error in the discharge measurements and is therefore highly uncertain.

Sagstad (1977) applied Darcy's Law to estimate recharge to the SVRP aquifer from Coeur d'Alene Lake and from the segment of the Spokane River upstream of the gaging station near Post Falls. The Darcy's Law calculation was performed for three sections, with flow across section C-C' (Sagstad 1977, fig. 13 and table 7) approximately representing seepage from Coeur d'Alene Lake. Using a hydraulic conductivity of $535 \mathrm{ft} / \mathrm{d}$, a saturated thickness of $150 \mathrm{ft}$, and a watertable gradient of 0.00303 , the flow across section $C-C^{\prime}$ was calculated to be $37 \mathrm{ft}^{3} / \mathrm{s}$. 
For Lake Pend Oreille, Pluhowski and Thomas (1968) estimated lakebed seepage by a water-balance calculation for the east (mostly Idaho) part of the SVRP aquifer. Their seepage estimate for Lake Pend Oreille is $50 \mathrm{ft}^{3} / \mathrm{s}$. However, they noted that because of uncertainties in various flow components, "the actual contribution to the aquifer from Pend Oreille Lake may be as much as 200 cfs."

\section{Losing Segments of Spokane River}

Losing segments of the Spokane River occur where the stream level is higher than the hydraulic head in the aquifer directly under the streambed. Along a losing segment, water seeps from the stream and recharges the aquifer. Consequently, there is less streamflow at the downstream end of a losing segment than at the upstream end of the segment. The amount of flow from the Spokane River to the SVRP aquifer is discussed in the section, "Interaction between Aquifer and Spokane River."

\section{Return Percolation from Irrigation}

Return percolation from irrigation refers to that part of applied irrigation water that is not consumed by evapotranspiration but instead percolates downward past the root zone and eventually reaches the water table. Irrigation includes landscape irrigation (such as lawn watering), agricultural irrigation, and golf course irrigation. For the period of study (1990-2005), nearly all irrigation water applied within the model area is derived from ground-water pumpage. Therefore, return percolation from irrigation actually is water that came from the aquifer.

To estimate water use for landscape irrigation, monthly ground-water withdrawals by water purveyors and by domestic users outside water purveyor service areas is divided into an indoor-use component and an outdoor-use component. For each year, during January, February, March, November, and December, the outdoor-use component is assumed to be zero. Therefore, ground-water withdrawal during those 5 months is entirely for indoor use. For April through October, the indooruse component is assumed to be the average withdrawal during the aforementioned 5 months with no outdoor use. The outdoor-use component is any withdrawal in excess of the indoor-use component. The entire outdoor-use component is assumed to be for landscape irrigation. Based on studies by Oad and others (1997) and Dukes and others (2005), landscape irrigation efficiency is estimated to be 60 percent. Therefore, 40 percent of the outdoor-use component percolates back to the aquifer.
In a water purveyor service area, ground water is pumped from supply wells and distributed to users in the service area. Water purveyor service areas are delineated for four periods: 1990-95, 1996-99, 2000-02, and 2003-05. Within each period, service areas are assumed to remain unchanged. Water purveyor service areas during 2000-02 are shown in figure 12 . For each service area, return percolation is computed from pumpage records for supply wells in the entire service area (see section, "Withdrawals from Wells") and then distributed uniformly over the service area. For the City of Spokane, however, the service area southwest of the city (fig. 12) is excluded from the return percolation calculation as that area is relatively undeveloped and landscape irrigation is expected to be minimal. Outside water purveyor service areas, groundwater withdrawals are estimated on a cell-by-cell basis on a raster grid (see section, "Withdrawals from Wells"). Return percolation is applied to the same cell from which ground water is withdrawn.

For agricultural irrigation outside water purveyor service areas and for self-supplied golf courses, groundwater withdrawals are estimated from crop acreage, irrigation demand, and an assumed irrigation efficiency of 60 percent. Therefore, 40 percent of the pumped water is assumed to percolate back to the aquifer.

The monthly rate of return percolation from all types of irrigation for the entire model area is shown in figure 13. From October 1990 through September 2005, the average rate of return percolation from irrigation is $54 \mathrm{ft}^{3} / \mathrm{s}$ for the entire model area.

\section{Effluent from Septic Systems}

For a water user who discharges to a septic system, 95 percent of the indoor use is assumed to become effluent from septic systems that percolates back to the aquifer. For a water user who discharges to a sewer system, the assumption is that none of the indoor use returns to the aquifer. To determine the areal distribution of effluent from septic systems, a raster of sewer hookup density is constructed for each year from 1990 to 2005 using spatial data of city limits, sewer district boundaries, and density of sewer hook-ups within each sewer district. The sewer hookup density raster for 2000 is shown in figure 14. For each cell in the raster, the sewer hookup density is the fraction of homes in the cell that are connected to a public sewer system. If the sewer hookup density is zero, the cell is not in a sewer district and all homes in the cell discharge to septic systems. In this case, 95 percent of the indoor water use within the cell is returned to the aquifer. If the sewer hookup density is 1 , then the cell is within a sewer district 


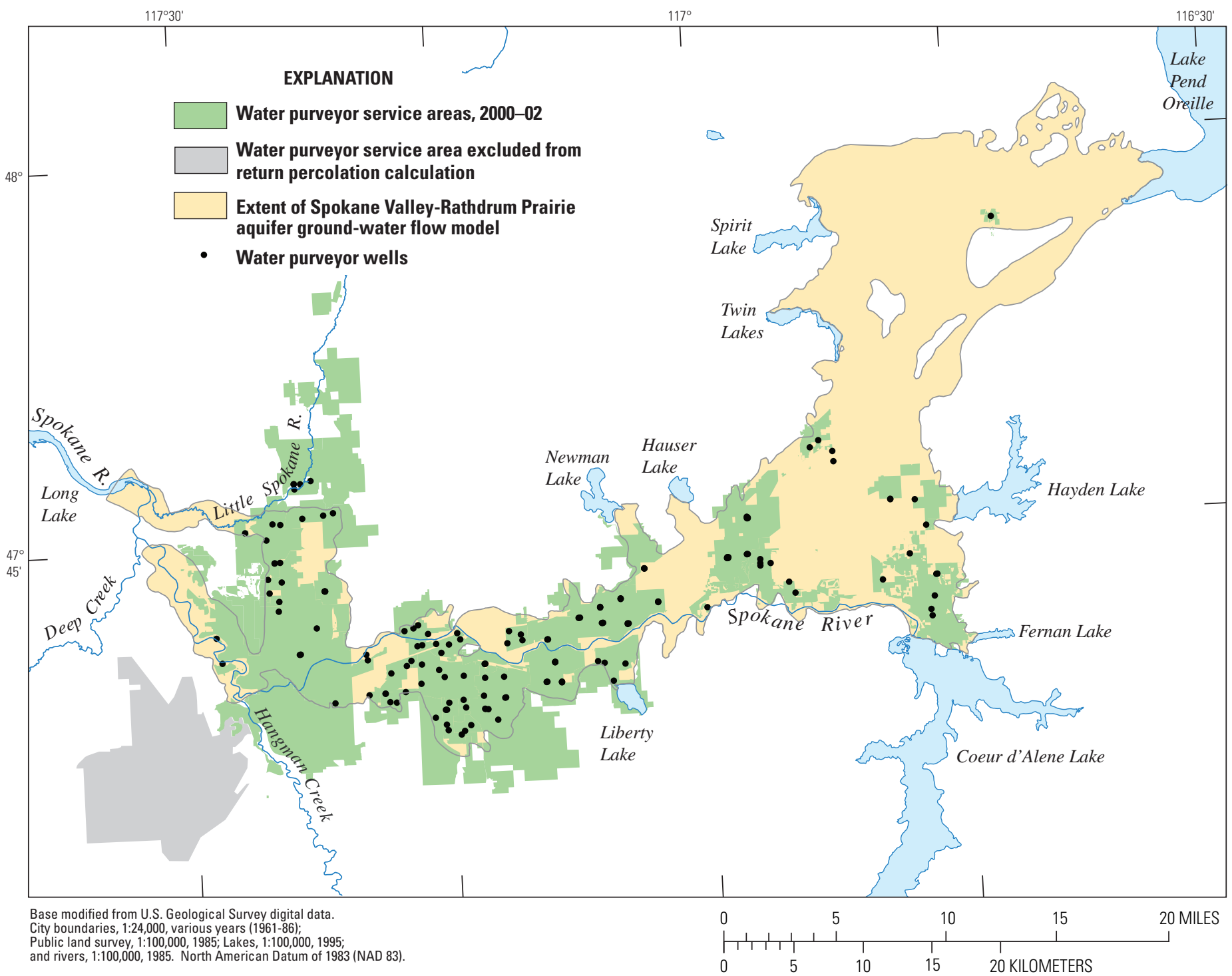

Figure 12. Water purveyor service areas and areal distribution of water purveyor wells, Spokane Valley-Rathdrum Prairie aquifer, 2000-02.

and all homes in the cell discharge to a sewer system. In this case, none of the indoor water use within the cell is returned to the aquifer. If the sewer hookup density is greater than zero but less than 1 , then either the cell is partially within a sewer district or the cell is entirely within a sewer district but not all homes in the cell discharge to the sewer system. In this case, effluent from the septic system is $0.95\left(1-d_{s}\right)$ times the indoor water use in the cell, where $d_{s}$ is the sewer hookup density.
The monthly rate of effluent from septic systems for the entire model area is shown in figure 13. The gradually declining rate is caused by expansion of sewer districts. From October 1990 through September 2005, the average rate of effluent from septic systems is $23 \mathrm{ft}^{3} / \mathrm{s}$ for the entire model area. 


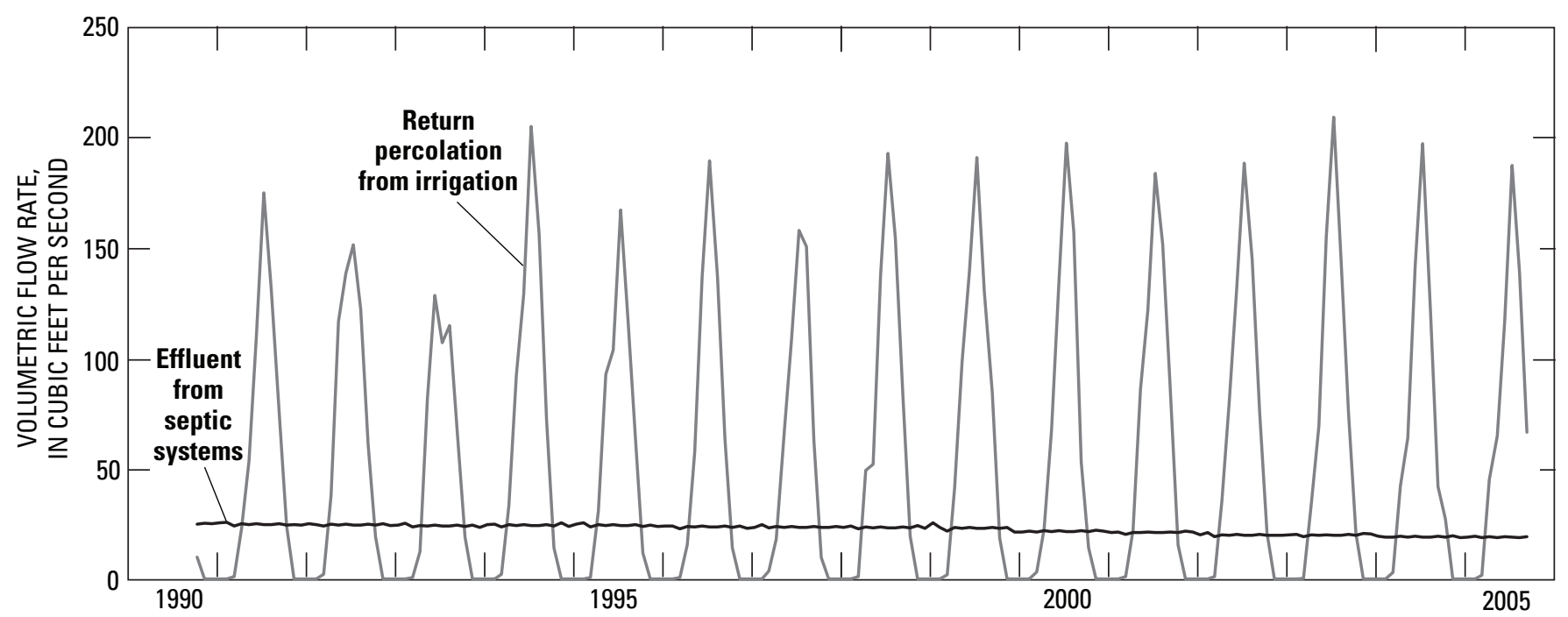

Figure 13. Volumetric rate of return percolation from irrigation and effluent from septic systems, Spokane ValleyRathdrum Prairie aquifer, Washington and Idaho.

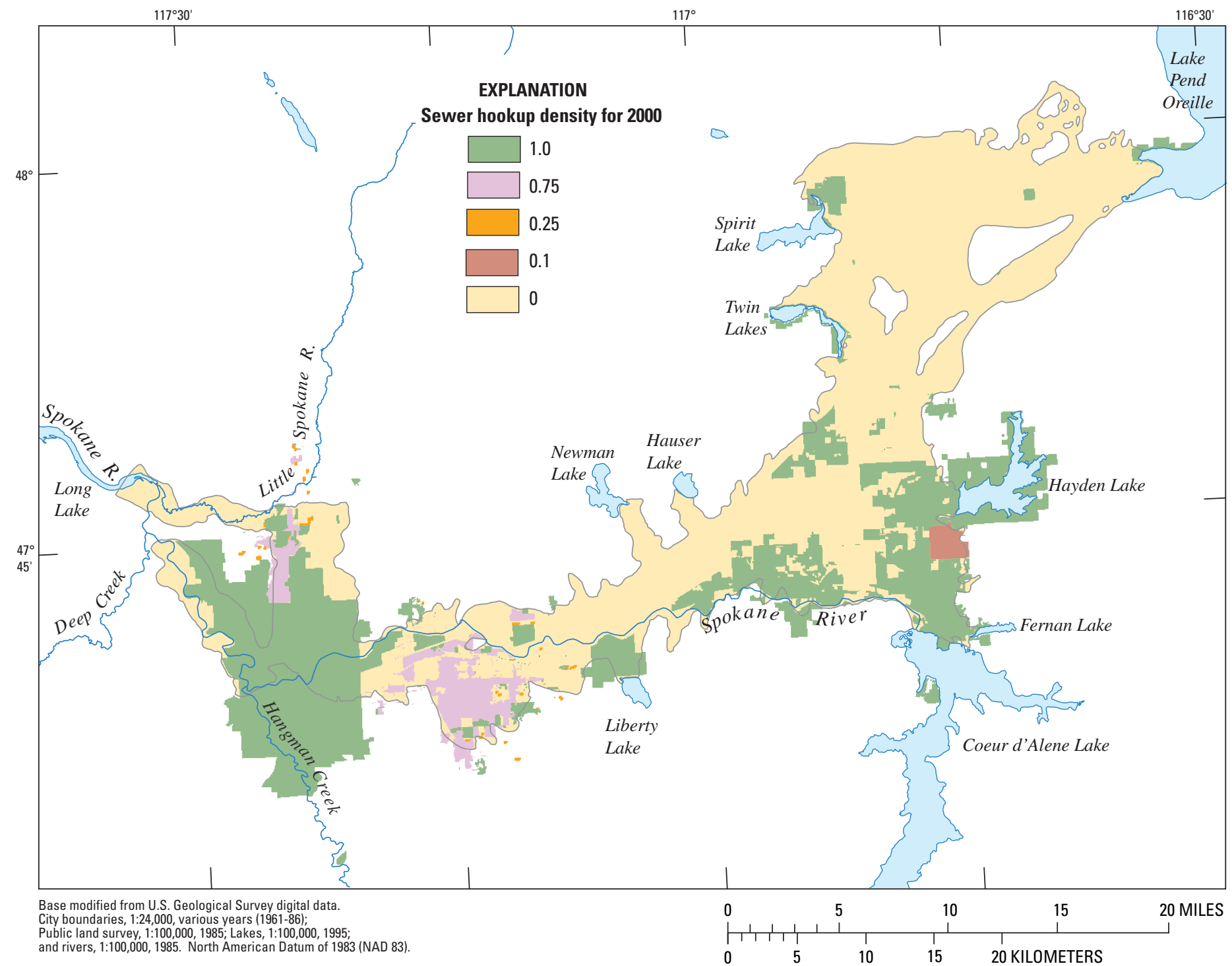

Figure 14. Sewer hookup density for 2000, Spokane Valley-Rathdrum Prairie aquifer, Washington and Idaho. 


\section{Outflows from Aquifer}

Outflows from the SVRP aquifer include (1) groundwater withdrawals from wells, (2) ground-water discharge from the aquifer to gaining segments of the Spokane River, (3) ground-water discharge from the aquifer to the Little Spokane River, and (4) subsurface outflow at the western limit of the model area near Long Lake. For the ground-water flow model in this report, monthly outflows were estimated for October 1990 through September 2005. Areally distributed outflow components were computed on a raster grid with a cell size of 1,320 by $1,320 \mathrm{ft}$ that was aligned with the finite-difference grid used in the model.

\section{Withdrawals from Wells}

Withdrawals of ground water from the SVRP aquifer were estimated for four categories: (1) withdrawals by water purveyors, (2) withdrawals by domestic users outside water purveyor service areas, (3) withdrawals for agricultural irrigation outside water purveyor service areas and by self- supplied golf courses, and (4) withdrawals by self-supplied industries. The combined monthly withdrawal rate for all four categories is shown in figure 15. From October 1990 through September 2005, the average combined withdrawal rate is $317 \mathrm{ft}^{3} / \mathrm{s}$. Individual withdrawal rates for each category are discussed in the following paragraphs.

Data on withdrawals by water purveyors were obtained from 21 water purveyors in the model area for 1990-2005. This work was performed in conjunction with ongoing USGS water-use data collection (Molly Maupin, U.S. Geological Survey, written commun., 2006). The areal distribution of 159 water purveyor wells is shown in figure 12. Monthly withdrawals were obtained for 125 of the 159 wells, and annual withdrawals were obtained for the other 34 wells. For wells with annual withdrawal data, monthly withdrawals are estimated by distributing the annual withdrawal to each month on the basis of the monthly pumping pattern of other wells operated by the same water purveyor or by another water purveyor serving a similar community. The estimated monthly withdrawal rate by all water purveyors is shown in figure 15 . From October 1990 through September 2005, the average withdrawal rate for this category is $205 \mathrm{ft}^{3} / \mathrm{s}$.

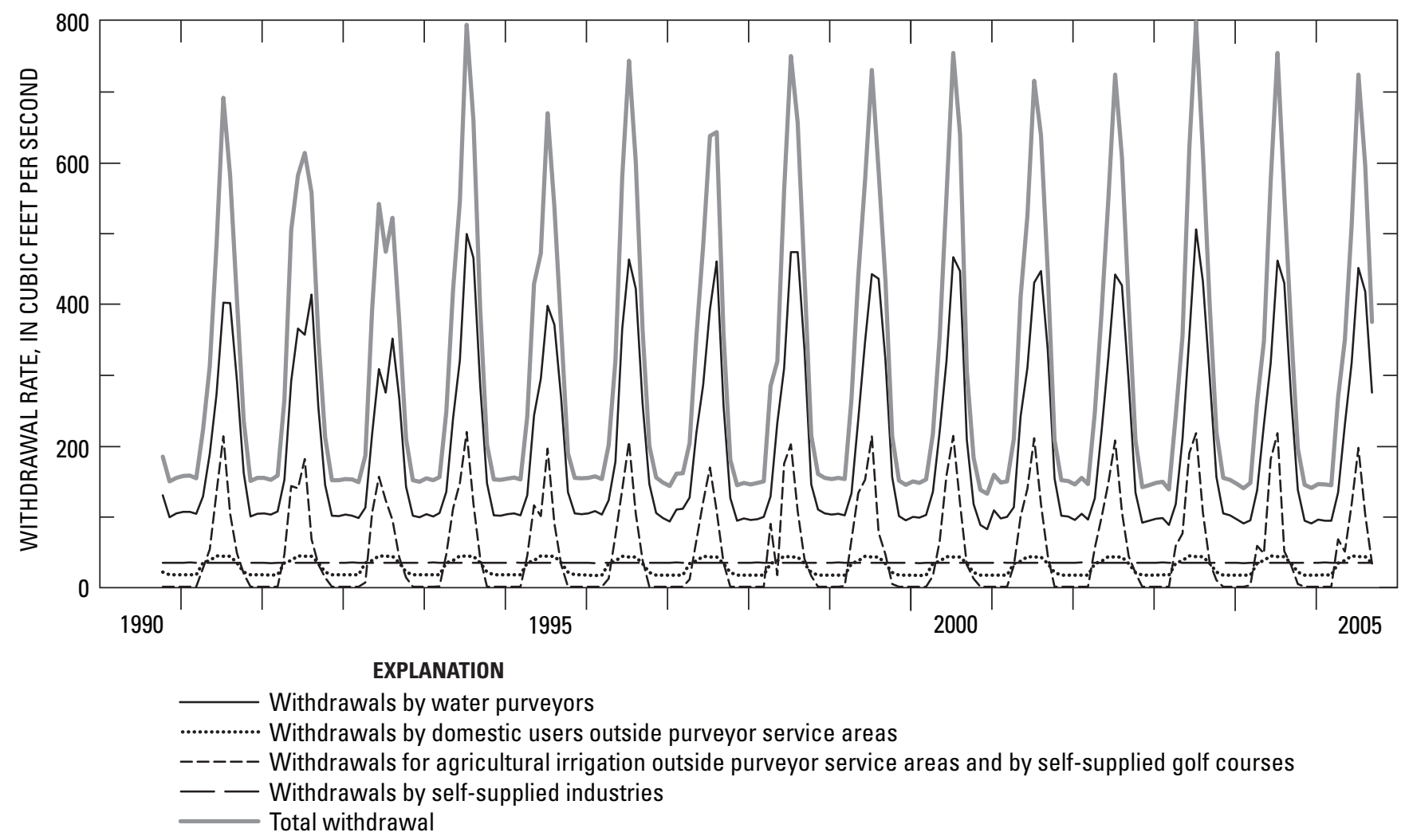

Figure 15. Withdrawal rates from wells, Spokane Valley-Rathdrum Prairie aquifer, Washington and Idaho. 
Data on withdrawals by domestic users outside water purveyor service areas were not available. Monthly withdrawals were assumed to be similar to the average monthly withdrawals for a water purveyor-supplied home in Spokane. The estimated monthly withdrawal rate for a home outside water purveyor service areas is shown in figure 16. A study by the City of Spokane estimated the rate of indoor use for a home is $25.4 \mathrm{ft}^{3} / \mathrm{d}$ (L. Brewer, oral commun., 2006). This indoor use rate is assumed to apply year round for a home outside water purveyor service areas. From April through October, an outdoor-use rate (for landscape irrigation) is added to the indoor-use rate. The outdoor-use rate is based on the outdoor-use pattern for Spokane.

To estimate the areal distribution of withdrawals by domestic users outside water purveyor service areas, the density of homes outside those areas was estimated on a raster grid. The number of homes in each cell was estimated from land-cover data and aerial photographs. The monthly withdrawal rate in each cell was computed as the number of homes in the cell times the monthly withdrawal rate of a home (fig. 16). The estimated monthly withdrawal rate for all homes outside water purveyor service areas is shown in figure 15. From October 1990 through September 2005, the average withdrawal rate for this category is $28 \mathrm{ft}^{3} / \mathrm{s}$.

Withdrawals for agricultural irrigation outside water purveyor service areas and by self-supplied golf courses were estimated from irrigation acreages and irrigation demand. Nearly all withdrawals in this category were on the Idaho side of the SVRP aquifer. Irrigation acreages were estimated from Idaho water rights data and by inspection of aerial photographs. Irrigation acreages are shown on a raster grid of irrigation density in figure 17. For each cell in the raster,

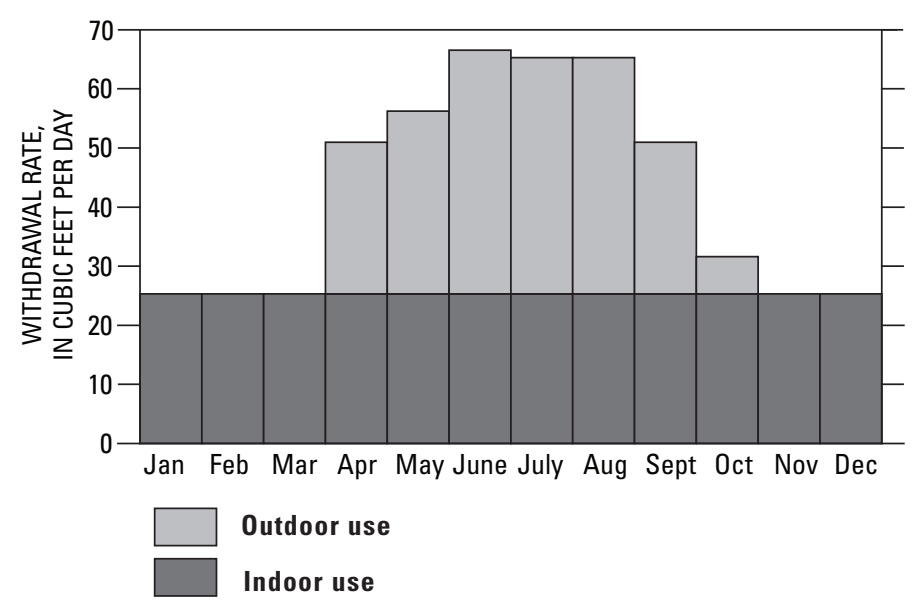

Figure 16. Estimated monthly withdrawal rate for a home outside water purveyor service areas, Spokane Valley-Rathdrum Prairie aquifer, Washington and Idaho. the irrigation density is the percentage of the cell's area that is irrigated. If the irrigation density is 1 , all of the cell's area is irrigated. Conversely, if the irrigation is zero, no irrigation occurs in the cell.

To estimate irrigation demand, a single crop mix is calculated from data published by the National Agricultural Statistics Service (2003, 2004, 2005) and information obtained from the Jacklin Seed Company (G. Jacklin, oral commun., 2006) on grass-seed acreage. Average evapotranspiration rates for each crop are obtained from Allen and Brockway (1983) for Coeur d'Alene. The evapotranspiration rate for grass seed is based on the evapotranspiration rate for pasture but is adjusted to reflect a shorter irrigation season. For golf courses, the evapotranspiration rate for alfalfa is used. Monthly precipitation was obtained from PRISM-derived data downloaded from Oregon State University (http://www.ocs. orst.edu/prism/products/). Assuming that 75 percent of the monthly precipitation was effective in meeting crop needs, the monthly irrigation demand for a cell is calculated as:

$$
R=A \times d_{r} \times \max \left(E_{T}-0.75 P, 0\right)
$$

where

$\mathrm{R}$ is the monthly irrigation demand,

$A$ is the area of the cell,

$d_{r}$ is the irrigation density of the cell,

$E_{T}$ is the monthly evapotranspiration, and

$P$ is the monthly precipitation.

Assuming an irrigation efficiency of 60 percent, the monthly withdrawal for irrigation at a cell is calculated as $\mathrm{R}$ divided by 0.6. Therefore, 40 percent of the irrigation water percolates back to the SVRP aquifer. The estimated monthly withdrawal rate for agricultural irrigation outside water purveyor service areas and for self-supplied golf courses is shown in figure 15. From October 1990 through September 2005, the average withdrawal rate for this category is $51 \mathrm{ft}^{3} / \mathrm{s}$.

For withdrawals by self-supplied industries, only users that withdraw more than 500 acre-ft/yr $\left(0.7 \mathrm{ft}^{3} / \mathrm{s}\right)$ were explicitly included in the model. On the Washington side of the SVRP aquifer, seven wells that meet this criterion were identified from a review of withdrawal data reported by $\mathrm{CH} 2 \mathrm{M}$ Hill (1998) and Golder Associates, Inc. (2004). On the Idaho side, two wells were identified. Withdrawals for both wells were estimated from the Idaho water rights database (http:// www.idwr.idaho.gov/gisdata/new\%20data\%20download/ water_rights.htm). Typically, the actual withdrawal is somewhat less than the full water right. Therefore the actual withdrawal was assumed to be five-sevenths of the full water right. The estimated annual withdrawals from these nine wells and the withdrawal rates, assuming constant year-round pumping, are given in table 5. The total estimated withdrawal rate is about $34 \mathrm{ft}^{3} / \mathrm{s}$. This rate is assumed to remain constant from October 1990 to September 2005 (fig. 15). 


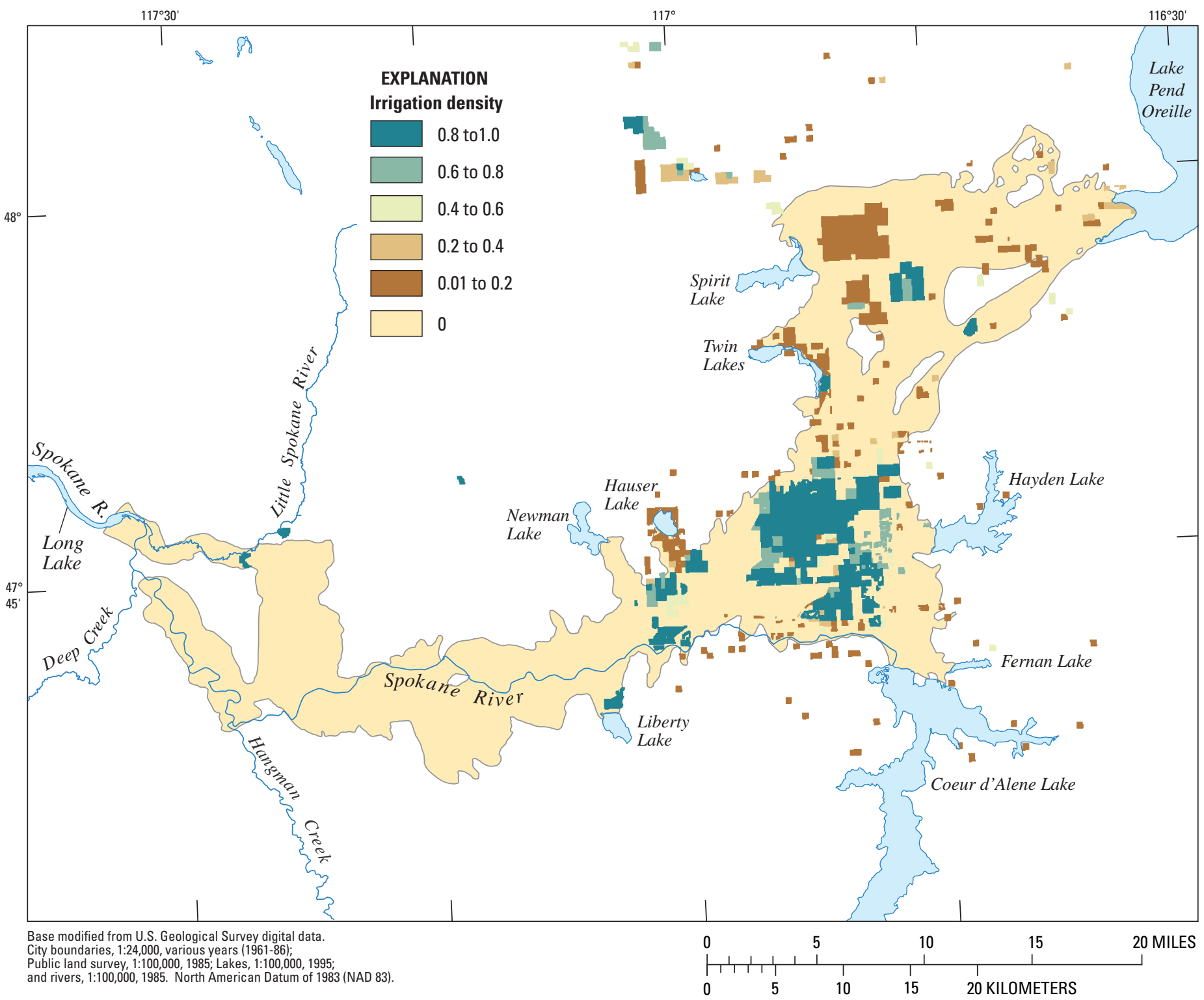

Figure 17. Irrigation density for acreages outside water purveyor service areas and for self-supplied golf courses, Spokane ValleyRathdrum Prairie aquifer, Washington and Idaho.

Table 5. Estimated annual withdrawals by self-supplied industries and withdrawal rates, Spokane ValleyRathdrum Prairie aquifer, Washington and Idaho.

[Abbreviations: acre-ft, acre-foot; $\mathrm{ft}^{3} / \mathrm{s}$, cubic foot per second]

\begin{tabular}{llrr}
\hline \multicolumn{1}{c}{ Well identification } & State & $\begin{array}{c}\text { Annual withdrawal } \\
\text { (acre-ft) }\end{array}$ & $\begin{array}{c}\text { Withdrawal rate } \\
\left(\mathbf{f t t}^{\mathbf{3}} \mathbf{s}\right)\end{array}$ \\
\hline Diamond National Corporation & Idaho & 517 & 0.71 \\
Riley Creek Lumber Company & Idaho & 627 & .87 \\
Kaiser Mead N Plant & Washington & 2,812 & 3.88 \\
Kaiser Mead S Plant & Washington & 565 & .78 \\
Kaiser Trentwood Section 2 & Washington & 4,098 & 5.66 \\
Kaiser Trentwood Section 10 & Washington & 10,538 & 14.55 \\
Kaiser Trentwood Section 11 & Washington & 398 & .55 \\
Honeywell-Johnson Matthey Electric & Washington & 517 & .71
\end{tabular}




\section{Gaining Segments of Spokane River}

Gaining segments of the Spokane River occur where the stream level is lower than the hydraulic head in the aquifer directly under the streambed. Along a gaining segment, ground water discharges from the aquifer and flows to the stream. Consequently, there is more streamflow at the downstream end of a gaining segment than at the upstream end of the segment. The amount of discharge from the SVRP aquifer to the Spokane River is discussed in the section, "Interaction Between Aquifer and Spokane River."

\section{Little Spokane River}

The SVRP aquifer discharges to the Little Spokane River along the valley north of Five Mile Prairie. This part of the aquifer is known as the Little Spokane River Arm. Ground-water discharge to the river can be estimated from the streamflow gain between two gaging stations on the Little Spokane River (fig. 18). In the following discussion, $Q_{A D}$ refers to streamflow at the gaging station at Dartford, which is about 1 mi upstream of where the Little Spokane River enters the aquifer, and $Q_{N D}$ refers to streamflow at the gaging station near Dartford, which is about 3 mi upstream of where the Little Spokane River flows into the Spokane River (fig. 18).

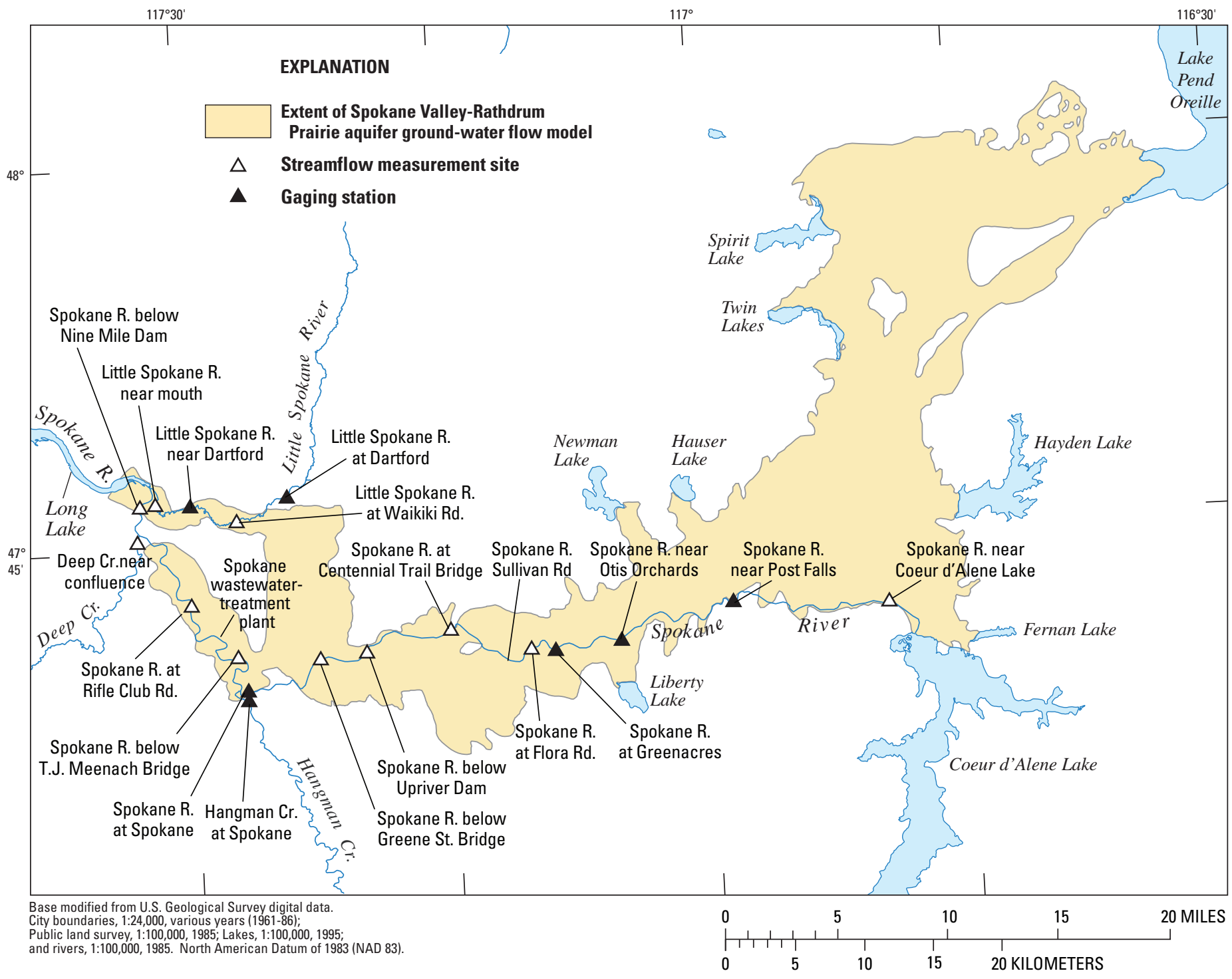

Figure 18. Locations of gaging stations and streamflow measurement sites on the Spokane and Little Spokane Rivers, Spokane ValleyRathdrum Prairie aquifer, Washington and Idaho. 
The streamflow gain between the two gaging stations is $Q_{N D}$ $-Q_{A D}$. The assumption is that this gain represents groundwater discharge from the aquifer.

Daily values of $Q_{N D}-Q_{A D}$ and $Q_{A D}$ are shown in figure 19. The data record is from October 1997 through September 2005. The average streamflow gain for the entire data set is $248 \mathrm{ft}^{3} / \mathrm{s}$. There does not appear to be a strong trend of increasing or decreasing streamflow gain with $Q_{A D}$. However, when $Q_{A D}$ is greater than $500 \mathrm{ft}^{3} / \mathrm{s}$, the scatter in the plotted points becomes much larger. The scatter likely is caused by inherent streamflow measurement error, estimated as 5 percent of the measured streamflow value (Sauer and Meyer, 1992). At higher streamflows, the computed streamflow gain can fall within the streamflow measurement error and, thus, become highly uncertain.

Streamflow measurements at a site near the mouth of the Little Spokane River during September 2004 and August 2005 , indicate a streamflow loss of 16 to $31 \mathrm{ft}^{3} / \mathrm{s}$ from the gaging station near Dartford to the streamflow measurement site near the mouth of the river. These results are unexpected in a ground-water discharge area of the SVRP aquifer and could be caused by inaccuracies in streamflow measurements. Because the streamflow loss is small, the interaction between the aquifer and the Little Spokane River downstream of the gaging station near Dartford might be justifiably characterized as minimal.

\section{Subsurface Outflow}

At the west end of the Little Spokane River Arm, the model terminates at the eastern end of Long Lake (the reservoir on the Spokane River behind Long Lake Dam). In this area, the aquifer is divided into an upper unit and a lower unit by a clay layer. The upper unit is in direct hydraulic contact with Long Lake. Ground-water discharge from the upper unit to Long Lake probably is minimal because most of the outflow likely has entered the Little Spokane River. Hydrologic conditions in the lower unit are not well known. Drillers' reports indicate that the lower unit remains confined under Long Lake for at least 1 or $2 \mathrm{mi}$ beyond the model boundary, but the clay layer eventually pinches out, thus allowing outflow from the lower unit to Long Lake (John Covert, Washington State Department of Ecology, written commun., 2005). This interpretation is supported by an apparent correlation between the water level in well 99, which is completed in the lower unit, and the lake level of Long Lake (fig. 20). Declines in the water level in the well during January and March 2005 coincide with declines in the lake level. However, the rate of outflow from the lower unit is not known.

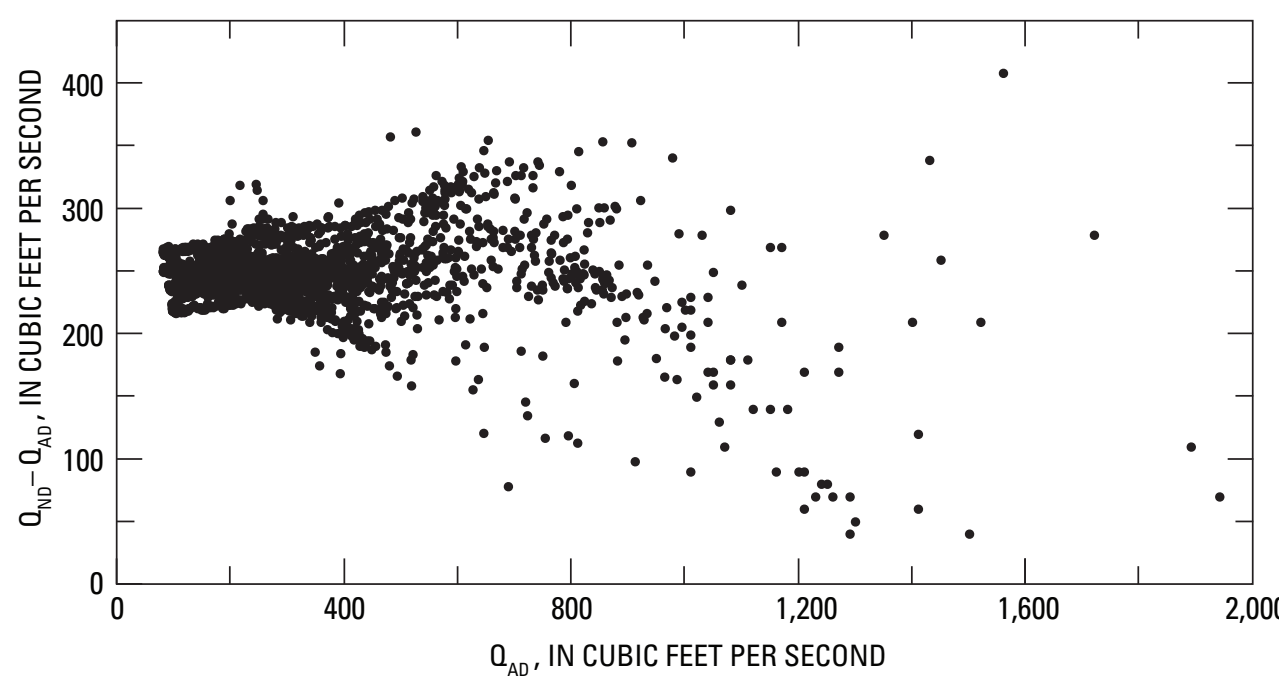

Figure 19. Daily streamflow gain on the Little Spokane River between gaging stations at Dartford $\left(\mathrm{O}_{\mathrm{AD}}\right)$ and near Dartford $\left(\mathrm{O}_{\mathrm{ND}}\right)$ and streamflow at the gaging station at Dartford, Spokane Valley-Rathdrum Prairie aquifer, Washington and Idaho. 


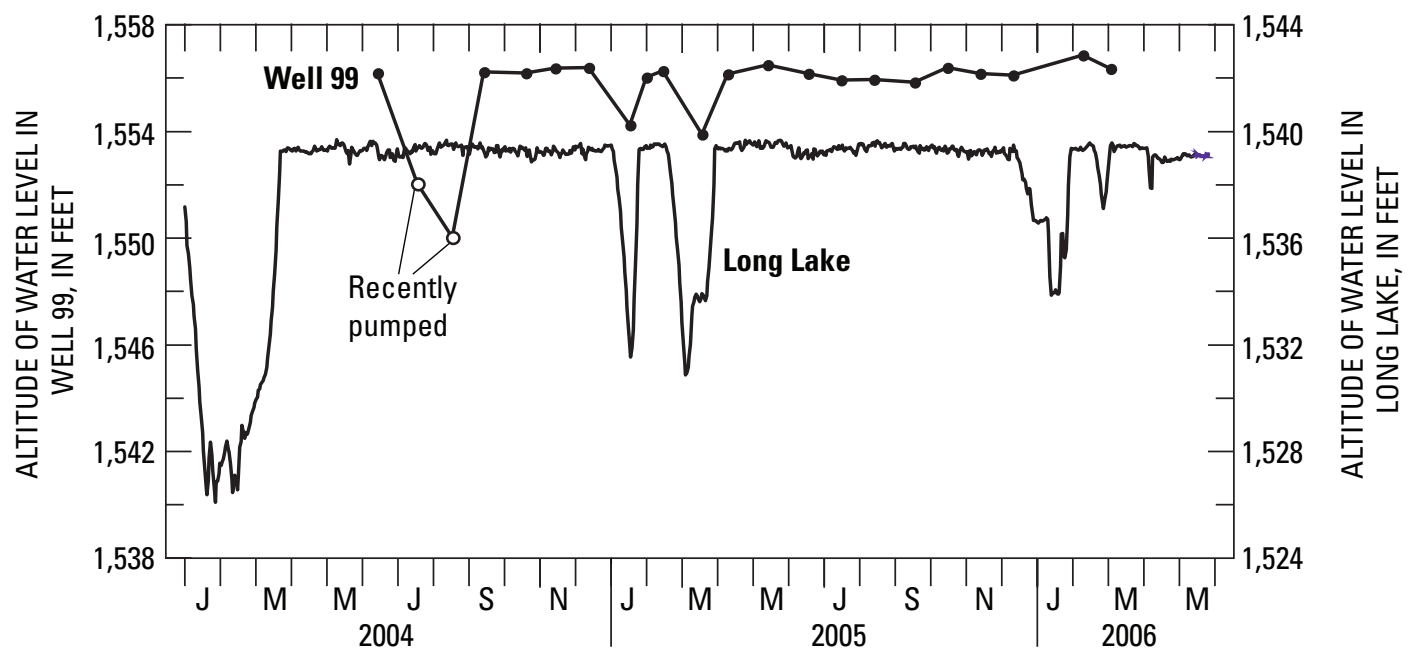

Figure 20. Water levels in well 99 and in Long Lake, Spokane Valley-Rathdrum Prairie aquifer, Washington and Idaho.

\section{Interaction Between Aquifer and Spokane River}

For nearly its entire length within the study area, the Spokane River interacts dynamically with the SVRP aquifer. Kahle and others (2005) summarized previous investigations of this river-aquifer interaction. MacInnis and others (2004, p. 15) characterized segments of the Spokane River as gaining, losing, transitional (varying between gaining and losing depending on the magnitude of the river flow), or minimal. These characterizations were based on nearly simultaneous streamflow measurements (seepage run) made on the Spokane River during September 13-16, 2004 (Kahle and others, 2005, p. 44, table 15), and estimated low-flow values based on historical data and computer modeling. Therefore, these characteristics describe the Spokane River during low-flow conditions, which occur in late summer.

During 2005 and 2006, additional streamflow measurements were made on the Spokane River to refine the understanding of the river-aquifer interaction (table 6, fig. 18). The USGS conducted seepage runs along the Spokane River during August 26-31, 2005, and on August 8, 2006. The seepage run during August 26-31, 2005, encompassed nearly the entire length of the Spokane River in the study area (from just downstream of Coeur d'Alene Lake to below Nine Mile Dam). The seepage run on August 8, 2006, focused on the river segment from the Centennial Trail Bridge to the site below Greene Street Bridge (fig. 18). In addition, Gregory and Covert (2005) measured stream-water temperature along the Spokane River to detect ground-water discharge to the river.
They noted that

"In late summer/early autumn conditions, the Spokane River discharges to the SVRP aquifer upstream from Sullivan Road. Downstream from this point, the river receives aquifer water."

The seepage run during August 26-31, 2005, indicates that the Spokane River lost $606 \mathrm{ft}^{3} / \mathrm{s}$ from the most upstream measurement site near Coeur d'Alene Lake to the measurement site at Flora Road (table 6). From the Flora Road to the Centennial Trail Bridge site, data indicate a net gain of $360 \mathrm{ft}^{3} / \mathrm{s}$. However, Gregory and Covert (2005) noted that the gaining segment actually occurs downstream of the Sullivan Road site (fig. 18). From the Centennial Trail Bridge site to the site below Greene Street Bridge, data indicate a net gain in streamflow of $233 \mathrm{ft}^{3} / \mathrm{s}$. However, the seepage run on August 8, 2006, indicates that this segment of the river actually comprises of a losing segment from the Centennial Trail Bridge site to the site downstream of Upriver Dam and a gaining segment from the site downstream of Upriver Dam to the site downstream of Greene Street Bridge. The river lost $112 \mathrm{ft}^{3} / \mathrm{s}$ from the site downstream of Greene Street Bridge to the gaging station at Spokane. From this gaging station to the site downstream of Nine Mile Dam, after subtracting inflows from Hangman Creek and effluent from the Spokane wastewater-treatment plant, the net gain from ground-water discharge to the river is about $267 \mathrm{ft}^{3} / \mathrm{s}$. Overall, from the most upstream site near Coeur d'Alene Lake to the most downstream site below Nine Mile Dam, the Spokane River gained a net amount of $142 \mathrm{ft}^{3} / \mathrm{s}$ from exchange with the aquifer based on the August 26-31, 2005 seepage run. 
Table 6. Streamflow measurements made on the Spokane River and some tributaries to determine streamflow gains (positive values) and losses (negative values) between measurement sites, Spokane Valley-Rathdrum Prairie aquifer, Washington and Idaho, August 26-31, 2005, and August 8, 2006.

[Location of sites or gaging station shown in figure 18. Abbreviations: $\mathrm{ft}^{3} / \mathrm{s}$, cubic foot per second; --, not computed; -, not measured]

\begin{tabular}{|c|c|c|c|c|}
\hline \multirow[b]{2}{*}{ Measurement site or gaging station } & \multicolumn{2}{|c|}{ August 26-31, 2005} & \multicolumn{2}{|c|}{ August 8, 2006} \\
\hline & $\begin{array}{c}\text { Discharge } \\
\left(\mathrm{ft}^{3} / \mathbf{s}\right)\end{array}$ & $\begin{array}{c}\text { Gain or loss } \\
\qquad\left(\mathrm{ft}^{3} / \mathrm{s}\right)\end{array}$ & $\begin{array}{c}\text { Discharge } \\
\left(\mathrm{ft}^{3} / \mathrm{s}\right)\end{array}$ & $\begin{array}{c}\text { Gain or loss } \\
\qquad\left(\mathrm{ft}^{3} / \mathrm{s}\right)\end{array}$ \\
\hline Spokane River near Coeur d'Alene Lake & 738 & -- & - & -- \\
\hline Spokane River near Post Falls & 447 & -291 & - & -- \\
\hline Spokane River near Otis Orchards & 256 & -191 & - & -- \\
\hline Spokane River at Greenacres & 146 & -110 & - & -- \\
\hline Spokane River at Flora Road & 132 & -14 & - & -- \\
\hline Spokane River at Centennial Trail Bridge & 492 & 360 & 579 & -- \\
\hline Spokane River below Upriver Dam & - & -- & 525 & -54 \\
\hline Spokane River below Greene Street Bridge & 725 & 233 & 869 & 344 \\
\hline Spokane River at Spokane & 613 & -112 & 767 & -102 \\
\hline Hangman Creek at Spokane & 1.5 & -- & - & -- \\
\hline Spokane River below T.J. Meenach Bridge & 703 & 88.5 & - & -- \\
\hline Spokane Wastewater Treatment Plant discharge ${ }^{1}$ & 56 & -- & - & -- \\
\hline Spokane River at Rifle Club Road & 797 & 38 & - & -- \\
\hline Deep Creek near confluence & 0 & -- & - & -- \\
\hline Spokane River below Nine Mile Dam & 938 & 141 & - & -- \\
\hline
\end{tabular}

${ }^{1}$ Spokane Wastewater Treatment Plant discharge value provided by John Convert, Washington State Department of Ecology, written. commun., 2005

For times other than late summer, the characteristics of streamflow gains and losses on the Spokane River are less well known. Daily streamflow data are available since 1999 for four gaging stations on the Spokane River in the model area (fig. 18). Streamflow gains or losses between the various gaging stations and streamflow at the gaging station near Post Falls $\left(Q_{p F}\right)$ are shown in figure 21. Subtracting the streamflow at an upstream gaging stream from the streamflow at a downstream gaging station gives the streamflow gain between the two stations if the result is positive and the streamflow loss if the result is negative. Although figure 21 shows significant scatter among the plotted points, a linear relation is fitted to that part of the data where $Q_{p F}$ is less than or equal to 10,000 $\mathrm{ft}^{3} / \mathrm{s}$. The fitted line provides an overall description of how the streamflow gains or losses vary with $Q_{P F}$. However, when $Q_{p F}$ is greater than $10,000 \mathrm{ft}^{3} / \mathrm{s}$, the scatter is so large that it is difficult to discern a trend.
The fitted lines in figures $21 \mathrm{~A}$ and $21 \mathrm{~B}$ indicate that the river segments from the gaging station at Post Falls to both the gaging stations near Otis Orchards and at Greenacres are net losing segments, and the magnitude of streamflow loss increases with increasing $Q_{P F}$. Conversely, the fitted lines in figures $21 \mathrm{C}$ and $21 \mathrm{D}$ indicate that the river segments from both gaging stations near Otis Orchards and at Greenacres to the gaging station at Spokane are net gaining segments, and the magnitude of the streamflow gain decreases with increasing $Q_{P F}$. Lastly, the fitted line in figure $21 \mathrm{E}$ indicates that the river segment from gaging stations near Post Falls to at Spokane is a net gaining segment when $Q_{P F}$ is less than about 7,000 ft $\mathrm{ft}^{3} / \mathrm{s}$ but is a net losing segment when $Q_{P F}$ is greater than about 7,000 $\mathrm{ft}^{3} / \mathrm{s}$. The river segment between the gaging stations near Otis Orchards and at Greenacres is not considered because the two gaging stations are close to each other and the computed gains or losses generally fall within the streamflow measurement errors except for very low streamflows. 


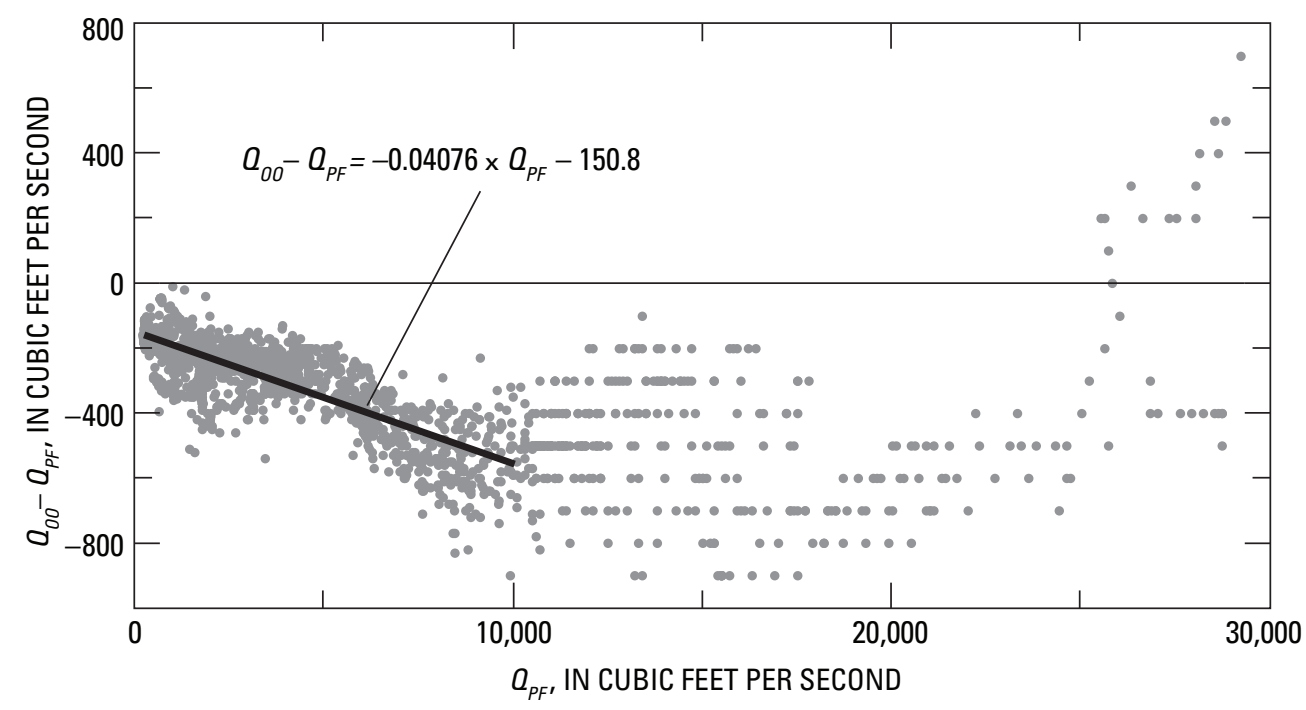

A. Daily streamflow gain (positive value) or loss (negative value) on the Spokane River between gaging stations near Post Falls $\left(Q_{P F}\right)$ and near Otis Orchards $\left(Q_{00}\right)$ and streamflow at gaging station near Post Falls.

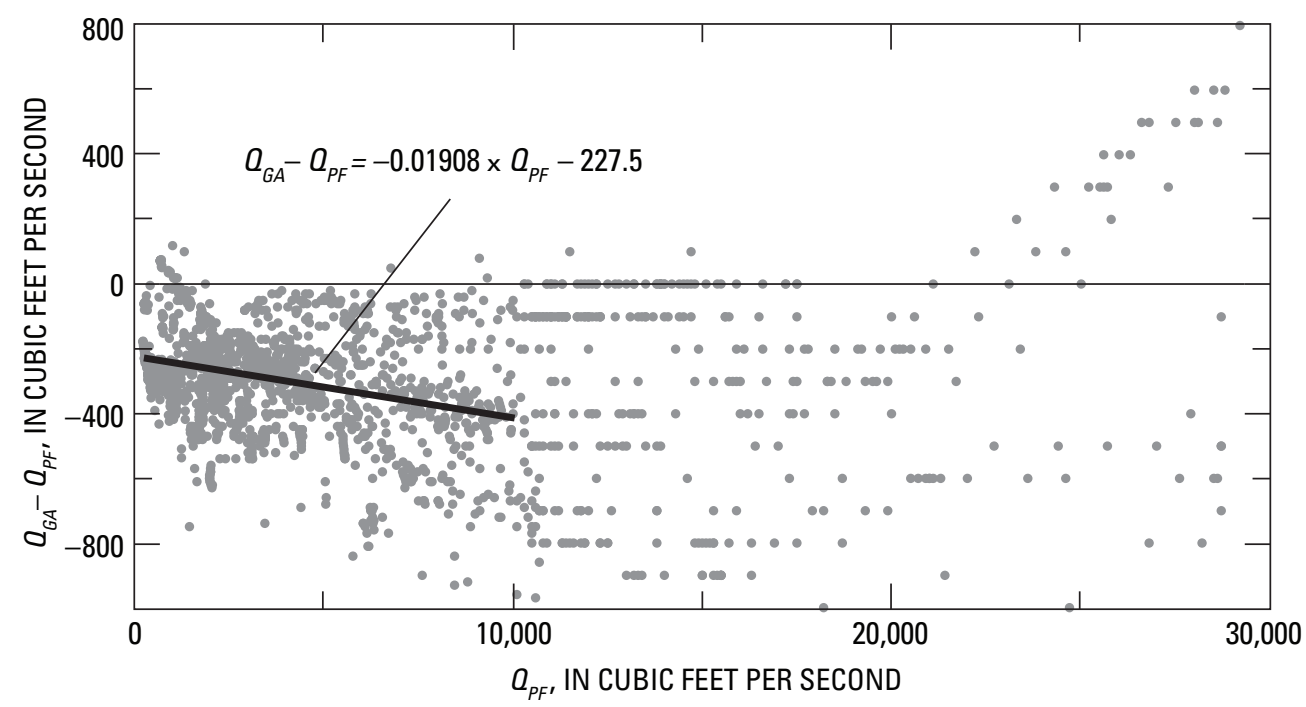

B. Daily streamflow gain (positive value) or loss (negative value) on the Spokane River between gaging stations near Post Falls $\left(Q_{P F}\right)$ and at Greenacres $\left(Q_{G A}\right)$ and streamflow at gaging station near Post Falls.

Figure 21. Streamflow gains or losses between the various gaging stations and streamflow at the gaging station near Post Falls, Spokane Valley-Rathdrum Prairie aquifer, Washington and Idaho. 


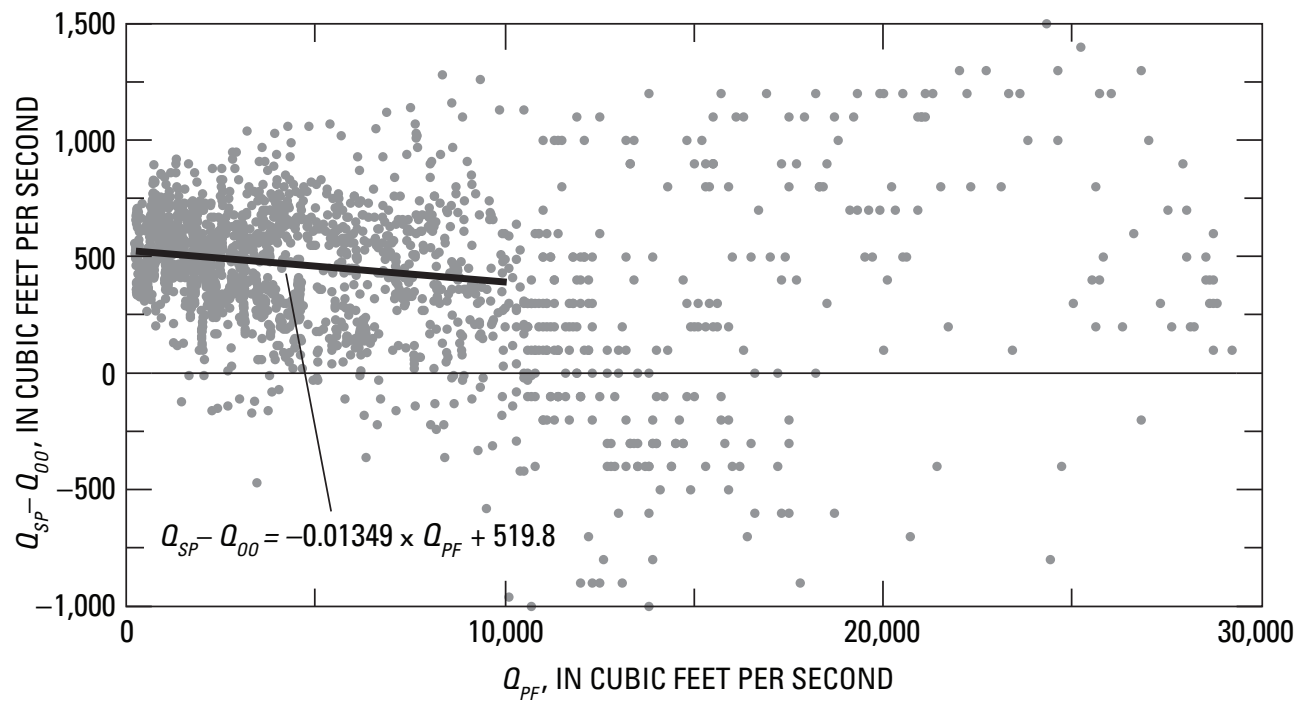

C. Daily streamflow gain (positive value) or loss (negative value) on the Spokane River between gaging stations near Otis Orchards $\left(Q_{o O}\right)$ and at Spokane $\left(Q_{S P}\right)$ and streamflow at gaging station near Post Falls $\left(Q_{P F}\right)$.

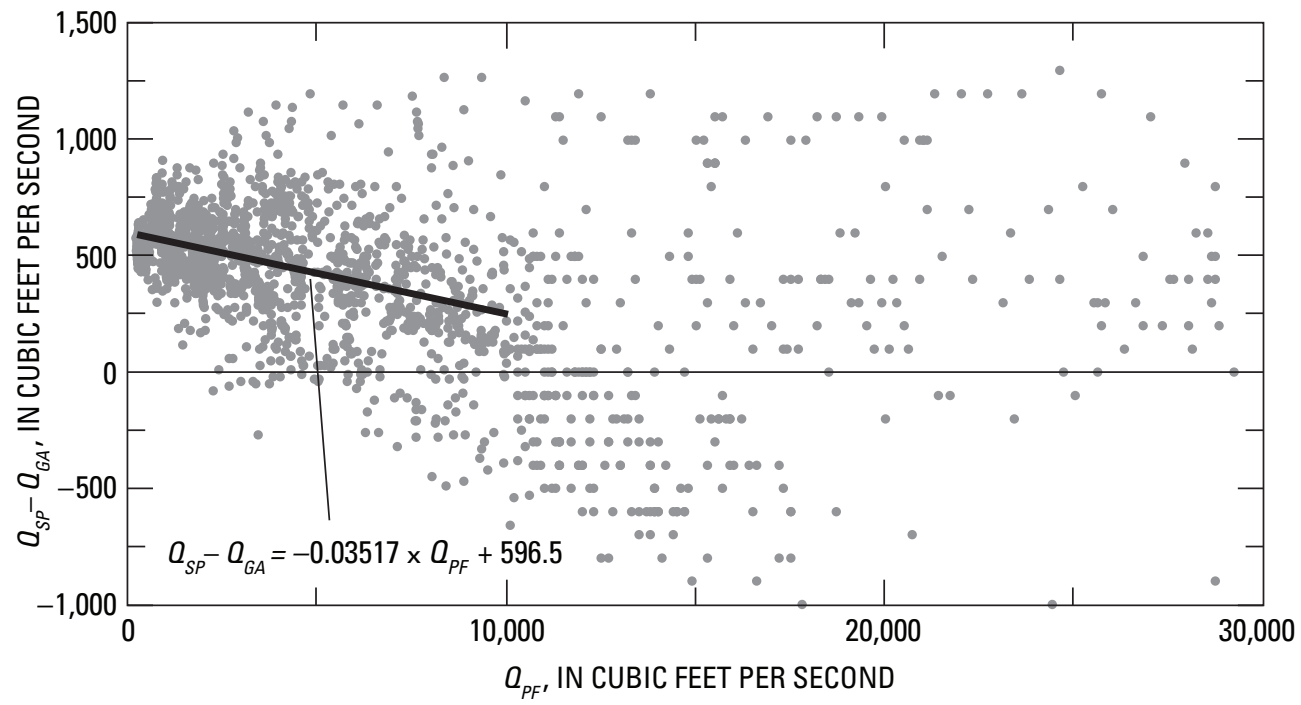

D. Daily streamflow gain (positive value) or loss (negative value) on the Spokane River between gaging stations at Greenacres $\left(Q_{G A}\right)$ and at Spokane $\left(Q_{S P}\right)$ and streamflow at gaging station near Post Falls $\left(Q_{P F}\right)$.

Figure 21.-Continued. 


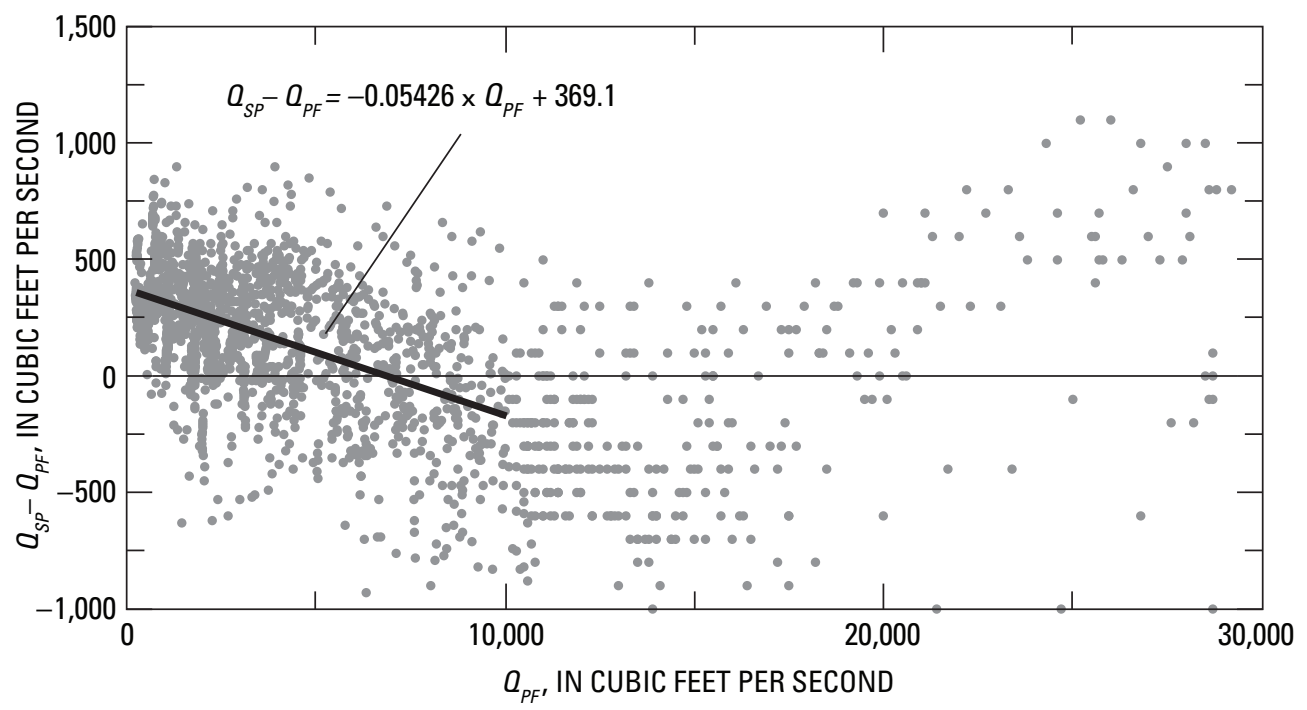

$\boldsymbol{E}$. Daily streamflow gain (positive value) or loss (negative value) on the Spokane River between gaging stations near Post Falls $\left(Q_{P F}\right)$ and at Spokane $\left(Q_{S P}\right)$ and streamflow at gaging station near Post Falls.

Figure 21.-Continued.

\section{Ground-Water Levels and Movement}

Campbell (2005) constructed a map of ground-water levels in the SVRP aquifer on the basis of water levels measured in 268 wells during September 2004. An updated version of the ground-water level map that takes into account more recent information, such as updated altitudes of well sites and the base of the aquifer, is shown in figure 22. Notable features of the water-level map include the relatively flat hydraulic gradient in southern Rathdrum Prairie and the steeper gradients along the aquifer margins and in side valleys. On the Washington side of the aquifer, the hydraulic gradient tends to increase from east to west. In Hillyard Trough and the Little Spokane River Arm, water levels are shown for the upper unit. Too few data are available to construct a map of hydraulic head in the lower unit.

The generalized direction of ground-water flow is shown in figure 22. Ground water flows from northern Rathdrum Prairie through West Channel and Ramsey (Middle) Channel into southern Rathdrum Prairie. Flow through Chilco Channel probably is small because of the small saturated thickness in the channel. From southern Rathdrum Prairie, ground water flows toward the west through Spokane Valley to the Spokane area, where the flow bifurcates. Part of the flow moves through Trinity Trough into the Western Arm of the aquifer. And part moves to the north into Hillyard Tough and finally to the west into the Little Spokane River Arm.
During the summer of 2004, a network of 56 wells was established to measure ground-water levels in the study area (fig. 23, table 7). Measurements were made manually about once a month. Pressure transducers were installed in 8 of the 56 wells to automatically record water levels once an hour. Additional water-level data for certain wells in the network also are available from previous studies. Water levels measured during 2000 and 2001 by Caldwell and Bowers (2003) are available for 11 wells in the vicinity of the Spokane River. Historical water-level data dating back to 1993 and earlier are available for four wells in the network.

Data from the well network indicate that ground-water level fluctuations are characteristic of different parts of the aquifer. For example, in Spokane Valley, ground-water levels are strongly controlled by stage on the Spokane River. The water level in well 60 and the stage on the Spokane River at the gaging station near Otis Orchards from June 2004 to December 2005 are shown in figure 24. To facilitate visual comparison, the well hydrograph is plotted with respect to the vertical axis on the left, and the stage on the Spokane River is plotted with respect to the vertical axis on the right. Individual peaks in the river stage during the high-flow period from December 2004 to June 2005 correspond closely to individual peaks in the well hydrograph. 


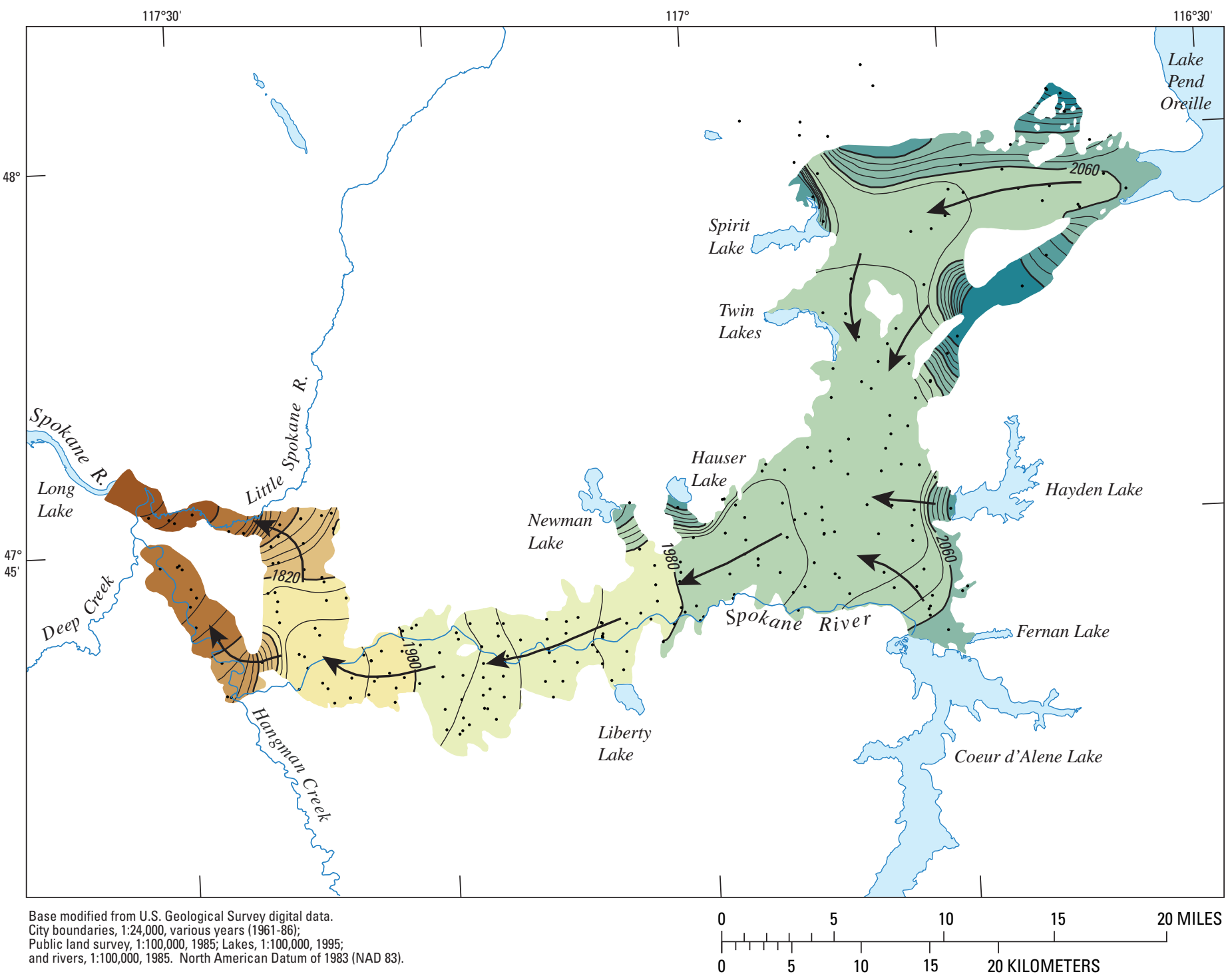

EXPLANATION

Altitude of water level, in feet, of the Spokane ValleyRathdrum Prairie aquifer, September 2004-

Datum is North American Vertical Datum of 1988

\begin{tabular}{|c|c|}
\hline 2,220 to 2,300 & 1,820 to 1,900 \\
\hline 2,140 to 2,220 & 1,740 to 1,820 \\
\hline 2,060 to 2,140 & 1,660 to 1740 \\
\hline 1,980 to 2,060 & 1,580 to 1,660 \\
\hline 1,900 to 1,980 & 1,500 to 1,580 \\
\hline
\end{tabular}

— 1400 - Water-level contour-Shows altitude of water level, September 2004. Contour interval is 20 feet. Datum is North American Vertical Datum of 1988

$\leftarrow \quad$ Generalized direction of ground-water flow

Site of water-level measurement

Figure 22. Ground-water levels for the Spokane Valley-Rathdrum Prairie aquifer, Washington and Idaho, September 2004 (revised after Campbell, 2005). 


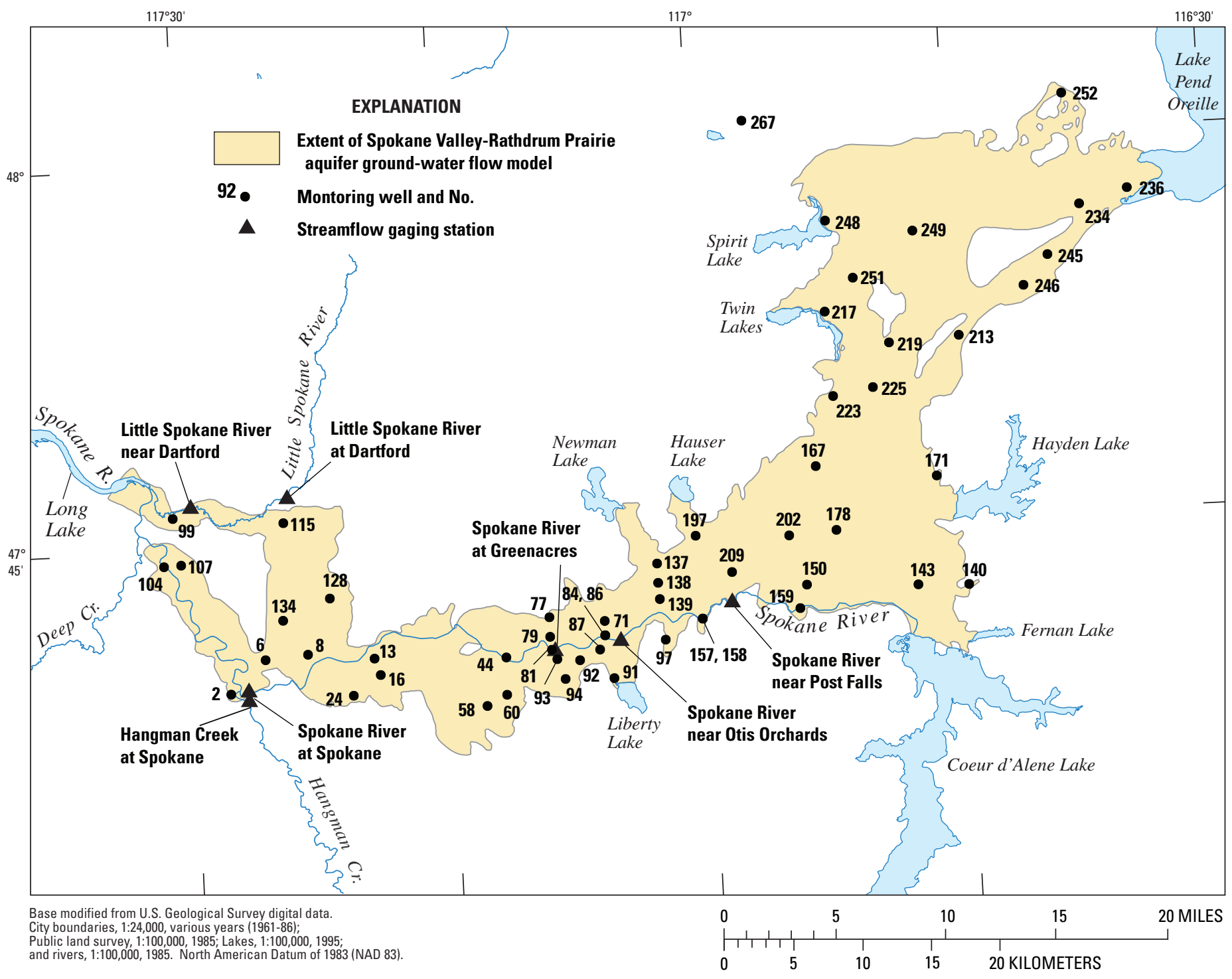

Figure 23. Locations of monitoring wells in the Spokane Valley-Rathdrum Prairie aquifer, Washington and Idaho.

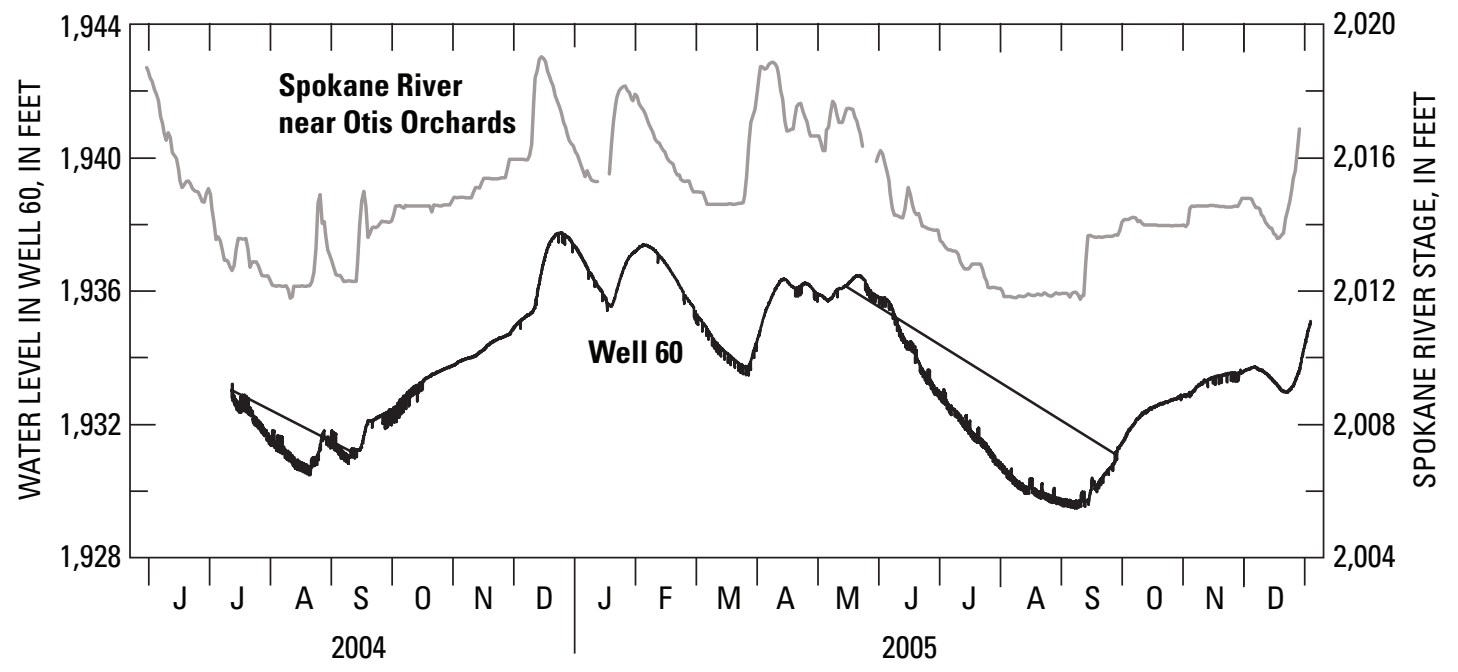

Figure 24. Water level in well 60 and stage on the Spokane River at the gaging station near Otis Orchards, Spokane Valley-Rathdrum Prairie aquifer, Washington and Idaho. 
Table 7. Physical data for wells in water-level monitoring network, Spokane Valley-Rathdrum Prairie aquifer, Washington and Idaho.

[Abbreviations: USGS, U.S. Geological Survey; NAD 83, North American Datum of 1983; NAVD 88, North American Vertical Datum of 1988; ft, foot]

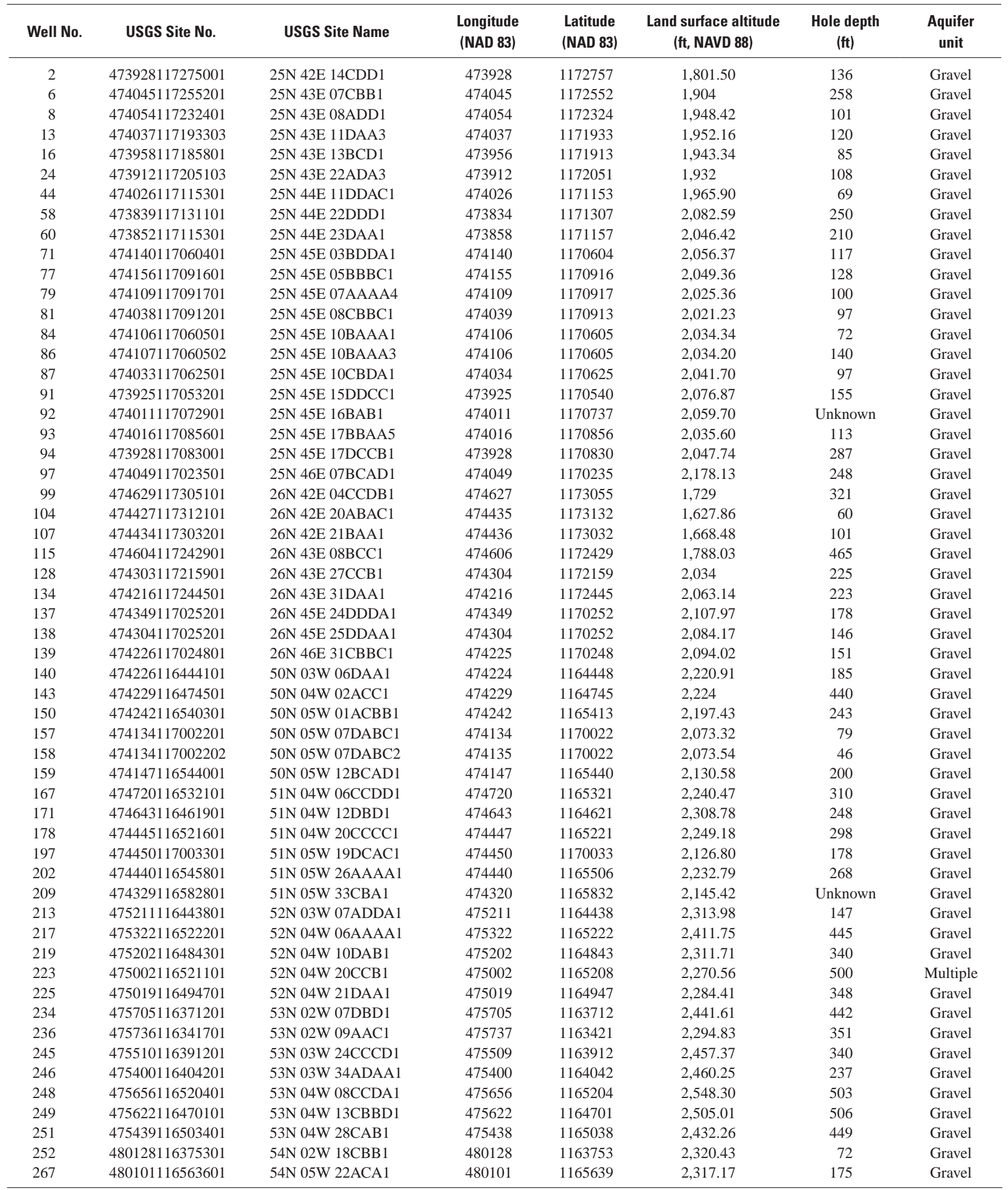


In Hillyard Trough, ground-water level fluctuations are less dynamic than those in Spokane Valley. The water level in well 128 and the stage on the Spokane River at the gaging station at Spokane are shown in figure 25. The rise and fall of the well hydrograph are more gradual than the rise and fall of the river stage because wells in Hillyard Trough are farther from the Spokane River than wells in Spokane Valley.

In the north part of Western Arm, ground-water levels are strongly controlled by the level of Nine Mile Reservoir. Water levels in wells 104 and 107 and the level of Nine Mile Reservoir are shown in figure 26. Wells 104 and 107 are located, respectively, on the west and east sides of Nine Mile Reservoir. The rise and fall of the well hydrographs are closely correlated with the rise and fall of the reservoir. During periods when the level of the reservoir is constant, the water level in well 107 is nearly identical to level of the reservoir, but the water level in well 104 is about $0.5 \mathrm{ft}$ above the level of the reservoir. This indicates that ground water discharges from the SVRP aquifer to Nine Mile Reservoir.
In northern Rathdrum Prairie, ground-water level fluctuations are substantially different from those in Spokane Valley. Long-term water levels in wells 92, 209, and 251 for 1990-2005 are shown in figure 27. Well 92 is in Spokane Valley. The hydrograph of well 92 is similar to the hydrograph of well 60 (fig. 24) — the water level exhibits multiple peaks that correlate to peaks in the stage on the Spokane River during winter and spring. By contrast, well 251 is in northern Rathdrum Prairie. The hydrograph of well 251 is controlled primarily by recharge from precipitation. Although most of the precipitation infiltrates into the land surface during winter and spring, the long transmission time from land surface to the water table at depths of 400-500 ft caused the hydrograph to peak in July and August. Well 209 is in the transition zone between southern Rathdrum Prairie and Spokane Valley. The hydrograph of well 209 exhibits characteristics that are intermediate between those of wells 92 and 251 .
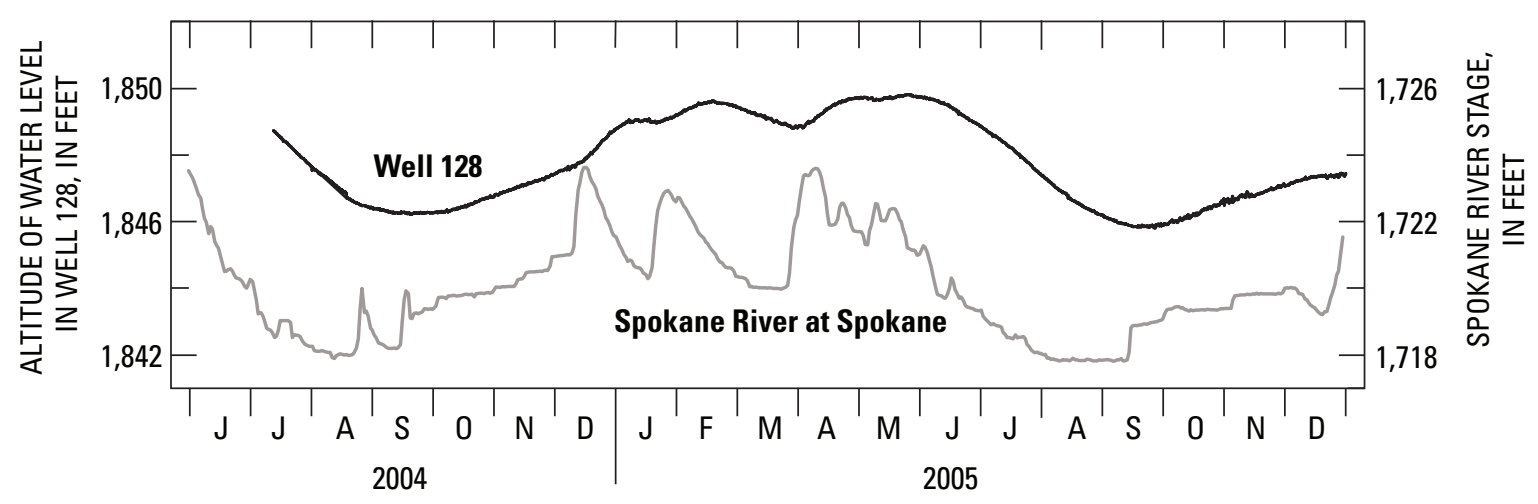

Figure 25. Water level in well 128 and stage on the Spokane River at the gaging station at Spokane, Spokane Valley-Rathdrum Prairie aquifer, Washington and Idaho.

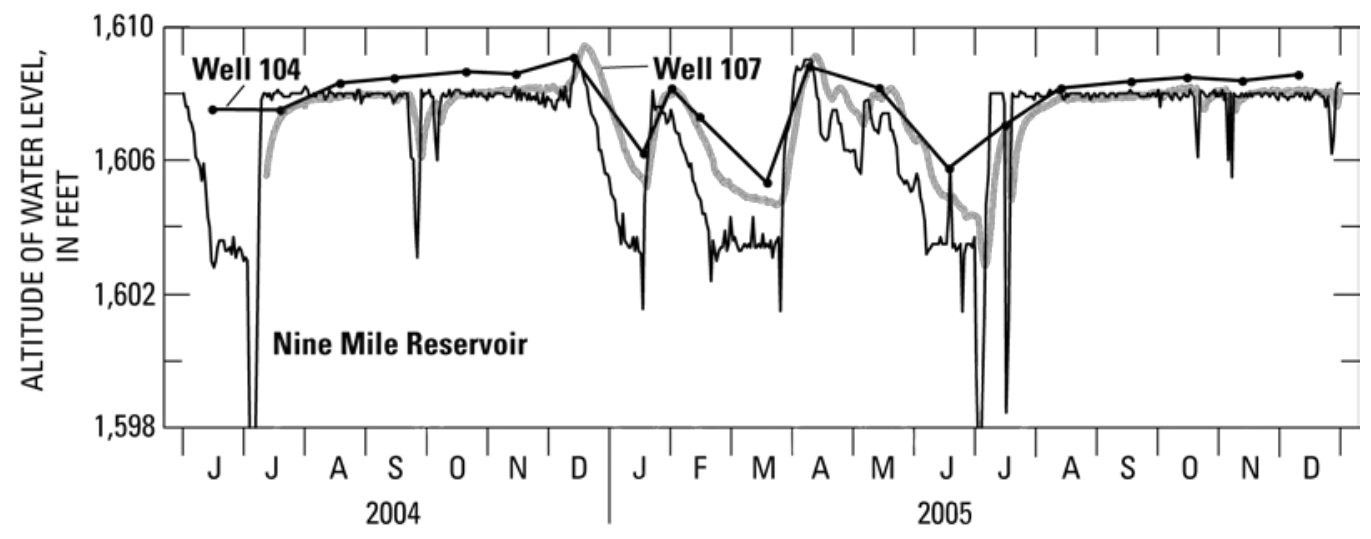

Figure 26. Water levels in wells 104 and 107 and in Nine Mile Reservoir, Spokane Valley-Rathdrum Prairie aquifer, Washington and Idaho. 

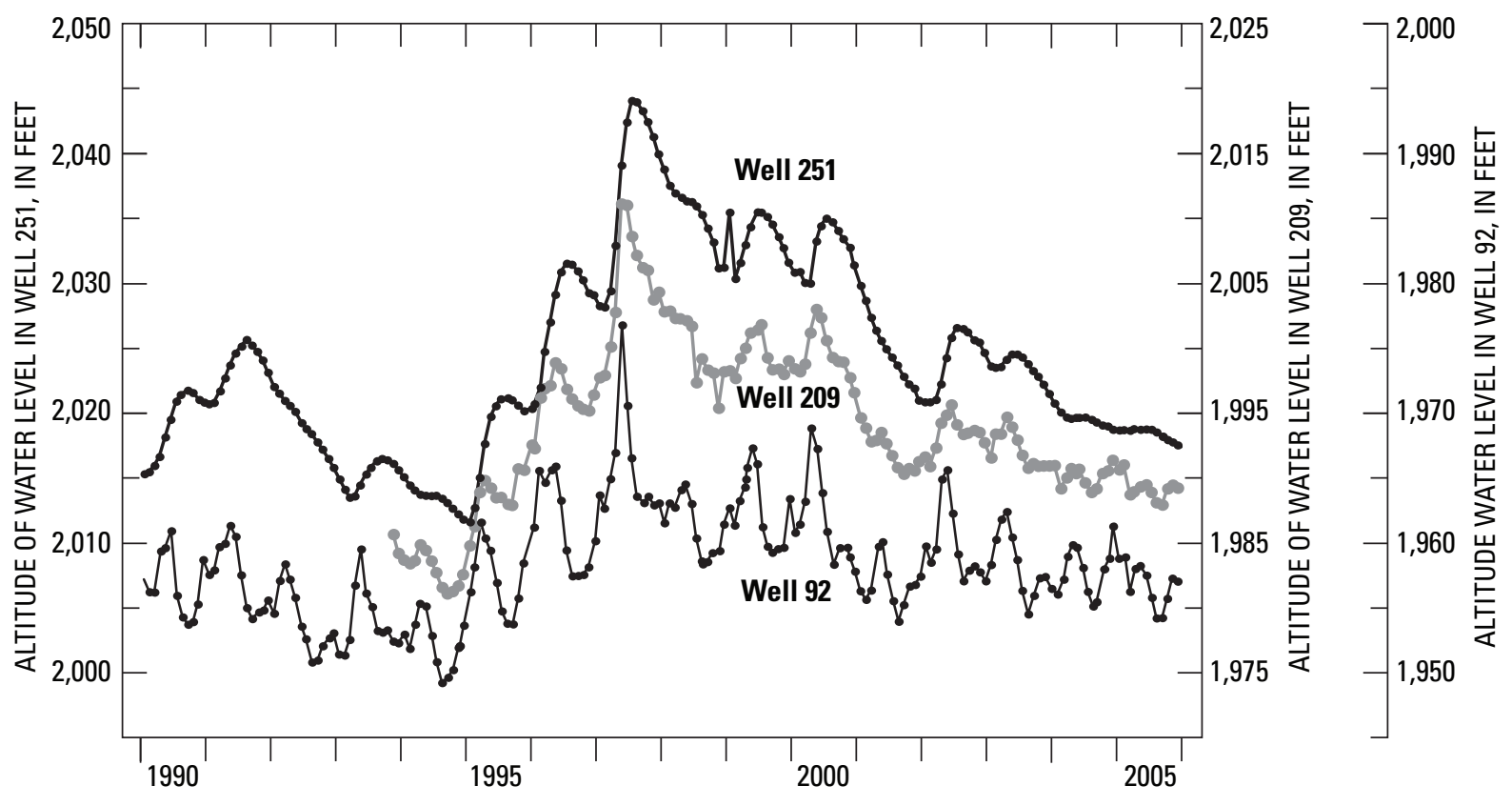

Figure 27. Water levels in wells 92, 209, and 251, Spokane Valley-Rathdrum Prairie aquifer, Washington and Idaho.

The falling limbs of the hydrograph of well 251 are more gradual then the falling limbs of the hydrograph of well 92 (fig. 27). This may be explained by the fact that ground water in northern Rathdrum Prairie must discharge through West Channel and Ramsey Channel, which can constrict groundwater flow. During several years of higher-than-average recharge, such as from 1995 to 1997, ground-water levels in northern Rathdrum Prairie can exhibit an increasing trend over several years. Conversely, during several years of lower-thanaverage recharge, such as from 2000 to 2005, ground-water levels in northern Rathdrum Prairie can exhibit a declining trend over several years.

In the vicinity of Lake Pend Oreille, ground-water levels in the SVRP aquifer are strongly controlled by the lake level. The hydrographs of wells 234 and 236 and the level of Lake Pend Oreille are shown in figure 28. The lake level is maintained at about 2,066 ft during the summer and at a lower level during the rest of the year. This lake level signal is exhibited by the hydrographs of wells 234 and 236. The water levels shown in figure 28 also indicate that flow is from the lake toward wells 234 and 236.

In the vicinity of Coeur d'Alene Lake and Post Falls, ground-water levels do not show a clear relation to the level in the lake (and the arm of the Spokane River above Post Falls). The hydrographs of wells 143 and 159 and the level of Coeur d'Alene Lake are shown in figure 29. Note that the lake level is about $100 \mathrm{ft}$ higher than the water levels in the wells. From June to mid-September, the lake level is maintained at about 2,132 ft. From mid-September to December, the gates at Post
Falls Dam are opened incrementally to lower the lake to its natural autumn level. From December to June, the dam gates usually are left open to allow the lake level to rise and fall in response to inflows from storms and snowmelt. The water levels in wells 143 and 159 do not follow the lake level. In well 143, the water level peaks in November when the lake level is declining. In well 159 , the water level peaks in July when the lake level is high. Then, for the next 1 to 2 months, the water level declines when the lake level is constant. These fluctuations in ground-water levels are not explained readily by a simple conceptualization of lake-aquifer interaction in which ground-water levels near the lake are expected to rise in response to greater subsurface leakage from the lake during times of high lake levels, and fall in response to less subsurface leakage from the lake during times of low lake levels.

Water levels in wells along the perimeter of the SVRP aquifer generally are not indicative of hydrologic conditions in the main part of the aquifer. Along the perimeter of the aquifer, bedrock is close to land surface, the saturated zone is thin, hydraulic conductivity tends to be low, and groundwater levels can be tens to more than $100 \mathrm{ft}$ higher than in the main part of the aquifer. In addition, ground-water levels along the perimeter can rise and decline abruptly in response to episodic inflows from surrounding uplands. The effects of these inflows typically are damped out in the main part of the aquifer. The hydrograph of well 245, which is located near the east boundary of northern Rathdrum Prairie, and the hydrograph of well 249, which is located in the central part of northern Rathdrum Prairie, are shown in figure 30. 


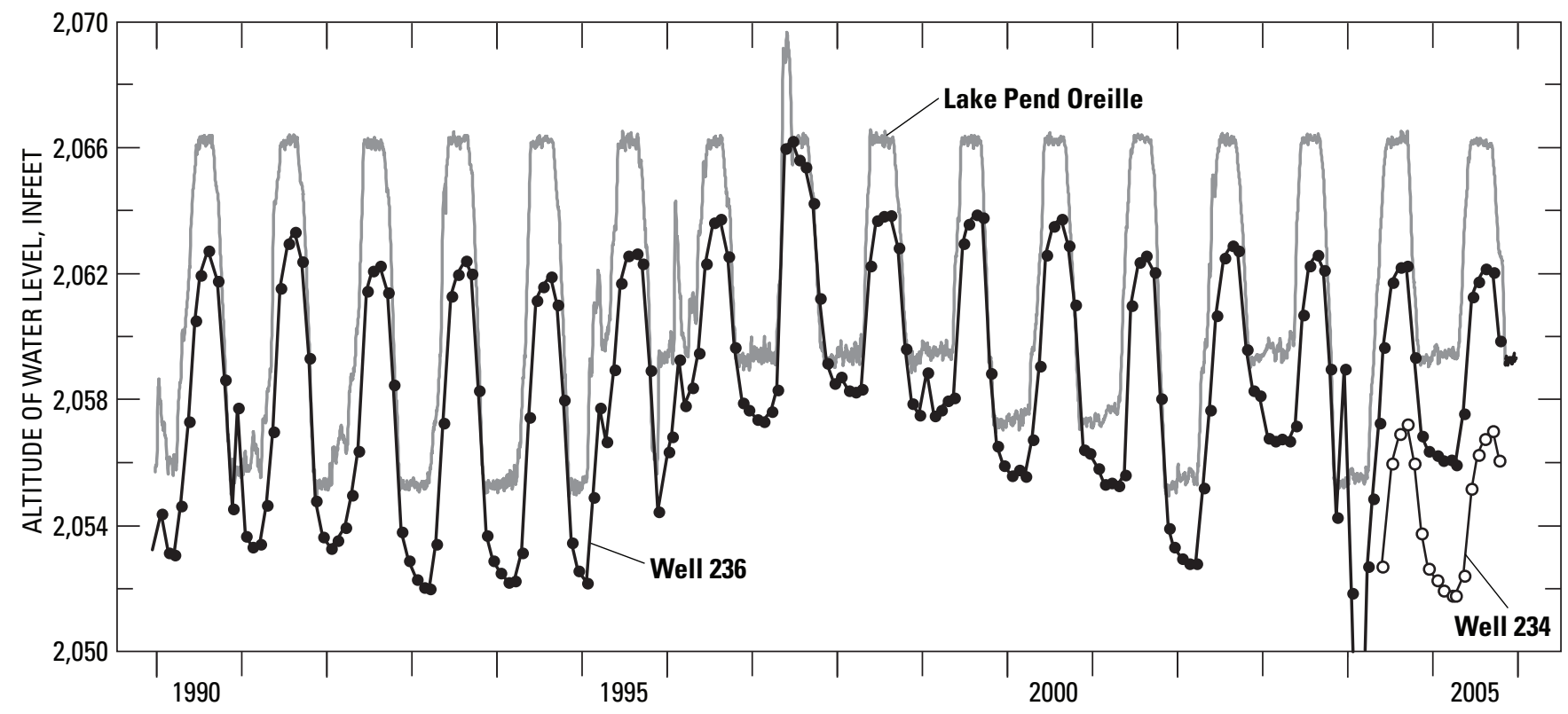

Figure 28. Water levels in wells 234 and 236 and in Lake Pend Oreille, Spokane Valley-Rathdrum Prairie aquifer, Washington and Idaho.

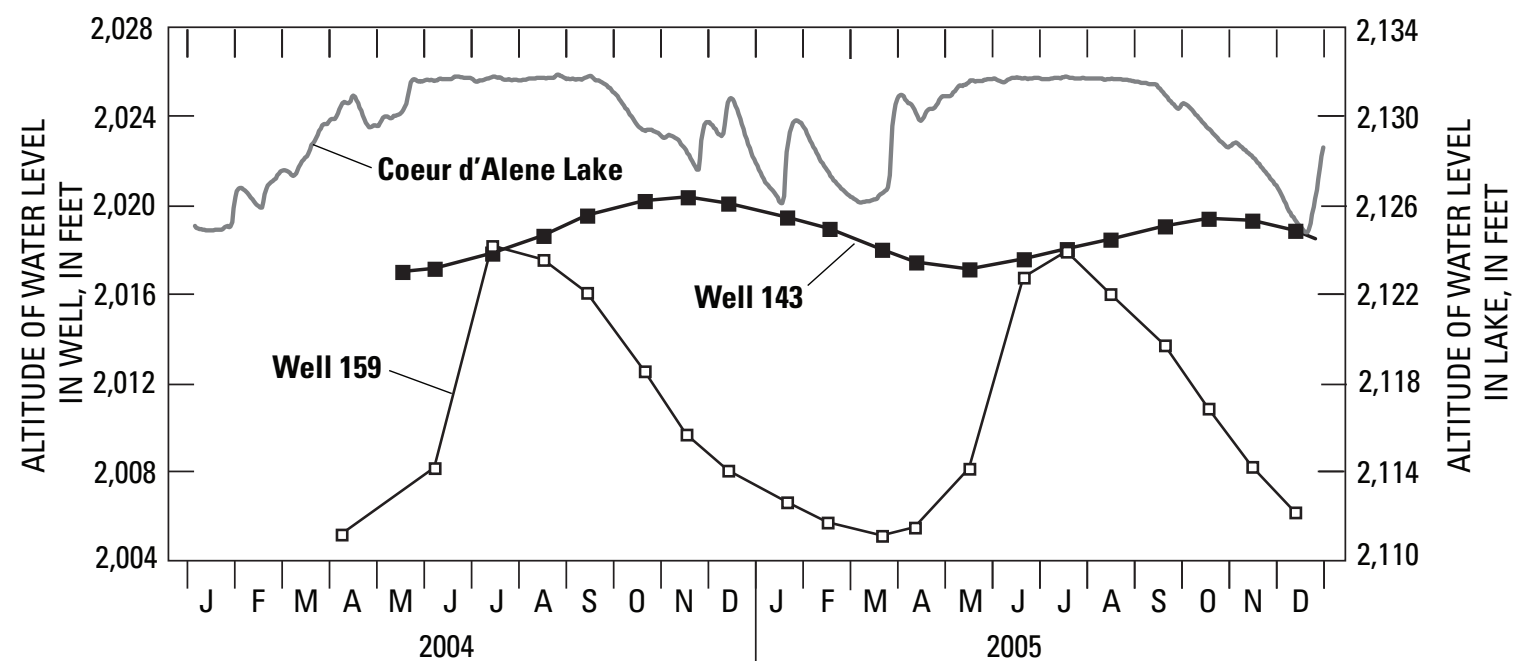

Figure 29. Water levels in wells 143 and 159 and in Coeur d'Alene Lake, Spokane ValleyRathdrum Prairie aquifer, Washington and Idaho. 
The water level in well 245 is about $150 \mathrm{ft}$ higher than the water level in well 249. During the period of record shown in figure 30 , the water level is relatively stable in the central part of northern Rathdrum Prairie. However, the water level near the east boundary indicates a substantial rise and fall during the winter and spring in response to storm and snowmelt runoff.

Along the losing segment of the Spokane River from the gaging stations near Post Falls to at Greenacres, the riverbed is above the regional water table and water leaks out of the river to recharge the aquifer. Caldwell and Bowers (2003, p. 18-19 and fig. 7) noted that a narrow ground-water mound can develop beneath the river as a result of vertical infiltration from the river. A well located close to the riverbank might penetrate the ground-water mound and encounter a water level that is substantially higher than the water level that predominates in regions away from the river. Wells 84, 157, and 158 in the well network appear to fit that description. For example, from June 2004 to December 2005, the average water level in well 84 is $1,990 \mathrm{ft}$. For the same period, the water levels in wells 71 and 87, both about 3,500 ft from well 84 and the Spokane River (fig. 23), are, respectively, 1,963 and 1,961 ft. The water levels in wells 71 and 87 are consistent with the regional trend of the water table, but the water level in well 84 likely characterizes the local ground-water condition immediately beneath the Spokane River.

During April 2006, synoptic water-level measurements were made in the same 268 wells used for the September
2004 synoptic water-level measurements (Campbell, 2005). The two water-level data sets provide an opportunity to compare spring and autumn water levels throughout the SVRP aquifer. The change in water level from September 2004 to April 2006 is shown in figure 31. At each well, the change is computed as the water level in April 2006 minus the water level in September 2004. A positive change indicates a rise in water level from September 2004 to April 2006. A negative change indicates a decline in water level from September 2004 to April 2006. Excluded from figure 31 are wells that were pumped prior to or during either synoptic measurement session.

The water-level changes shown in figure 31 display many of the water-level characteristics discussed in the preceding paragraphs. For the most part, water levels rose in the aquifer in response to recharge from precipitation and river infiltration during the winter of 2005-06 and the spring of 2006. However, exceptions occur in the vicinity of Lake Pend Oreille and in the vicinity of Coeur d'Alene Lake. The level of Lake Pend Oreille is lower in spring than in autumn. Figure 31 shows that ground-water levels in the vicinity of Lake Pend Oreille declined from September 2004 to April 2006. The magnitude of the water-level decline is largest close to the lake and decreases with distance away from the lake. The areal extent of the decline indicates that the lake level could influence ground-water levels over a distance from the lake to about halfway between Lake Pend Oreille and Spirit Lake.

In the vicinity of Coeur d'Alene Lake, ground-water levels also declined from September 2004 to April 2006.

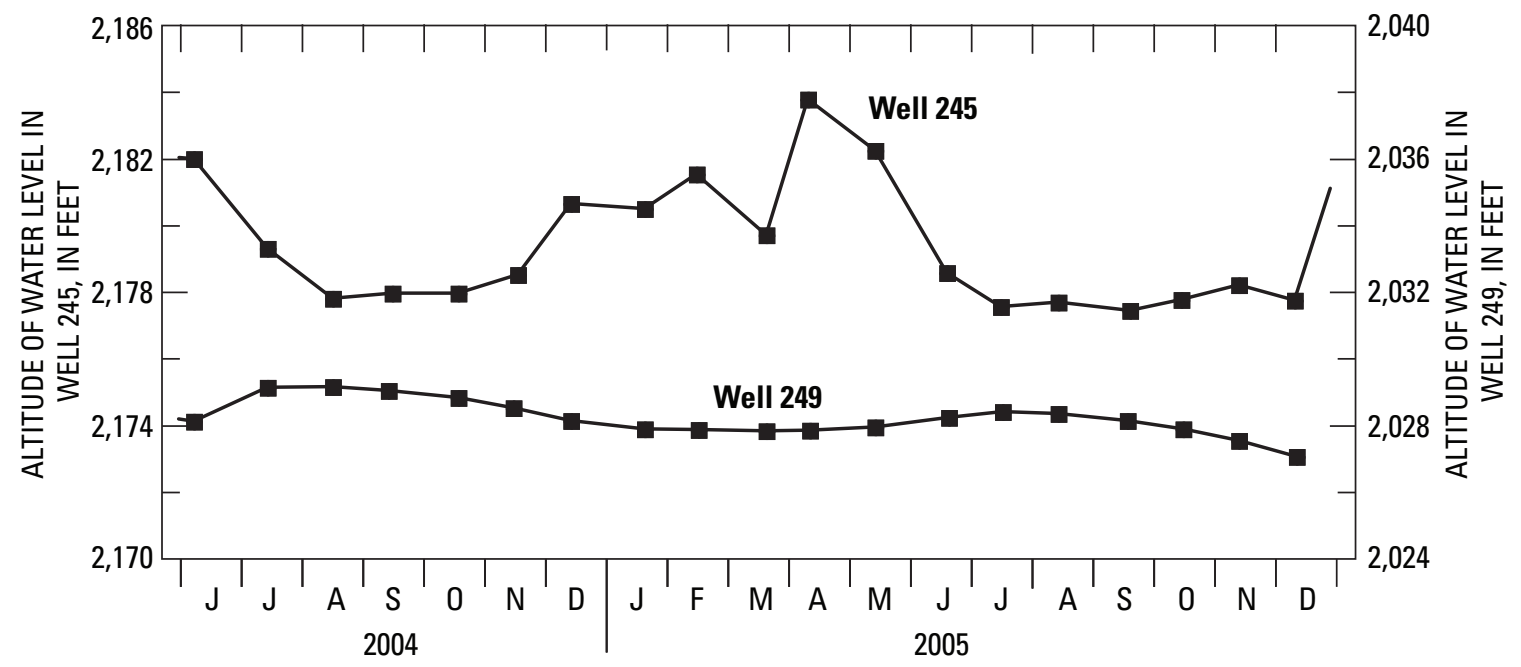

Figure 30. Water levels in wells 245 and 249, Spokane Valley-Rathdrum Prairie aquifer, Washington and Idaho. 


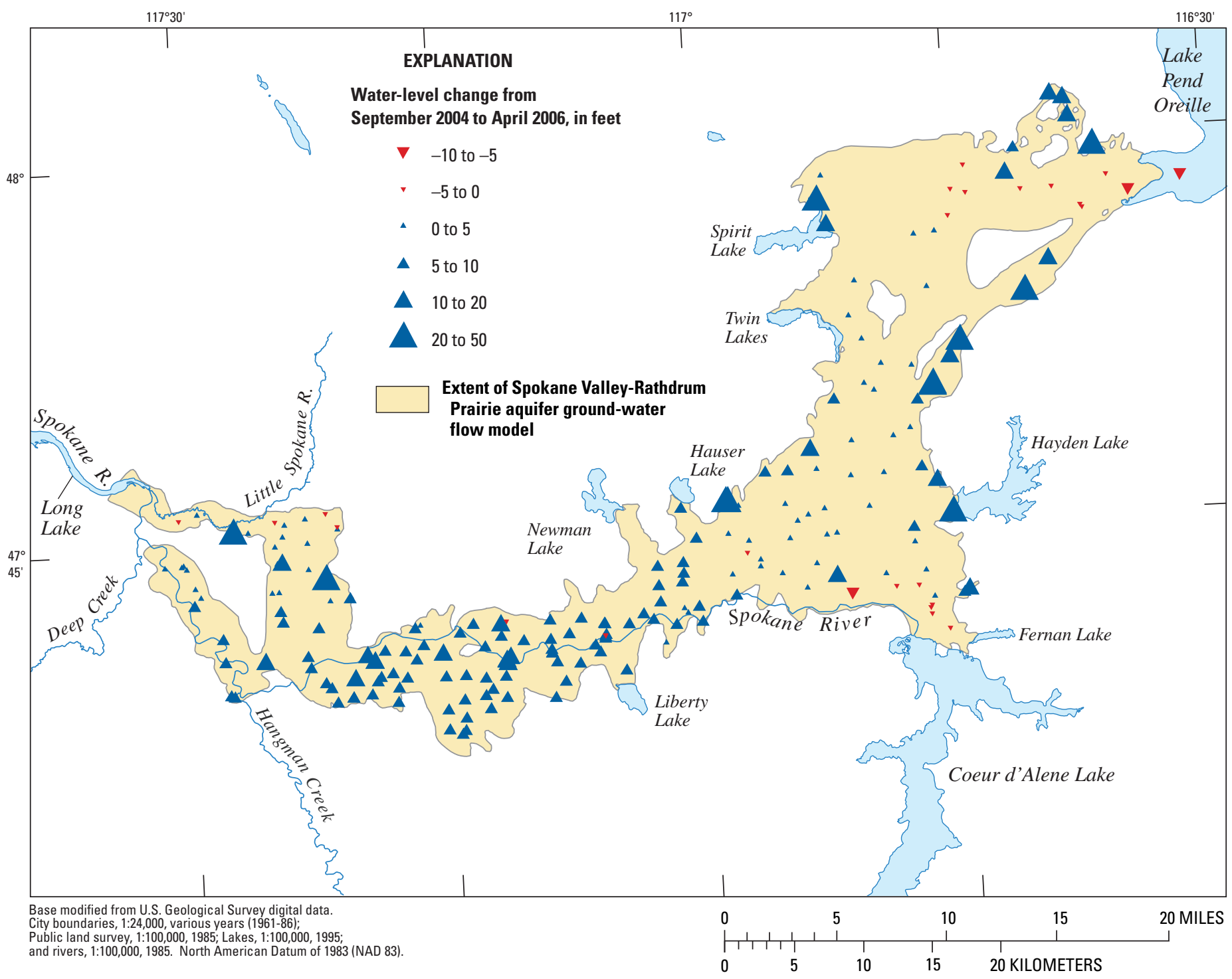

Figure 31. Changes in water levels, Spokane Valley-Rathdrum Prairie aquifer, Washington and Idaho, September 2004 to April 2006.

September 2004 is the end of the summer period when Coeur d'Alene Lake was maintained at about 2,132 ft. During April 2006, the lake level rose from about 2,129 to 2,132 ft. However, as discussed previously, the ground-water levels in the vicinity of Coeur d'Alene Lake do not show a clear relation to the lake level. Therefore, it is difficult to provide a clear explanation for the decline in ground-water levels in the vicinity of the lake from September 2004 to April 2006.
Along the margins of Rathdrum Prairie, water levels rose by tens of feet. By contrast, in the central part of Rathdrum Prairie, the water level rose by a few feet. The data support the concept that water levels along the aquifer margins are strongly controlled by inflows from adjacent uplands and tributary basins. The large fluctuations in water levels along the aquifer margins are damped out in the central part of the aquifer. 
The water-level rise in Spokane Valley is substantially larger than the water-level rise in Rathdrum Prairie (excluding the wells along the prairie margins). This is due to the presence of the Spokane River, which is a major source of recharge to Spokane Valley. In addition, the greater depths to the water table in Rathdrum Prairie require a longer time for precipitation infiltration to reach the water table. Thus, water-level rises in Rathdrum Prairie generally lags behind the water-level rise in Spokane Valley.

\section{Ground-Water Flow Model}

The ground-water flow model known as MODFLOW2000 (Harbaugh and others, 2000) is used to simulate ground-water flow in the SVRP aquifer. MODFLOW-2000 is a computer program that numerically solves the threedimensional ground-water flow equation for a porous medium by using the finite-difference method. The modular design of MODFLOW-2000 uses packages to represent various components of the ground-water flow system, such as recharge, withdrawal from wells, and interactions between the aquifer and surface-water bodies.

\section{Spatial Discretization}

A model grid of 172 rows, 256 columns, and 3 layers is used to represent the SVRP aquifer. In the horizontal direction, each cell has a dimension of 1,320 by $1,320 \mathrm{ft}$. The areal extent of the grid is larger than the model area. The larger grid is intended to accommodate possible enlargements of the model area in future studies. Cells outside the model area are designated as inactive in MODFLOW-2000. The active cells in model layers 1 and 3 and shown in figures 32 and 33 .

Vertically, the SVRP aquifer is represented by either one or three model layers. Except in Hillyard Trough and Little Spokane River Arm, the aquifer is represented by the top model layer (layer 1); cells in model layers 2 and 3 are inactive. In Hillyard Trough and the Little Spokane River Arm, the aquifer is represented by three model layers. Vertical section A-B-C-D in figure 34 shows how the model layers represent the dividing of the aquifer from a single hydrogeologic unit into an upper and a lower unit separated by a clay layer. From A to B, the aquifer exists as a single hydrogeologic unit and is represented solely by model layer 1. Model layers 2 and 3 have zero thicknesses and are designated as inactive. From $\mathrm{B}$ to $\mathrm{C}$, the aquifer exists as a single hydrogeologic unit but is represented by all three model layers. Model layer 2 has a uniform thickness of $1 \mathrm{ft}$, but model layer 3 gradually thickens from B to C. Point C marks the location where the aquifer divides into an upper and a lower unit. From $\mathrm{C}$ to $\mathrm{D}$, model layer 1 represents the upper unit, model layer 2 represents the clay layer, and model layer 3 represents the lower unit. The altitude at the top of the clay layer is set at 1,700 $\mathrm{ft}$ in Hillyard Trough and decreases to 1,500 ft in the Little Spokane River Arm. The thickness of the clay layer is assumed to be $150 \mathrm{ft}$ in both Hillyard Trough and the Little Spokane River Arm. In the input data for MODFLOW-2000, model layer 1 is specified as an unconfined layer. Model layers 2 and 3 are specified as confined layers.

\section{Temporal Discretization}

Ground-water flow in the SVRP aquifer is simulated for September 1990 through September 2005. The simulation period is divided into 181 stress periods of 1 month each. Monthly stress periods are needed to simulate the dynamic interaction between the aquifer and the Spokane River as shown by the hydrograph in figure 24 . Each stress period consists of one time step. Using one time step per stress period was determined to be adequate because trial simulations using several time steps per stress period yielded essentially the same results.

Because the distribution of heads in the aquifer is unknown at the beginning of the simulation period, the initial heads are computed assuming a steady-state ground-water flow system during the first stress period (September 1990). The heads simulated during the first stress period serves as the initial conditions for the rest of the transient simulation. In reality, flow in the aquifer is not at steady state during September 1990, and the simulated heads for that month do not accurately represent the actual heads in the aquifer. To eliminate the effects of this error, the first 5 years of the simulation is considered a start-up period. No attempt is made to fit simulated quantities to measured quantities during the start-up period. Instead, hydrologic data from October 1995 to September 2005 are used for model calibration. The calibrated model is expected to produce simulated conditions at the end of the start-up period (October 1995) that are close to the corresponding actual conditions in the aquifer, because the error caused by the assumed initial conditions would have dissipated. 


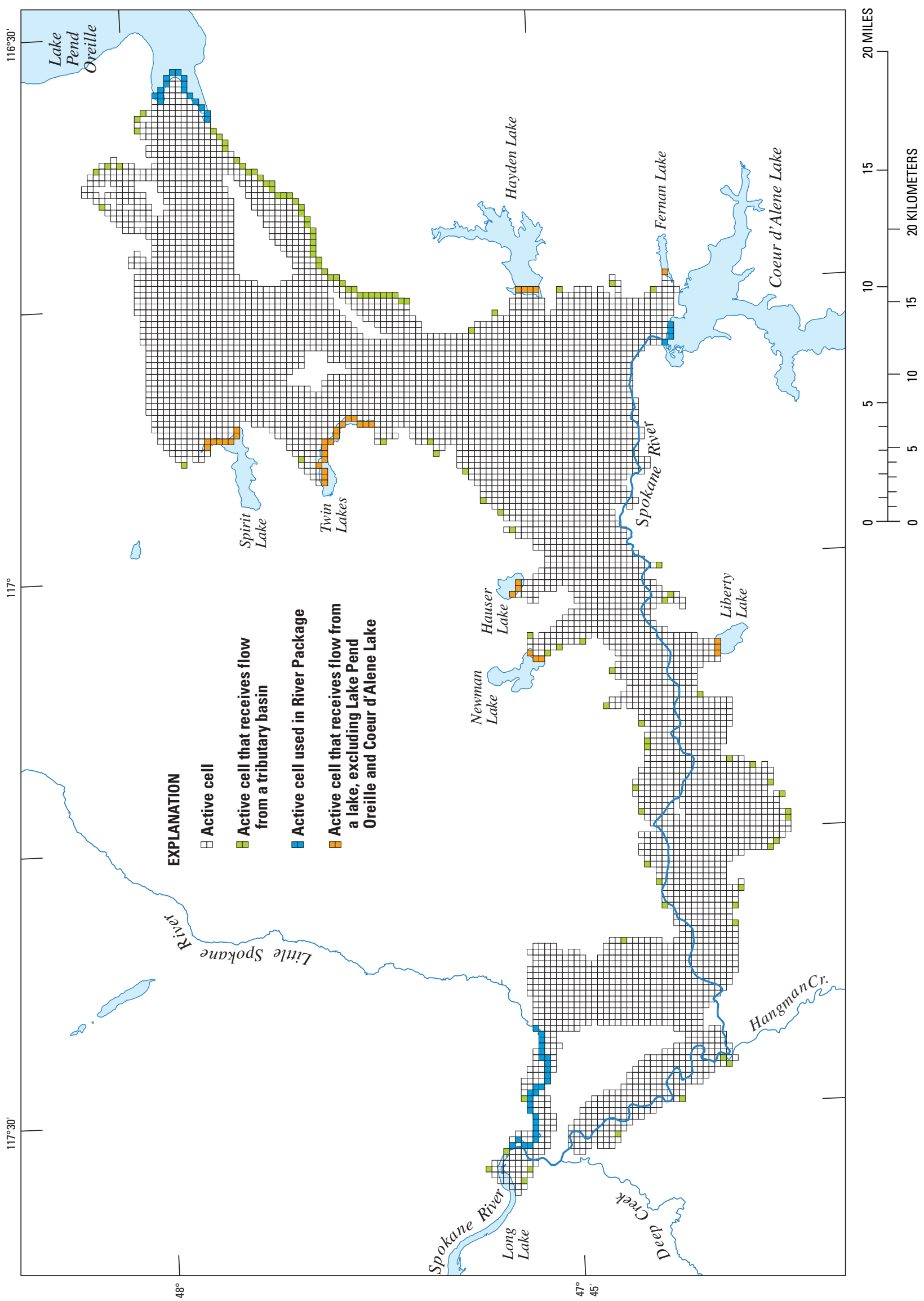

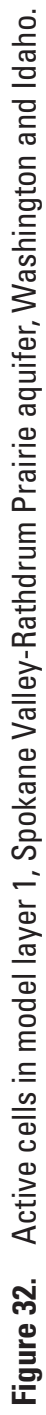




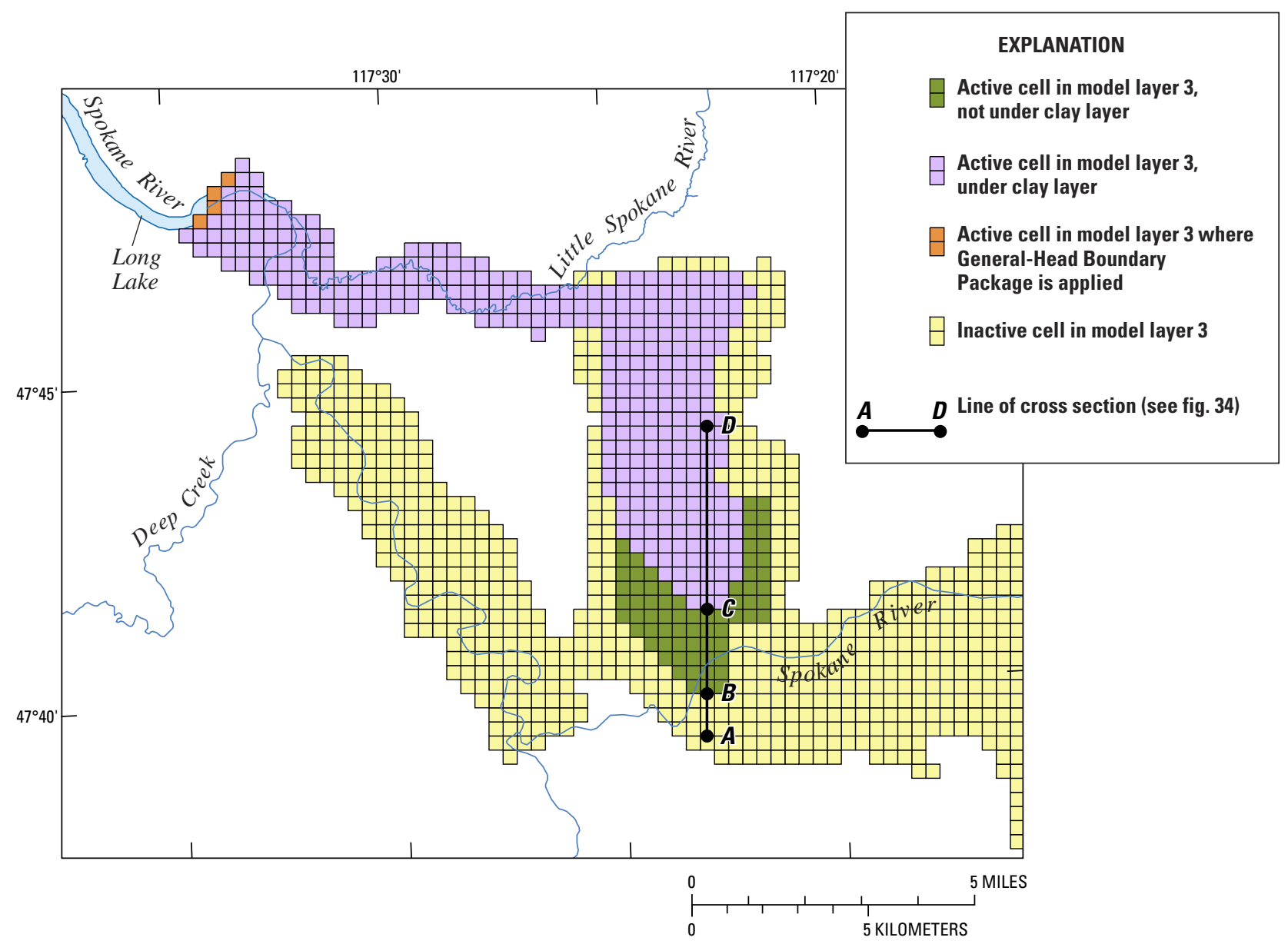

Figure 33. Active cells in model layer 3, Spokane Valley-Rathdrum Prairie aquifer, Washington and Idaho.

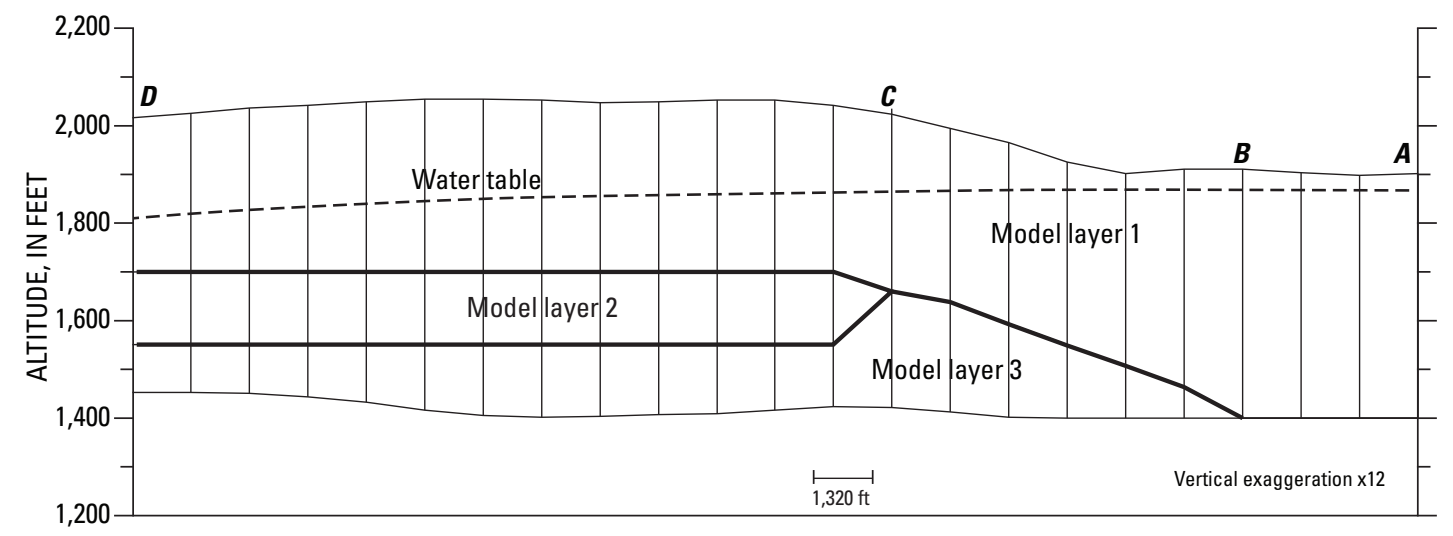

Figure 34. Vertical section A-B-C-D showing how model layers represent the dividing of the aquifer from a single hydrogeologic unit into an upper and lower unit separated by a clay layer, Spokane Valley-Rathdrum Prairie aquifer, Washington and Idaho. 


\section{Boundary Conditions and Implementation of MODFLOW Packages}

A no-flow boundary is specified on the bottom of the model domain. Along the sides of the model domain, the no-flow boundary is specified except for locations where the aquifer receives inflow from tributary basins and lakes and where ground water exits the lower unit at the west end of the Little Spokane River Arm. Boundary conditions other than the no-flow boundary are implemented in the model using various MODFLOW packages. These packages represent inflow and outflow components discussed previously in the sections, "Inflows to Aquifer" and "Outflows from Aquifer."

\section{Recharge Package}

The Recharge Package is used to simulate recharge from precipitation. Recharge is applied to the top model layer. For each active cell and for each stress period (that is, for each month), the recharge is the precipitation infiltration flux (in units of feet per day) that enters the ground-water table. This recharge is derived from (1) precipitation that infiltrates into permeable land surfaces and (2) precipitation runoff from impermeable land surfaces to recharge wells, infiltration basins, or adjacent permeable surfaces.

\section{Well Package}

The Well Package is used to simulate withdrawals from wells, return percolation from irrigation, and effluent from septic systems. For each active cell and for each stress period, a positive well flow value (in units of cubic feet per day) indicates a volumetric recharge rate, and a negative well flow value indicates a volumetric withdrawal rate. In the model, the well flow value for each cell is the net result of well withdrawals, return percolation from irrigation, and effluent from septic systems. For example, within a water purveyor service area, a cell that contains a water-supply well has a large negative well flow value, which is dominated by the well withdrawal rate. By contrast, a cell that does not contain a water-supply well has a small positive well flow value, which represents return percolation from landscape irrigation.

\section{Flow and Head Boundary Package}

The Flow and Head Boundary Package (Leake and Lilly, 1997) is used to simulate flows to the SVRP aquifer from tributary basins and from all lakes except Lake Pend Oreille and Coeur d'Alene Lake. For each tributary basin that drains to the aquifer (fig. 10), flow from the basin is assigned as specified flow to the active cell that contains or is closest to the outflow point. An exception to this procedure is made along the east margin of northern Rathdrum Prairie. In that area, the saturated zone is a thin layer overlying bedrock. If flow from the tributary basin is applied to a single cell, a very large buildup in head would result. To avoid this situation, flow is distributed uniformly among active cells along the model boundary. The cells that receive flow from tributary basins are shown in figure 32. For the lakes, flow to the aquifer is distributed uniformly among active model cells along the lakeshore (fig. 32).

\section{River Package}

The River Package is used to simulate the Little Spokane River, Lake Pend Oreille, and Coeur d'Alene Lake. In the River Package, a river reach refers to the section of a river with a model cell. For a river reach, the volumetric flow rate across the riverbed to the underlying model cell is computed as

$$
Q_{r b}=C_{r b}\left(h_{r}-h_{a}\right),
$$

where

$Q_{r b}$ is the flow rate across the riverbed,

$C_{r b}$ is the conductance of the riverbed,

$h_{r}$ is the river stage, and

$h_{a} \quad$ is the hydraulic head in the cell underlying

the riverbed, if the bottom of the

riverbed is below the water table in

the cell, or the altitude of the bottom

of the riverbed, if the bottom of the

riverbed is above the water table in

the cell.

The conductance of the riverbed is given by

$$
C_{r b}=\frac{K_{v} w L}{m},
$$

where
$K_{v} \quad$ is the vertical hydraulic conductivity of the riverbed sediment,
$w$ is the width of the river reach,
$L \quad$ is the length of the river reach, and
$m \quad$ is the thickness of the riverbed sediment.

However, $K_{v}, w, L$, and $m$ are not individually specified in the River Package. Instead, conductance of the riverbed, $C_{r b}$, is specified. Model cells used in the River Package are shown in figure 32 .

To apply the River Package to the Little Spokane River, the following procedure is used to determine the river stage, $h_{r}$. For each stress period, the average stage (over the stress 
period) is computed at the gaging stations on the Little Spokane River at Dartford and near Dartford from daily recorded values. Because no gaging stations are located on the Little Spokane River downstream of the gaging station near Dartford, the stage at the mouth of the river (where the river joins the Spokane River) is estimated from the Nine Mile Falls USGS 7.5-minute topographic quadrangle to be 1,544 ft. For each river reach between the gaging stations at Dartford and near Dartford, the stage is estimated by assuming a uniform gradient in river level between the two gaging stations. A similar procedure is used to estimate the stage of a river reach between the gaging station near Dartford and the mouth of the river.

For each reach of the Little Spokane River in the model, the altitude of the bottom of the riverbed is assumed to be 10 $\mathrm{ft}$ below the river stage. This assumption is inconsequential to the simulation because the simulated head in the cell underlying the river reach is always higher than the bottom of the riverbed. Therefore, $h_{a}$ in equation 6 is always the hydraulic head in the cell. A single riverbed conductance is assigned to all reaches of the Little Spokane River. This conductance value, denoted as C-LSR, is estimated by model calibration.

Because equation 6 also can be used to describe lakebed seepage, the River Package is used to simulate subsurface seepage from Lake Pend Oreille and Coeur d'Alene Lake. For this usage, the terms river and riverbed in the definitions of variables in equation 6 are replaced, respectively, by lake and lakebed. The River Package is implemented at model cells underlying the near-shore region of the lake. For each stress period, the lake stage is specified as the average of the daily recorded lake levels over the stress period. Based on lake bathymetry data, the altitude of the bottom of the lakebed in the near-shore region is set to 1,860 ft for Lake Pend Oreille and 2,090 ft for Coeur d'Alene Lake. As in the case of the Little Spokane River, a single lakebed conductance is assigned to each lake. These two conductance values, denoted as C-PO for Lake Pend Oreille and C-CDA for Coeur d'Alene Lake, are estimated by model calibration.

\section{Streamflow-Routing Package}

The Streamflow-Routing Package (Prudic and others, 2004) is used to simulate the interaction between the Spokane River and the SVRP aquifer. In the Streamflow Routing Package, equations used to compute flow between the stream and the aquifer were the same as equations 6 and 7 in the River Package. However, the Streamflow-Routing Package is more powerful than the River Package because it provides various methods for routing water through a stream network.

The Streamflow-Routing Package requires data on stream-channel geometry. In the SVRP aquifer model, the channel of the Spokane River is approximated as having a rectangular cross section. Channel width and the altitude of the top of the streambed are estimated at 16 control points along the river from field measurements and data from previous studies (Seitz and Jones, 1981; Annear and others, 2001) and then linearly interpolated between control points. The thickness of the streambed sediments $(\mathrm{m})$ is assumed to be $1 \mathrm{ft}$. This assumption is not critical to the simulation because the streambed conductance depends on $\mathrm{K}_{v} / \mathrm{m}$, where $K_{v}$ is the vertical hydraulic conductivity of the streambed sediments. Thus, the actual variation in $\mathrm{m}$ can be included in the variability of $\mathrm{K}_{\mathrm{v}}$.

To represent $K_{v}$ of the streambed sediment, the Spokane River in the model area is divided into 11 sections (fig. 35). Within each section, $K_{v}$ is assumed to be uniform. Selection of the 11 river sections is based partially on factors that might affect $K_{v}$. For example, the character of the streambed sediment in a free-flowing part of the river might be different from the character of the streambed sediment where the river is a reservoir behind a dam. In addition, Caldwell and Bowers (2003) noted that the transport of fine-grained material with the leaking water from the Spokane River might decrease $K_{v}$ of the streambed sediments along a losing section of the river. The $K_{v}$ values of the 11 river sections are denoted by KVSR-1 through KVSR-11 and are estimated by model calibration.

Although the Streamflow-Routing Package is capable of simulating stream depth as a function of stream discharge using either Manning's equation or a rating curve, this capability is not used in the SVRP aquifer model because of the presence of dams, spillways, and reservoirs on the Spokane River. Instead, for every time step, stream stage is specified for every stream reach in the model. In this usage, the Streamflow-Routing Package functions in a manner similar to the River Package with the added capability of calculating a stream water budget for each stream reach.

Data used to determine stream stages include: (1) stage measurements at the four gaging stations on the Spokane River, (2) stage measurements for 1999 and 2000 for seven bridges across the Spokane River (Reanette Boese, Spokane County Utilities, written commun., 2006), and (3) levels of Coeur d'Alene Lake, Long Lake, and Nine Mile Reservoir. The altitude of Upriver Reservoir is assumed to be constant at 1,914 ft. The given data provide stream stages at 15 control points along the Spokane River. Between control points, stream stage is estimated by linear interpolation. If the stage data at a control point do not span the entire simulation period (1990-2005), a mathematical relation is developed between the available stage measurements at the control point and the corresponding stage at the gaging station near Post Falls (which has stage data for the entire simulation period). The relation between the stage at the Sullivan Road Bridge (where stage data are available for 1999 and 2000) and the stage at the gaging station near Post Falls is shown in figure 36. The equation shown in figure 36 is used to estimate the stage at Sullivan Road Bridge for periods with no stage data. 

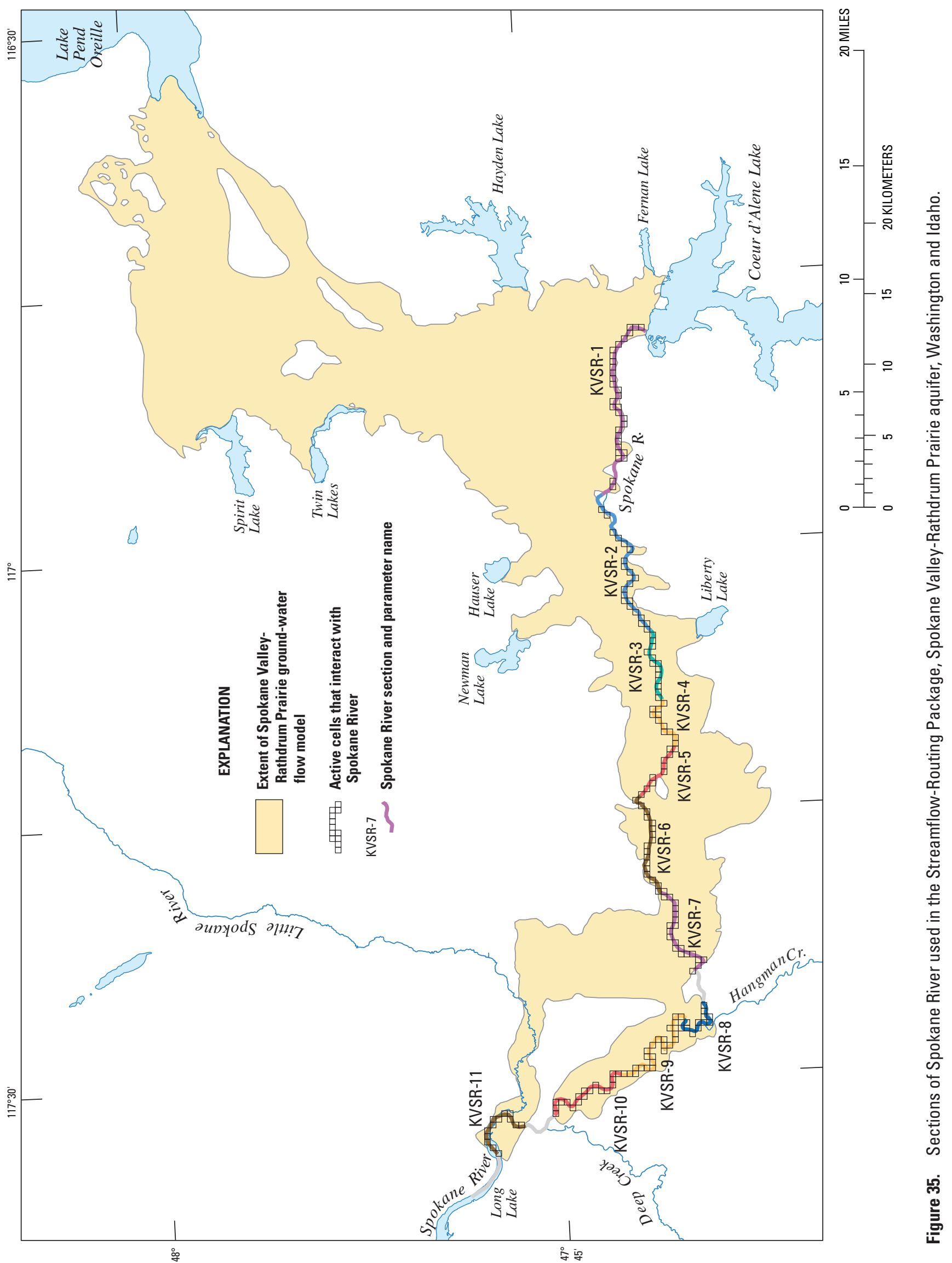


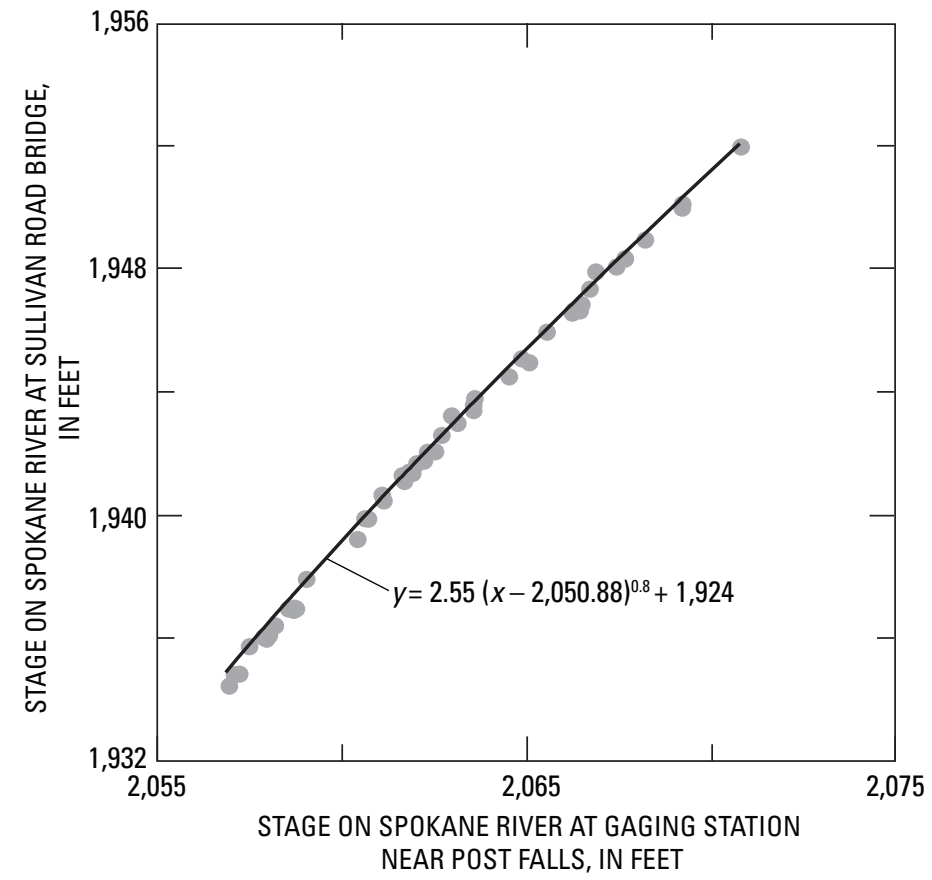

Figure 36. Relation between stage on the Spokane River at Sullivan Road Bridge (y) and stage at the gaging station near Post Falls (x), Spokane ValleyRathdrum Prairie aquifer, Washington and Idaho.

\section{General-Head Boundary Package}

The General-Head Boundary Package is used to simulate ground-water outflow from the lower unit at the west end of the Little Spokane River Arm. Available field data indicate that the lower unit extends beyond the model boundary, and ground water flows in the unit for an unknown distance before eventually discharging into Long Lake. The General-Head Boundary Package is used as an approximate representation of this conceptualization and is applied to four active cells at the west edge of model layer 3 (fig. 33). Ground-water outflow from each cell is computed as

$$
Q_{b}=C_{b}\left(h_{b}-h_{a}\right),
$$

For each stress period, $h_{b}$ is the average of the daily recorded levels of Long Lake over the stress period. A single boundary conductance, denoted as C-OUT, is assigned to all four cells, and the conductance is estimated by model calibration.

\section{Hydraulic Conductivity}

To represent the spatial distribution of $K_{h}$ in the SVRP aquifer, active cells in model layer 1 are grouped into 22 zones, denoted by HK1-1 through HK1-22, as shown in figure 37 . Within each zone, $\mathrm{K}_{\mathrm{h}}$ is uniform. Zones HK1-1 through HK1-11 represent the central part of the aquifer in Rathdrum Prairie, Spokane Valley, and the upper unit in Hillyard Trough and the Little Spokane River Arm. Zones HK1-12 and HK1-13 represent Trinity Trough and Western Arm, respectively. Zones HK1-14 and HK1-15 represent the areas in the vicinity of Hayden and Coeur d'Alene. Zones HK1-16 through HK1-22 represent side valleys and regions of shallow bedrock along the aquifer margins. Zone HK1-22 is included as a separate zone to represent a small side valley north of Coeur d'Alene. This arrangement provides greater flexibility during model calibration to simulate water levels in well 140, which is located in the side valley. The $K_{h}$ values for zones HK1-1 through HK1-22 are estimated by model calibration. For all active cells in model layer $1, K_{v}$ is set to $3,000 \mathrm{ft} / \mathrm{d}$. This $K_{v}$ value is intended to allow water to flow freely from model layer 1 into model layer 3 in the region south of the clay layer in Hillyard Trough.

Active cells in model layer 2 are grouped into two zones as indicated in figure 38. One zone represents the clay layer in Hillyard Trough and the Little Spokane River Arm. $K_{h}$ and $K_{v}$ values of these cells are set to $10^{-8} \mathrm{ft} / \mathrm{d}$. The other zone provides hydraulic connection between model layers 1 and 3 in the region south of the clay layer. These are the $1-\mathrm{ft}$ thick cells shown along section B-C in figure $34 . K_{h}$ and $K_{v}$ values of these cells are set to 3,000 ft/d.

Active cells in model layer 3 are grouped into two zones as shown in figure 39. Zone HK3-1 consists of cells in Hillyard Trough. Zone HK3-2 consists of cells in the Little Spokane River Arm. $K_{h}$ values of both zones are estimated by model calibration. As in the case of model layer 1, all active cells in model layer 3 are assigned a $K_{v}$ value of 3,000 ft/d to establish a direct hydraulic connection between model layers 1 and 3 in the region south of the clay layer in Hillyard Trough.

where

$C_{b} \quad$ is the boundary conductance,

$h_{b} \quad$ is the water level in Long Lake, and

$h_{a} \quad$ is the hydraulic head in the cell. 


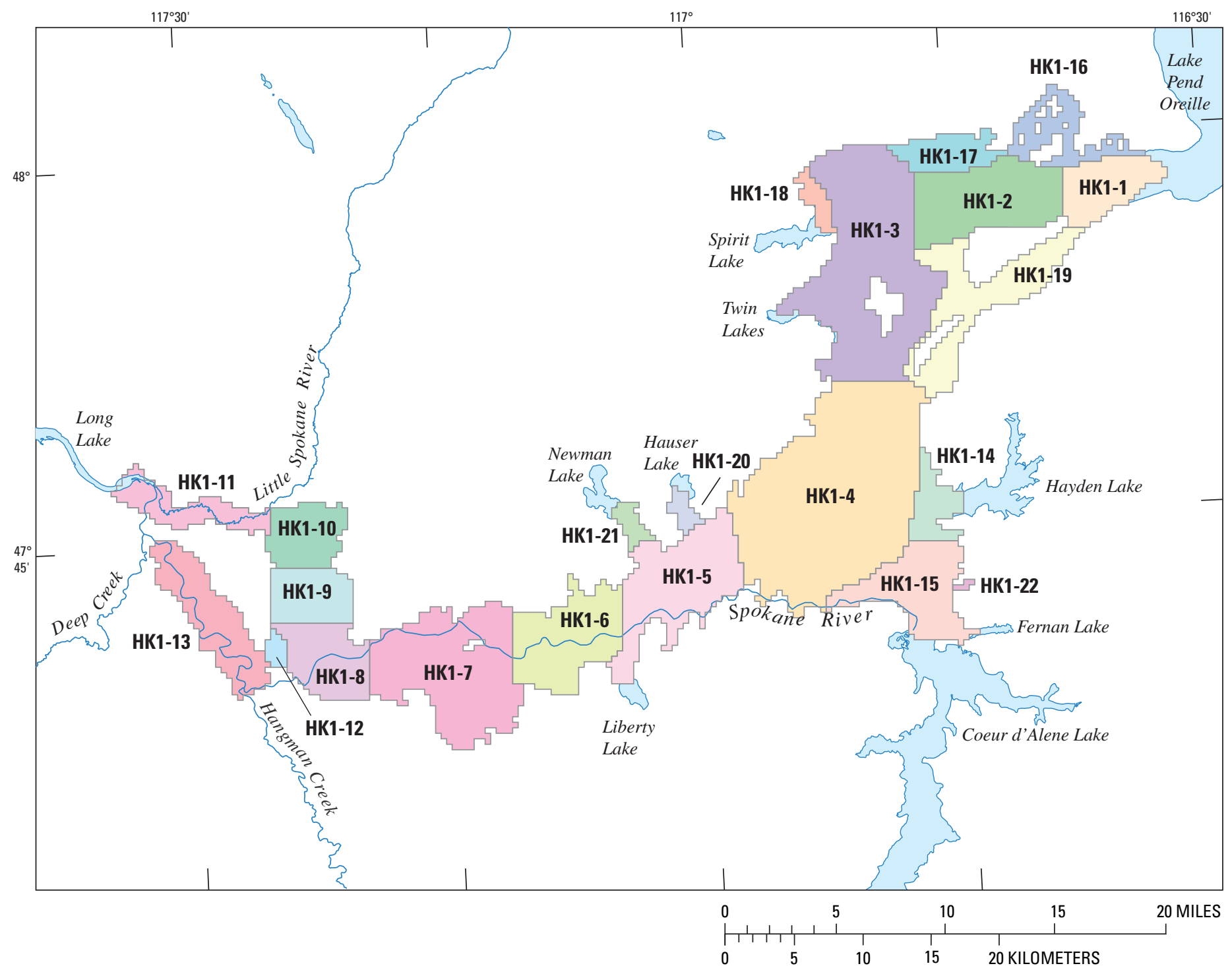

Figure 37. Horizontal hydraulic conductivity zones in model layer 1, Spokane Valley-Rathdrum Prairie aquifer, Washington and Idaho. 


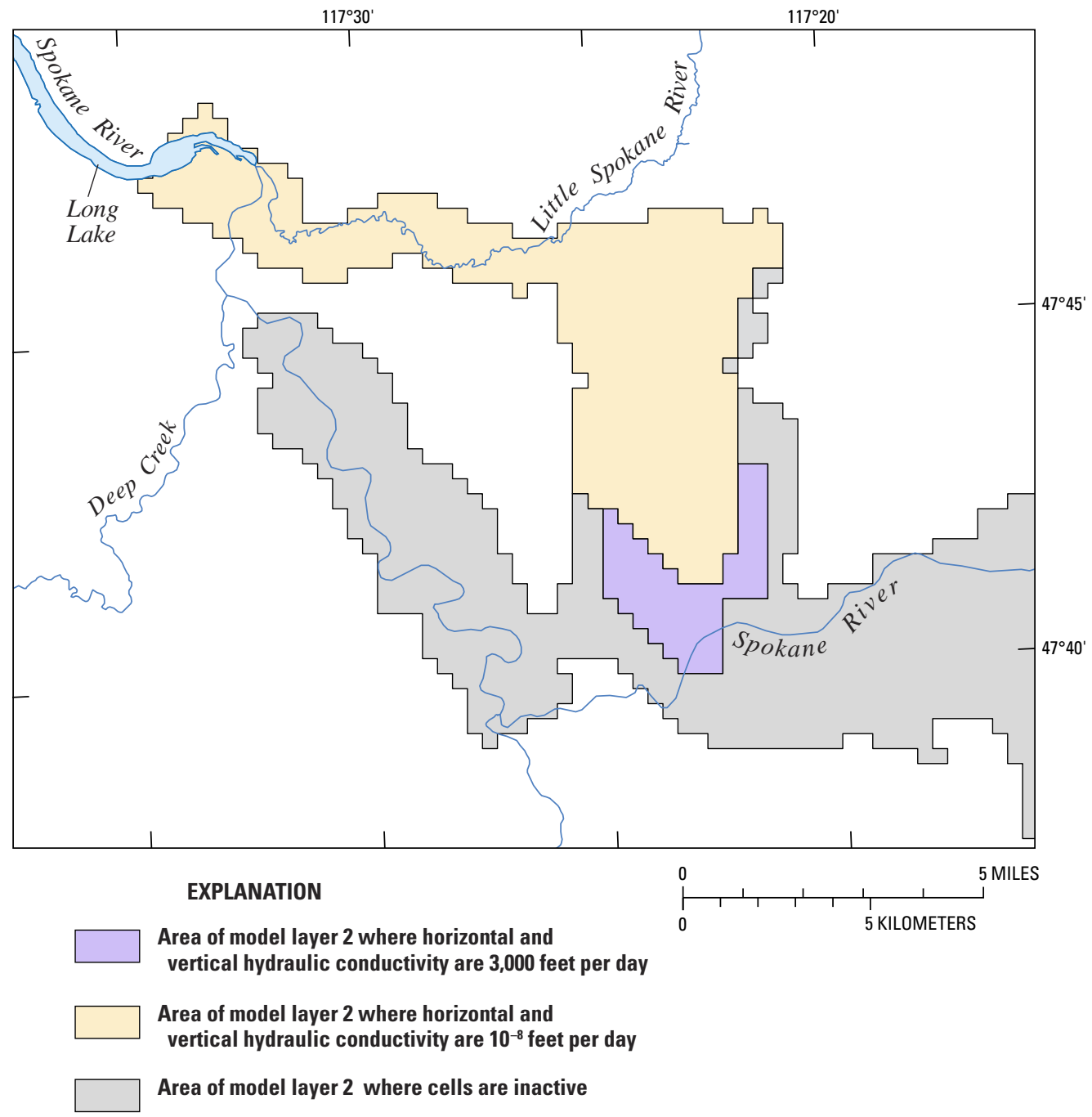

Figure 38. Hydraulic conductivity zones in model layer 2, Spokane Valley-Rathdrum Prairie aquifer, Washington and Idaho. 


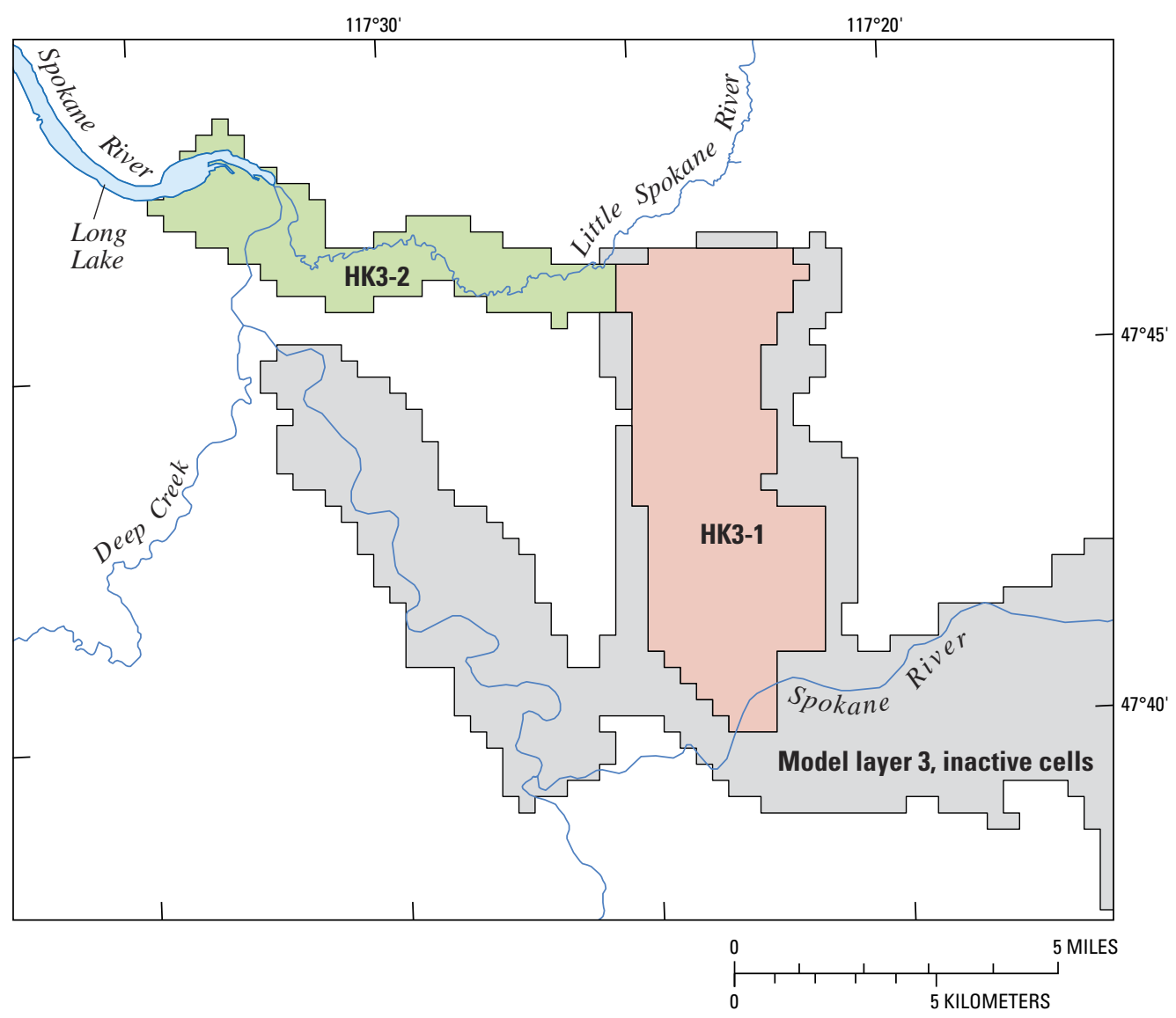

Figure 39. Horizontal hydraulic conductivity zones in model layer 3, Spokane Valley-Rathdrum Prairie aquifer, Washington and Idaho.

\section{Specific Yield}

The spatial distribution of $S_{Y}$ is represented by three zones as shown in figure 40. Because $S_{Y}$ values are expected to fall within a relatively limited range $(0.1-0.3)$, fewer zones are used to represent the spatial distribution of $S_{Y}$ than to represent the spatial distribution of $K_{n}$. Zone SY-1 represents, approximately, that part of the SVRP aquifer where water-level fluctuations are controlled primarily by recharge from precipitation. By contrast, zone SY-2 represents, approximately, that part of the aquifer where water-level fluctuations are controlled primarily by the Spokane River. Zone SY-3 represents regions of shallow bedrock along the margins of Rathdrum Prairie where water-level fluctuations are controlled by both recharge from precipitation and inflows from tributary basins and adjacent uplands. The three $S_{Y}$ values are estimated by model calibration. 


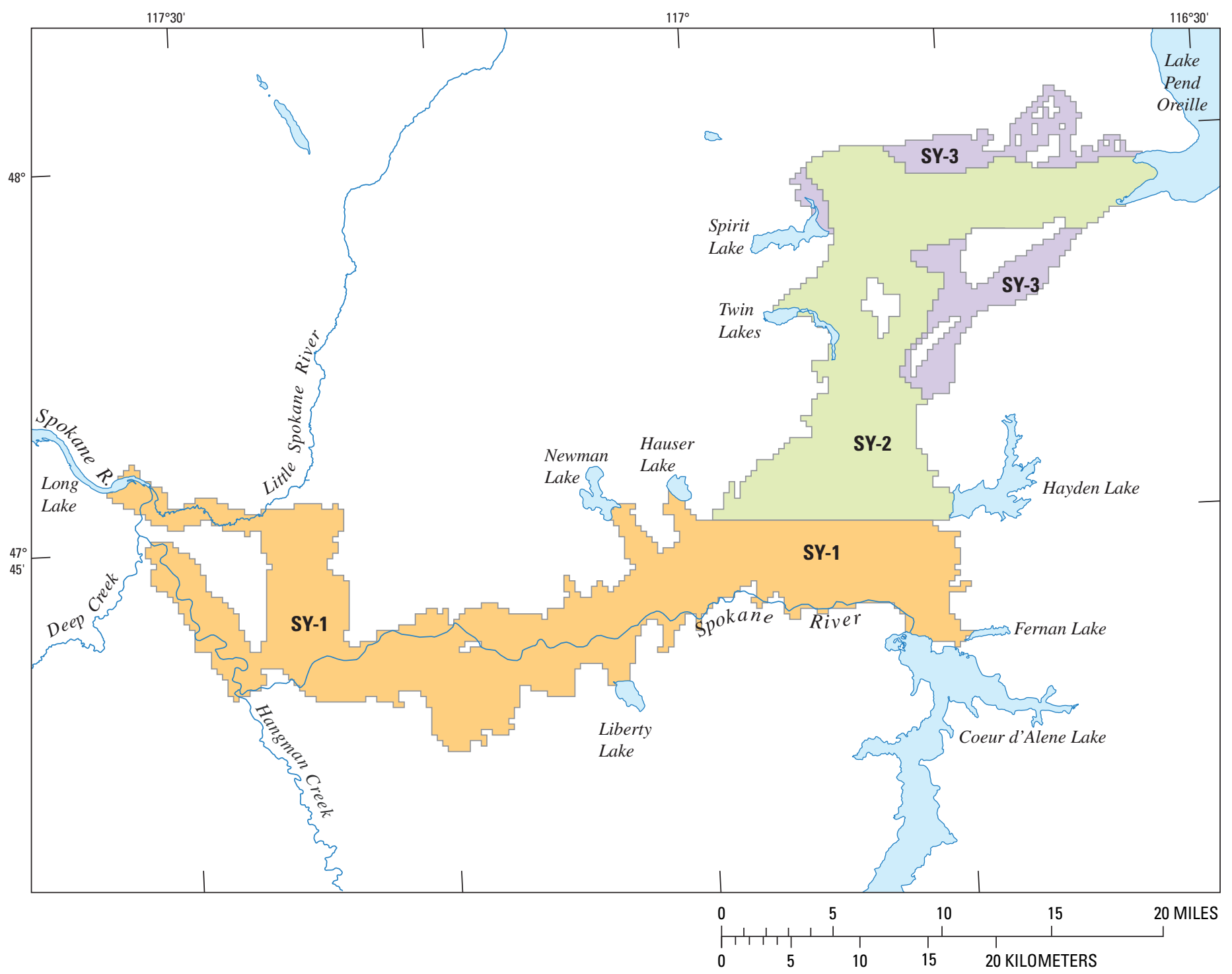

Figure 40. Specific yield zones, Spokane Valley-Rathdrum Prairie aquifer, Washington and Idaho. 


\section{Model Calibration}

Model calibration is the adjustment of model parameters (such as hydraulic conductivity and specific yield) so that the differences between simulated and measured quantities (such as water levels and flows) are minimized with respect to an objection function. This section of the report describes the nonlinear least-squares regression method used for calibration, the calibration data, and the calibration results. The calibration is assessed by examining how well the simulated quantities fit the measured quantities. Model assumptions are examined by comparing the calibrated model with several alternative models.

\section{Nonlinear Least-Squares Regression Method}

The parameter estimation program PEST version 10 (Doherty, 2004) is used to calibrate the SVRP aquifer model. PEST implements a nonlinear least-squares regression method to estimate model parameters by minimizing the sum of squared weighted residuals:

$$
\Phi=\sum_{i=1}^{N}\left(w_{i} r_{i}\right)^{2},
$$

where

$$
\begin{aligned}
& N \quad \text { is the number of measurements, } \\
& w_{i} \quad \text { is the weight for the } i^{\text {th }} \text { measured quantity, } \\
& \text { and } \\
& r_{i} \quad \text { is the } i^{\text {th }} \text { residual, defined as the } i^{\text {th }} \\
& \text { measured quantity minus the } \\
& \text { corresponding } i^{\text {th }} \text { simulated quantity. }
\end{aligned}
$$

The sum of squared weighted residuals, $\Phi$, also is known as the objective function. PEST uses the Gauss-MarquardtLevenberg method to minimize $\Phi$. Details of this method are given in the PEST user's manual (Doherty, 2004).

The weight, $w_{i}$, reflects the importance of the $i^{\text {th }}$ measured quantity on the regression. A measurement with a large $w_{i}$ asserts a large influence on the regression and, therefore, the estimated parameter values. Conversely, a measurement with a small $w_{i}$ asserts a small influence on the regression and estimated parameter values. Note that the notation for $w_{\text {f }}$ follows the convention used in the PEST manual. Other authors (for example, Hill, 1998) express equation 9 as

$$
\Phi=\sum_{i=1}^{N} \omega_{i} r_{i}^{2},
$$

and define $\omega_{i}$ as the weight. Therefore, $w_{i}$ as used in this report is equivalent to the square root of $\omega_{i}$ in equation 10.

\section{Calibration Data}

The SVRP aquifer model is calibrated using both waterlevel and flow measurements. Water-level measurements include:

1. Synoptic water-level measurements for 268 wells during September 2004,

2. Monthly water-level measurements for 55 monitoring wells from the summer of 2004 through September 2005,

3. Water-level measurements by Caldwell and Bowers (2003) for 11 wells in the vicinity of the Spokane River during 2000 and 2001, and

4. Historical water-level data for four wells in the monitoring network (wells 92, 209, 236, and 251) from October 1995 to September 2005.

A total of 1,573 water-level measurements are used in the model calibration. Water-level measurements for several wells are excluded as calibration data. A well is excluded if it meets one of the following criteria: (a) the well is completed in bedrock or in both bedrock and in aquifer sediments, (b) the well encounters the narrow ground-water mound beneath the losing segment of the Spokane River upstream of the gaging station at Greenacres, and (c) the well is located along the aquifer boundary where water levels differ by more than several tens of feet from those of nearby wells.

Flow measurements consist of streamflow gains and losses along segments of the Spokane and Little Spokane Rivers. Flow measurements include:

1. Monthly average streamflow gains and losses from October 1995 to July 1999 on the segment of the Spokane River from the gaging stations near Post Falls to at Spokane,

2. Monthly average streamflow gains and losses from August 1999 to September 2005 on the segment of the Spokane River from the gaging stations near Post Falls to at Greenacres,

3. Monthly average streamflow gains and losses from August 1999 to September 2005 on the segment of the Spokane River from the gaging stations at Greenacres to at Spokane,

4. Monthly average streamflow gains from October 1997 to September 2005 on the segment of the Little Spokane River from the gaging stations at Dartford to near Dartford,

5. Synoptic streamflow gains and losses on the Spokane and Little Spokane Rivers during the seepage run during September 13-16, 2004, and 
6. Synoptic streamflow gains and losses on the Spokane and Little Spokane Rivers during the seepage run during August 26-31, 2005.

A total of 313 flow measurements are used in the model calibration.

\section{Weights for Measured Quantities}

A standard approach to determining the weight for a measured quantity is to calculate $w_{i}$ as the inverse of the standard deviation of the error associated with the $i^{\text {th }}$ measured quantity (Hill, 1998). To apply this approach, the following sources of error are evaluated for water-level measurements:

1. Error in the altitude of land surface datum at the well site. For all wells used in this study, the land surface datum errors are given in the column under the heading "Accuracy of land-surface altitude" in table 1 of the water-level map by Campbell (2005). These errors range from 0.01 to $20 \mathrm{ft}$. The altitudes of several well sites have been re-surveyed since the publication of the water-level map.

2. Error in the measurement method. For the September 2004 synoptic water-level data listed in table 1 of the water-level map by Campbell (2005), the measurement method is given in the column under the heading "Method of water-level measurement." Six measurement method codes are listed: A (airline), C (calibrated airline), G (pressure gage), S (steel tape), T (electric tape), and V (calibrated electric tape). For the weight calculation, the error is assumed to be $5 \mathrm{ft}$ for A, C, and G, and $0.02 \mathrm{ft}$ for $\mathrm{S}, \mathrm{T}$, and V. For all other water-level measurements used in the model calibration, the measurement method is assumed to be $\mathrm{S}, \mathrm{T}$, or $\mathrm{V}$, and the error is assumed to be $0.02 \mathrm{ft}$.

3. Error from local disturbance, such as pumping. This error is inferred from a water-level status code that is recorded with each water-level measurement. If the code is $\mathrm{P}$ (the well is being pumped at the time of measurement), the error is assumed to be $10 \mathrm{ft}$. If the code is R (the well was recently pumped prior to the time of measurement), the error is assumed to be $2 \mathrm{ft}$. If the code is $\mathrm{S}$ (a nearby well is being pumped at the time of measurement) or $\mathrm{T}$ (a nearby well was recently pumped prior to the time of measurement), the error is assumed to be $1 \mathrm{ft}$. If no code is recorded, the error is assumed to be zero.

Following Hill's (1998, p. 46) suggestion, each of the above error values is interpreted as a 95-percent confidence interval. For example, a land-surface datum error of $10 \mathrm{ft}$ is interpreted to mean that the probability is 95 percent that the actual land-surface datum is within $\pm 10 \mathrm{ft}$ of the measured datum. If the error is assumed to be a normally distributed random variable, then a 10 -ft error is equal to 1.96 times the standard deviation. Therefore, the standard deviation is $5.1 \mathrm{ft}$. To account for multiple sources of errors, the variance (square of standard deviation) for each error source is computed, the variances are summed, and the square root of the sum is calculated. This gives the standard deviation of the total error. The weight then is computed as the inverse of this standard deviation.

A similar procedure (Hill, 1998, p. 46-47) is used to determine the weights of the flow measurements (streamflow gains and losses). Because the streamflow gain or loss on a river segment is determined from the difference between streamflows at the upstream and downstream ends of the river segment, the variances of the errors of the two streamflow values are summed. Based on the study by Sauer and Meyer (1992), the error of a streamflow measurement is estimated to be 5 percent of the measured value. To illustrate the weight calculation, suppose the streamflow at the upstream gaging station is $1,000 \mathrm{ft}^{3} / \mathrm{s}$ and the streamflow at the downstream gaging station is $800 \mathrm{ft}^{3} / \mathrm{s}$, giving a streamflow loss of 200 $\mathrm{ft}^{3} / \mathrm{s}$. For the streamflow at the upstream gaging station, the error is $50 \mathrm{ft}^{3} / \mathrm{s}$. Interpreting this error to equal 1.96 times the standard deviation gives a standard deviation of $25.5 \mathrm{ft}^{3} / \mathrm{s}$, or a variance of $651\left(\mathrm{ft}^{3} / \mathrm{s}\right)^{2}$. By the same reasoning, the error of the streamflow at the downstream gaging station is $40 \mathrm{ft}^{3} / \mathrm{s}$, giving a standard deviation of $20.4 \mathrm{ft}^{3} / \mathrm{s}$ and a variance of $416\left(\mathrm{ft}^{3} / \mathrm{s}\right)^{2}$. The variance of the error of the streamflow loss $\left(200 \mathrm{ft}^{3} / \mathrm{s}\right)$ is the sum of the variances of the upstream and downstream streamflows, or $1,067\left(\mathrm{ft}^{3} / \mathrm{s}\right)^{2}$. The standard deviation is 32.7 $\mathrm{ft}^{3} / \mathrm{s}$, and the weight is the inverse of the standard deviation.

Initial calibration runs using weights determined by the previously described procedure indicated that the sum of squares of weighted residuals is heavily dominated by the water-level measurements, and the fit to flow measurements is poor. This results from the fact that (1) the number of water-level measurements is five times the number of flow measurements, and (2) relative errors in water-level measurements generally are much smaller than relative errors in flow measurements. To create a more even balance between the weighted water-level residuals and the weighted flow residuals, the weights for water-level measurements are reduced by adding $5 \mathrm{ft}$ to the standard deviations of the water-level errors. This adjustment improves the fit to flow measurements without substantially degrading the fit to waterlevel measurements. 


\section{Estimated Parameters}

The calibration set-up as previously described involves 42 parameters. These parameters are listed in the first column of table 8. During the initial calibration phase, it was determined that calibration data were insensitive to HK1-21 (the horizontal hydraulic conductivity of the side valley in which Newman Lake is located) and KVSR-11 (the vertical hydraulic conductivity of the streambed sediments in the segment of the Spokane River in the Little Spokane River Arm). In addition, initial calibration runs yielded relatively high values of $\mathrm{C}$ OUT (the boundary conductance for outflow from the lower unit to Long Lake), but the estimated C-OUT was nonunique and varied from one calibration run to another depending on starting parameter values. In addition, the estimated value of HK3-2 (horizontal hydraulic conductivity of the lower unit in the Little Spokane Arm) was unreasonably high. Therefore, the four previously mentioned parameters are not estimated by calibration but are assigned as follows. HK1-21 is set to 150 $\mathrm{ft} / \mathrm{d}$. This $K_{h}$ value results in a simulated water level of about $2,100 \mathrm{ft}$ in the vicinity of Newman Lake. This water level is about $30 \mathrm{ft}$ below the level of Newman Lake. KVSR-11 is set to $0.1 \mathrm{ft} / \mathrm{d}$. This $K_{v}$ value limits the interaction between the aquifer and the segment of the Spokane River in the Little Spokane River Arm. The limited interaction is reasonable because most of the ground-water discharge in the Little Spokane River Arm would enter the Little Spokane River. C-OUT is set to a relatively high value of $10^{6} \mathrm{ft}^{2} / \mathrm{d}$. Increasing or decreasing this value by one order of magnitude has little or no effect on the simulation results. However, setting a high value for C-OUT is nearly equivalent to setting the head at the outflow boundary close to the level of Long Lake. HK3-2 is set to $2,000 \mathrm{ft} / \mathrm{d}$. This value based on $\mathrm{K}_{\mathrm{h}}$ values estimated for the Hillyard Trough area (see fig. 6).

The PEST program requires specifying an acceptable interval for each estimated parameter. The lower and upper limits defining this interval are given in the third and fourth columns of table 8 . For hydraulic conductivity and conductance, the acceptable interval is set fairly wide, with the expectation that the estimated value would fall within the acceptable interval. For specific yield, the acceptable interval is set from 0.1 to 0.3 . PEST always yields an estimated value that is within the parameter's acceptable interval (inclusive of the upper and lower limits).
Estimated values obtained from the calibration are given in the fifth column of table 8 . A value in bold indicates that the estimated value is at either the upper or lower limit of the acceptable interval. In the central part of the aquifer in Rathdrum Prairie and in Spokane Valley, estimated $K_{h}$ values ranged from 6,170 to 22,100 ft/d. In Hillyard Trough, the Little Spokane River Arm, and Western Arm, estimated $\mathrm{K}_{\mathrm{h}}$ values ranged from 1,980 to 3,110 ft/d. In the Coeur d'Alene area, the estimated $K_{h}$ value is $1,290 \mathrm{ft} / \mathrm{d}$. For side valleys and regions of shallow bedrock along the margins of the aquifer, estimated $K_{h}$ values ranged from 5 to $140 \mathrm{ft} / \mathrm{d}$. These estimated $K_{h}$ values generally are consistent with $K_{h}$ values estimated in previous studies (see the discussion in the section, "Hydraulic Properties.").

Estimated $S_{Y}$ values are 0.1 for SY-1, 0.19 for SY-2, and 0.21 for SY-3. The estimated SY-1 value is at the lower limit of the acceptable range. The implication of this calibration result is explored using alternative model $\mathrm{C}$ in the section, "Alternative Models."

Estimated $K_{v}$ values of streambed sediments indicate that these parameters are related to gaining and losing segments of the Spokane River. Along losing segments of the Spokane River, estimated $K_{v}$ values of streambed sediments are less than $1 \mathrm{ft} / \mathrm{d}$ (parameters KVSR-1 to KVSR-4, KVSR-6, and KVSR-8). Along gaining segments of the Spokane River, estimated $K_{v}$ values of streambed sediments are greater than 1 ft/d (parameters KVSR-5, KVSR-7, KVSR-9, and KVSR-10). These results support the suggestion by Caldwell and Bowers (2003) that the transport of fine-grained material with the leaking water from the Spokane River might decrease $K_{v}$ of the streambed sediments along a losing segment of the river.

The sixth and seventh columns of table 8 give the linear, 95-percent confidence interval for the estimated parameter values. These confidence intervals should be interpreted with caution. The confidence intervals are approximate and are computed under the assumption that the model is linear with respect to the parameters in the vicinity of the estimated values. If this linearity assumption is not valid, then the confidence intervals are inaccurate. 
Table 8. Model parameters, acceptable intervals, estimated values, and 95-percent confidence intervals.

[Value in italic indicates parameter is specified and not estimated; value in bold indicates that estimated value is at either upper or lower limit of acceptable interval. Abbreviations: $\mathrm{ft} / \mathrm{d}$, foot per day; --, dimensionless; $\mathrm{ft}$ /d, foot squared per day; n.a., not assigned; n.c., not calculated]

\begin{tabular}{|c|c|c|c|c|c|c|}
\hline \multirow{2}{*}{ Parameter } & \multirow{2}{*}{ Units } & \multicolumn{2}{|c|}{ Acceptable interval } & \multirow{2}{*}{ Estimated value } & \multicolumn{2}{|c|}{ 95-percent confidence interval } \\
\hline & & Lower limit & Upper limit & & Lower limit & Upper limit \\
\hline HK1-1 & $\mathrm{ft} / \mathrm{d}$ & 100 & 50,000 & 13,000 & 6,440 & 26,400 \\
\hline HK1-2 & $\mathrm{ft} / \mathrm{d}$ & 100 & 50,000 & 6,170 & 4,300 & 8,860 \\
\hline HK1-3 & $\mathrm{ft} / \mathrm{d}$ & 100 & 50,000 & 17,100 & 13,500 & 21,700 \\
\hline HK1-4 & $\mathrm{ft} / \mathrm{d}$ & 100 & 50,000 & 12,100 & 10,800 & 13,500 \\
\hline HK1-5 & $\mathrm{ft} / \mathrm{d}$ & 100 & 50,000 & 22,100 & 20,200 & 24,300 \\
\hline HK1-6 & $\mathrm{ft} / \mathrm{d}$ & 100 & 50,000 & 19,100 & 17,800 & 20,400 \\
\hline HK1-7 & $\mathrm{ft} / \mathrm{d}$ & 100 & 50,000 & 7,470 & 6,820 & 8,170 \\
\hline HK1-8 & $\mathrm{ft} / \mathrm{d}$ & 100 & 50,000 & 9,500 & 8,040 & 11,200 \\
\hline HK1-9 & $\mathrm{ft} / \mathrm{d}$ & 1 & 5,000 & 2,630 & 2,400 & 2,870 \\
\hline HK1-10 & $\mathrm{ft} / \mathrm{d}$ & 1 & 5,000 & 2,180 & 2,020 & 2,360 \\
\hline HK1-11 & $\mathrm{ft} / \mathrm{d}$ & 1 & 5,000 & 1,980 & 1,710 & 2,300 \\
\hline HK1-12 & $\mathrm{ft} / \mathrm{d}$ & 1 & 5,000 & 608 & 485 & 762 \\
\hline HK1-13 & $\mathrm{ft} / \mathrm{d}$ & 1 & 5,000 & 3,110 & 2,470 & 3,920 \\
\hline HK1-14 & $\mathrm{ft} / \mathrm{d}$ & 1 & 5,000 & 90 & 82 & 98 \\
\hline HK1-15 & $\mathrm{ft} / \mathrm{d}$ & 1 & 5,000 & 1,290 & 755 & 2,190 \\
\hline HK1-16 & $\mathrm{ft} / \mathrm{d}$ & 1 & 5,000 & 55 & 53 & 56 \\
\hline HK1-17 & $\mathrm{ft} / \mathrm{d}$ & 1 & 5,000 & 5 & 4 & 7 \\
\hline HK1-18 & $\mathrm{ft} / \mathrm{d}$ & 1 & 5,000 & 78 & 74 & 82 \\
\hline HK1-19 & $\mathrm{ft} / \mathrm{d}$ & 1 & 5,000 & 95 & 93 & 97 \\
\hline HK1-20 & $\mathrm{ft} / \mathrm{d}$ & 1 & 5,000 & 64 & 55 & 76 \\
\hline HK1-21 & $\mathrm{ft} / \mathrm{d}$ & n.a. & n.a. & 150 & n.c. & n.c. \\
\hline HK1-22 & $\mathrm{ft} / \mathrm{d}$ & 1 & 5,000 & 140 & 131 & 150 \\
\hline HK3-1 & $\mathrm{ft} / \mathrm{d}$ & 1 & 5,000 & 207 & 155 & 276 \\
\hline HK3-2 & $\mathrm{ft} / \mathrm{d}$ & n.a. & n.a. & 2,000 & n.c. & n.c. \\
\hline SY-1 & -- & .1 & .3 & .1 & .08 & .13 \\
\hline SY-2 & -- & .1 & .3 & .19 & .16 & .21 \\
\hline SY-3 & -- & .1 & .3 & .21 & .18 & .23 \\
\hline KVSR-1 & $\mathrm{ft} / \mathrm{d}$ & .01 & 10 & .054 & .047 & .062 \\
\hline KVSR-2 & $\mathrm{ft} / \mathrm{d}$ & .01 & 10 & .25 & .23 & .27 \\
\hline KVSR-3 & $\mathrm{ft} / \mathrm{d}$ & .01 & 10 & .27 & .24 & .29 \\
\hline KVSR-4 & $\mathrm{ft} / \mathrm{d}$ & .01 & 10 & .14 & .10 & .20 \\
\hline KVSR-5 & $\mathrm{ft} / \mathrm{d}$ & .01 & 10 & 9.4 & 7.3 & 12.2 \\
\hline KVSR-6 & $\mathrm{ft} / \mathrm{d}$ & .01 & 10 & .01 & .005 & 1.8 \\
\hline KVSR-7 & $\mathrm{ft} / \mathrm{d}$ & .01 & 10 & 10 & 5.6 & 18 \\
\hline KVSR-8 & $\mathrm{ft} / \mathrm{d}$ & .01 & 10 & .3 & .20 & .45 \\
\hline KVSR-9 & $\mathrm{ft} / \mathrm{d}$ & .01 & 10 & 10 & 1.70 & 59 \\
\hline KVSR-10 & $\mathrm{ft} / \mathrm{d}$ & .01 & 10 & 10 & .63 & 159 \\
\hline KVSR-11 & $\mathrm{ft} / \mathrm{d}$ & n.a. & n.a. & .1 & n.c. & n.c. \\
\hline C-LSR & $\mathrm{ft}^{2} / \mathrm{d}$ & $10^{-10}$ & $10^{10}$ & 40,600 & 36,100 & 45,700 \\
\hline C-PO & $\mathrm{ft}^{2} / \mathrm{d}$ & $10^{-10}$ & $10^{10}$ & 241,000 & 102,000 & 572,000 \\
\hline C-CDA & $\mathrm{ft}^{2} / \mathrm{d}$ & $10^{-10}$ & $10^{10}$ & 77,800 & 40,000 & 151,000 \\
\hline C-OUT & $\mathrm{ft}^{2} / \mathrm{d}$ & n.a. & n.a. & $10^{6}$ & n.c. & n.c. \\
\hline
\end{tabular}




\section{Assessment of Calibration}

The results of the calibration can be assessed by comparing simulated and measured quantities and by examining the weighted residuals. Simulated and measured water levels in selected wells in various parts of the SVRP aquifer are shown in figure 41. Except as noted, the same scale is used for all vertical axes for ease of comparison of waterlevel fluctuations in different wells.

For the upgradient end of the aquifer near Lake Pend Oreille, simulated and measured water levels in well 236 are in close agreement (fig. 41A). For northern Rathdrum Prairie, simulated and measured water levels in well 251 (fig. 41B) and well 249 (fig. 41C) are compared. In well 251, the simulated rise in water level during 1996 and 1997 is not as large as the measured rise. In both wells 249 and 251, the simulated fluctuations during 2004 and 2005 are somewhat larger in magnitude than the measured fluctuations. These discrepancies likely are due to two simplifying assumptions used in calculating recharge from precipitation: (1) use of a triangular network to linearly interpolate recharge from precipitation (fig. 7), and (2) use of a linear relation between depth of water table and transmission time for precipitation infiltration to reach water table (table 2).

For southern Rathdrum Prairie, simulated and measured water levels in well 225 (fig. 41D) and well 178 (fig. 41E) are compared. In both wells, the simulated water levels are close to the measured water levels, but the character of the simulated fluctuations during 2004-05 does not match the character of the measured fluctuations. The same discrepancy is shown in the simulated and measured water levels in well 143 (fig. 41F), which is near Coeur d'Alene Lake. These discrepancies indicate that the temporal distribution of recharge to southern Rathdrum Prairie (including the Coeur d'Alene area) might not be represented accurately in the model for 2004-05.

Simulated and measured water levels in well 246 near the east edge of Rathdrum Prairie and in well 140 in a side valley between Coeur d'Alene and Hayden are shown in figures 41G and $41 \mathrm{H}$, respectively. Note that the vertical axes in both figures span $120 \mathrm{ft}$. Although these wells have few long-term historical data for calibration, the simulation indicates that water levels along the margins of Rathdrum Prairie can rise and decline by substantial amounts.

Simulated and measured water levels in wells in various parts of Spokane Valley are shown in figures 41I to $41 \mathrm{M}$. Overall, the seasonal rise and decline of simulated water levels reproduce the measured water levels. However, simulated fluctuations on short time scales do not always match the measured fluctuations. For example, each year during September, the measured water level in well 92 (fig. 41K) rises in response to the rise in Spokane River stage as the gates at the Post Falls Dam are opened. However, the simulated water level during September does not always follow the rises in the measured water level. This discrepancy might be a consequence of assuming a rectangular cross-section for the channel of the Spokane River. Under this assumption, the streambed area through which seepage occurs is independent of river stage. In reality, under low-flow conditions typical of later summer, the river might occupy only a portion of the streambed. As the river stage rises in September, the river might occupy a larger area of streambed. Because the model does not simulate this increase in wetted streambed area, the simulated exchange between the aquifer and the Spokane River might be inaccurate during early autumn.

Simulated and measured water levels in well 6 in Trinity Trough are shown in figure 41N. The magnitude of the simulated water-level fluctuation is substantially smaller than the magnitude of the measured fluctuation. During 2004-05, the water level in well 6 rose and declined by about $15 \mathrm{ft}$. This is nearly double the magnitude of the fluctuations in other wells in Spokane Valley. Well 6 is located in an area of steep hydraulic gradient as ground water is channeled through Trinity Trough into Western Arm (fig. 22). The discrepancy between simulated and measured water levels in well 6 might indicate that a finer model grid (with smaller model cells) is needed to more accurately represent Trinity Trough.

Simulated and measured water levels in well 128 in Hillyard Trough and in well 107 in Western Arm are shown in figures 410 and $41 \mathrm{P}$, respectively. For both wells, the simulated water levels are in fairly good agreement with the measured water levels.

Simulated and measured water levels in the lower unit are shown in figures 410 and $41 \mathrm{R}$. Well 115 (fig. 41Q) is at the north end of Hillyard Trough. The drawdowns during 2004-05 are a result of pumping of a nearby production well. However, the simulated drawdowns were substantially larger than the measured drawdowns, indicating that the estimated value of KH3-1 might be too low. Well 99 (fig. 41R) is located on the west side of the Little Spokane River Arm. In this well, simulated water levels were about $15 \mathrm{ft}$ higher than the measured water levels. Considered together, the relatively poor fits to measured water levels in wells 115 and 99 indicate that the lower unit might not be represented accurately by the model.

Simulated water levels in model layer 1 during September 2004 are shown in figure 42. The contours of simulated water levels shown in figure 42 are in good agreement with the contours of measured water levels shown in figure 22. Simulated water levels in model layer 3 during September 2004 are shown in figure 43. Because water-level measurements are available for only two wells in the lower unit, too few data are available to construct a map of measured water levels in the lower unit. 

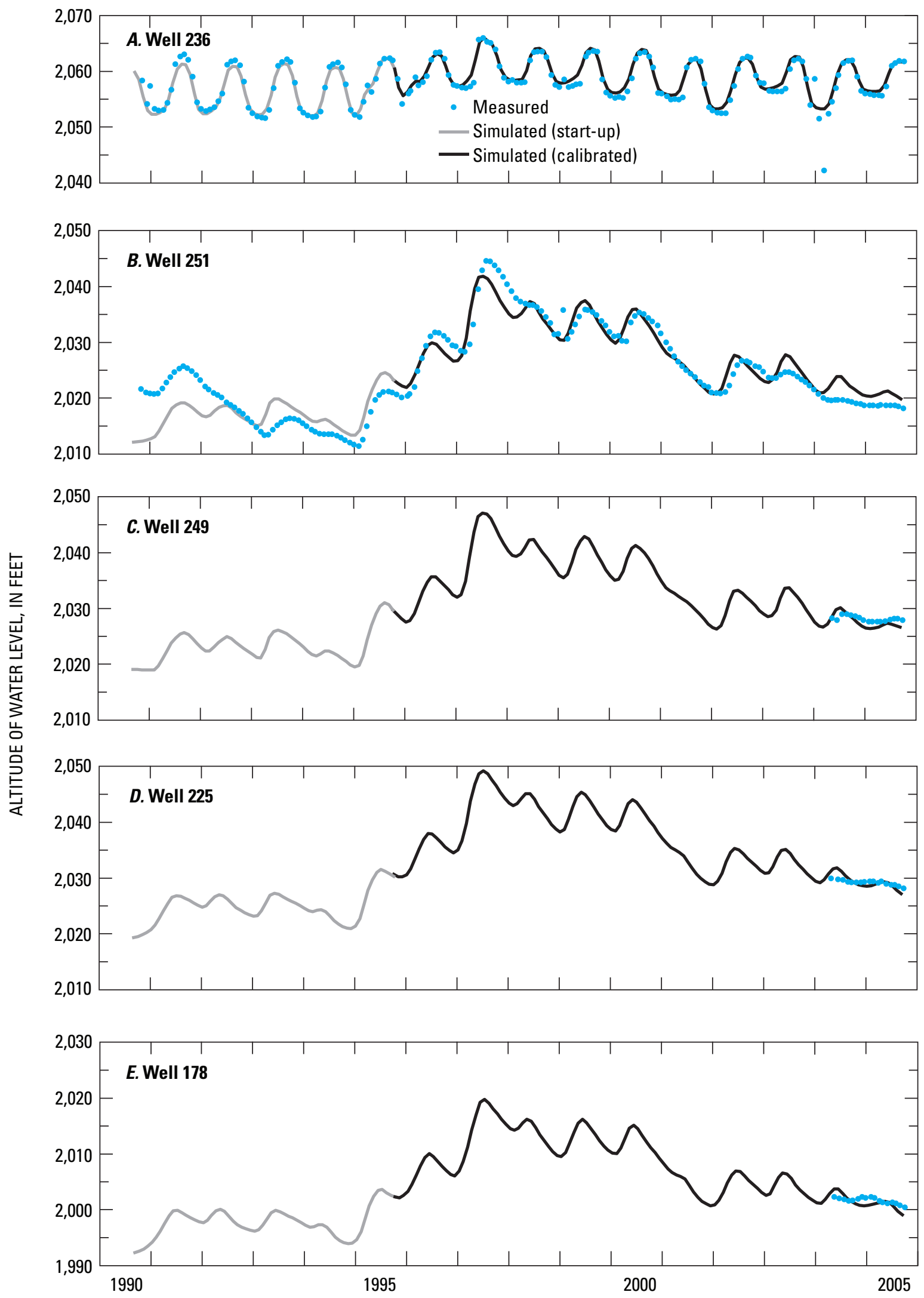

Figure 41. Simulated and measured water levels in selected wells in various parts of the SpokaneRathdrum Prairie aquifer, Washington and Idaho. 

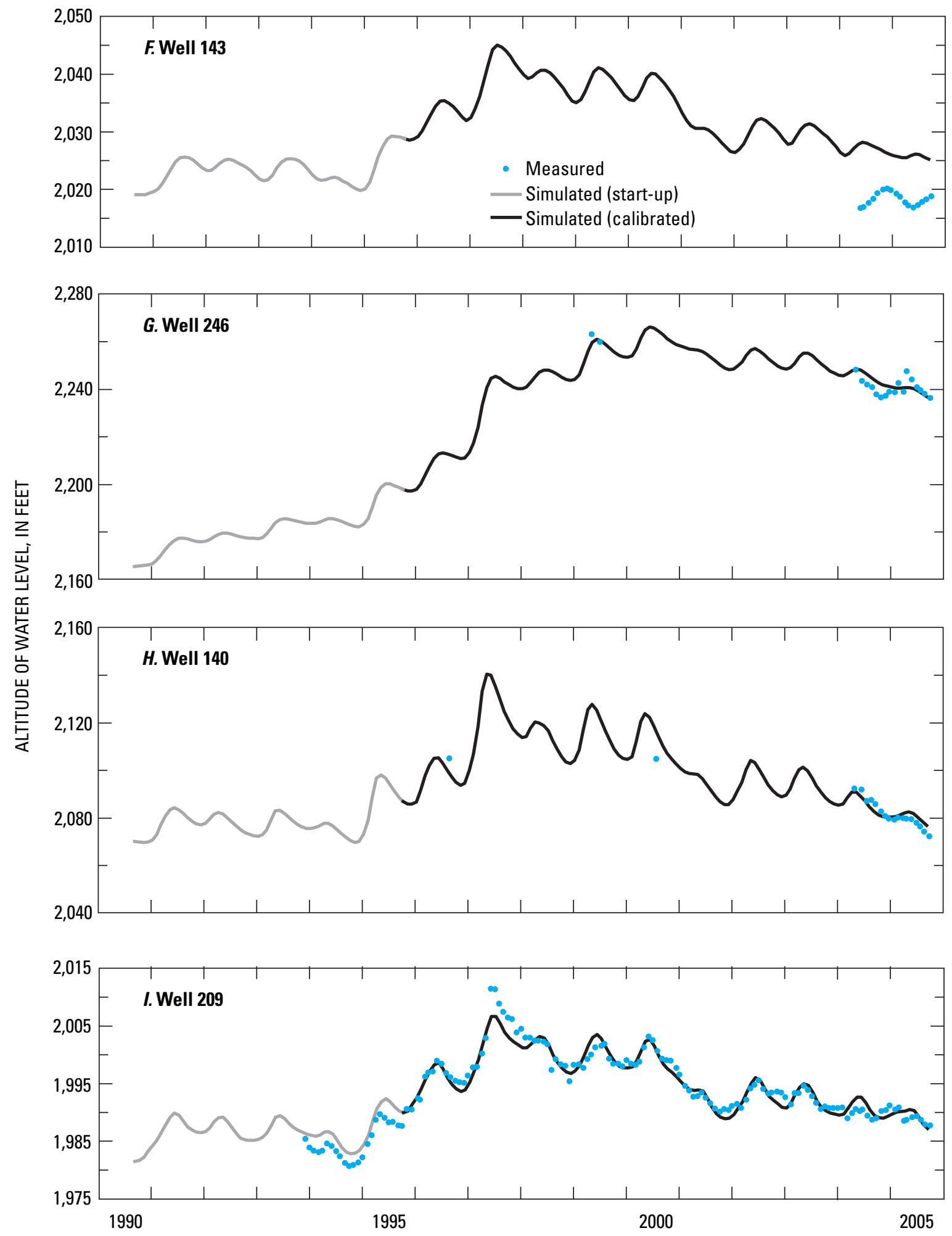

Figure 41.-Continued. 

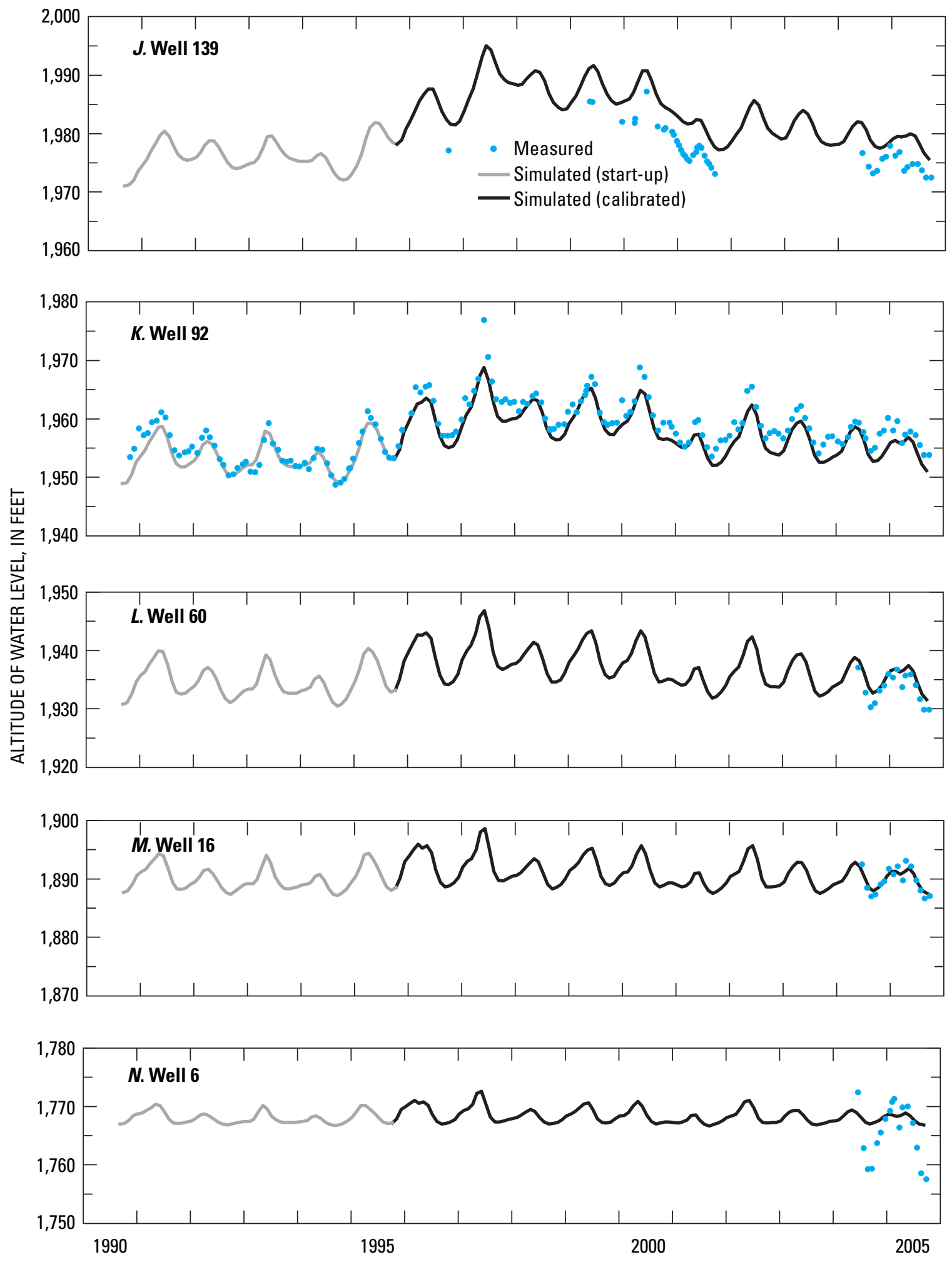

Figure 41.-Continued. 

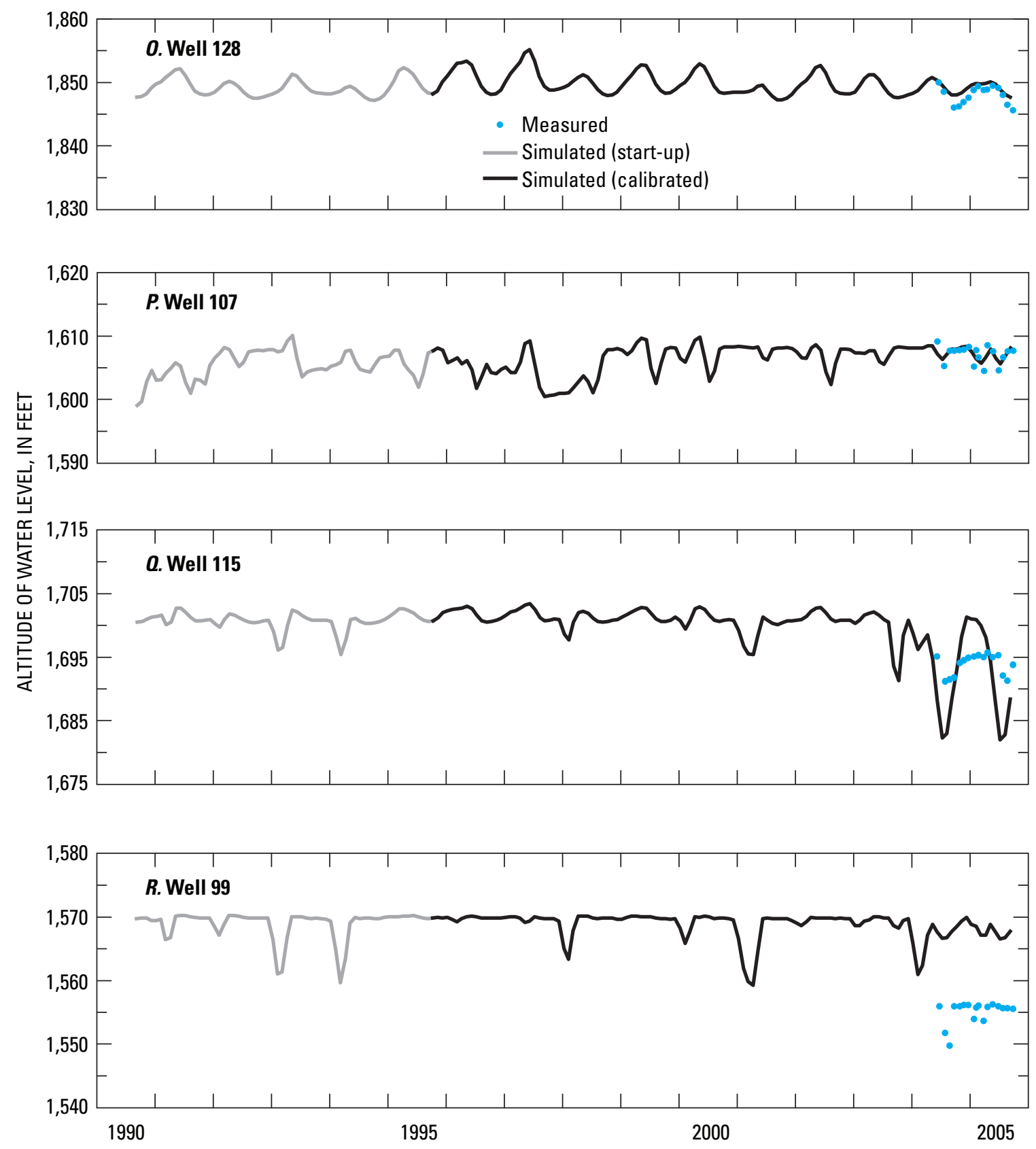

Figure 41.-Continued. 


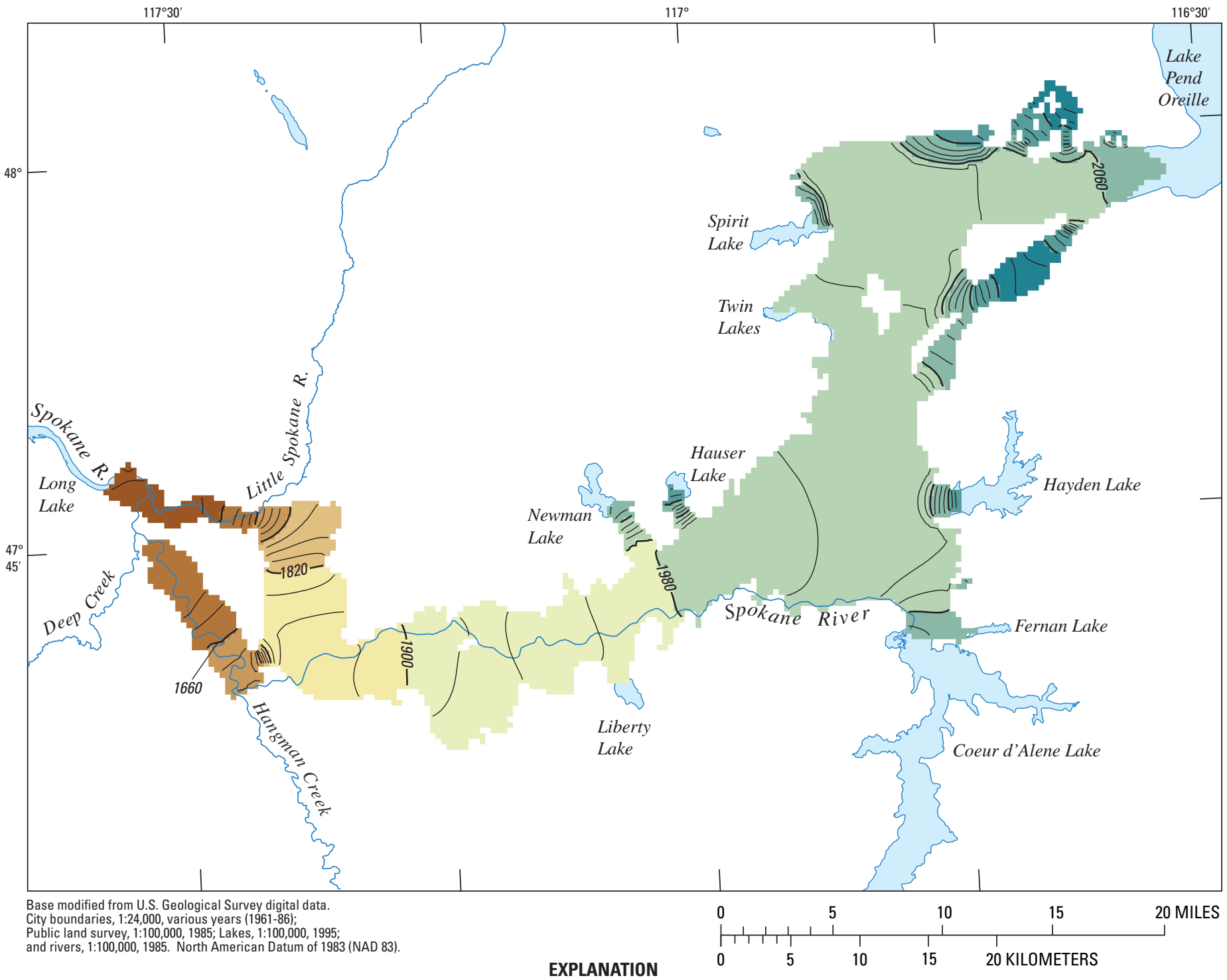

Altitude of simulated water level, in feet, in model layer 1, _ - 1400_ Simulated water-level contour-Shows altitude of water level, September 2004-Datum is North American Vertical Datum of 1988 September 2004. Contour interval, 20 feet. Datum is North

\begin{tabular}{|c|c|}
\hline 2,220 to 2,300 & 1,820 to 1,900 \\
\hline 2,140 to 2,220 & 1,740 to 1,820 \\
\hline 2,060 to 2,140 & 1,660 to 174 \\
\hline 1,980 to 2,060 & 1,580 to 1,660 \\
\hline 1,900 to 1,980 & 1,500 to 1,580 \\
\hline
\end{tabular}

Figure 42. Simulated water levels in model layer 1, Spokane Valley-Rathdrum Prairie aquifer, Washington and Idaho, September 2004. 


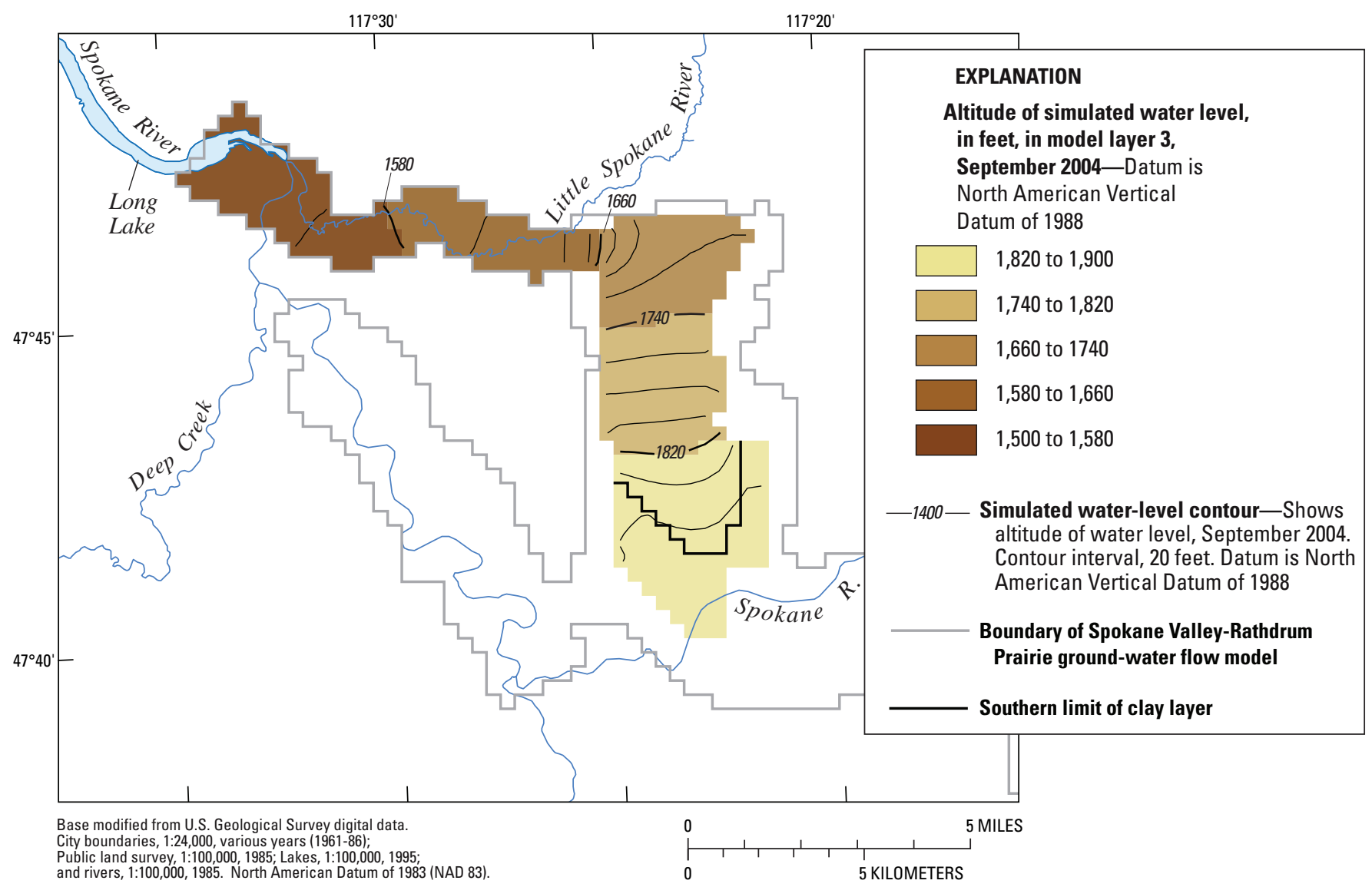

Figure 43. Simulated water levels in model layer 3, Spokane Valley-Rathdrum Prairie aquifer, Washington and Idaho, September 2004.

Simulated and measured monthly average streamflow gains and losses for the Spokane River segments from the gaging stations near Post Falls to at Spokane, near Post Falls to at Greenacres, and at Greenacres to at Spokane are shown in figure 44. The length of the vertical line extending above or below a plotted point indicates the measurement error, calculated as 1.96 times the standard deviation used in the calculation of measurement weights. During times of high streamflow (winter and spring), measurement errors can be very large. The simulated streamflow gains and losses generally agree with the measured gains and losses during late summer, when streamflow is low and the measurement error is small.

For the Spokane River segment from the gaging stations near Post Falls to at Greenacres (ig. 44B), data show a decrease in the magnitude of streamflow loss during the first halves of 2003 and 2004 when the river stage is high. This is an unexpected phenomenon because the altitude of the bottom of the riverbed from the gaging stations near Post Falls to at Greenacres is always above the water table. Therefore, the magnitude of streamflow loss is expected to increase (as indicated by the simulated quantity) during winter and spring when the river stage is high. If the measured streamflow at the gaging station at Greenacres is inaccurate (too low) during the first halves of 2003 and 2004, the error might account for the poorer fit during the same two periods for the segment from gaging stations at Greenacres to at Spokane (fig. 44C).

The simulated and measured monthly average streamflow gains on the Little Spokane River from the gaging stations at Dartford to near Dartford are in overall agreement as shown in figure 45. The simulated streamflow gain represents the regional discharge from the SVRP aquifer and is remarkably constant. The measured streamflow gain exhibits fluctuations during winter and spring. Nonetheless, the simulated gains are within the error bounds of the measured gains.

Simulated and measured streamflow gains and losses on various Spokane River segments during the seepage runs of September 13-16, 2004, and August 26-31, 2005, are shown in figure 46. The measurements made during the seepage runs might be characterized as nearly instantaneous. By contrast, the simulated streamflow gains and losses represent quantities averaged over a stress period (1 month). Nonetheless, the simulated and measured quantities are in relatively good agreement. 


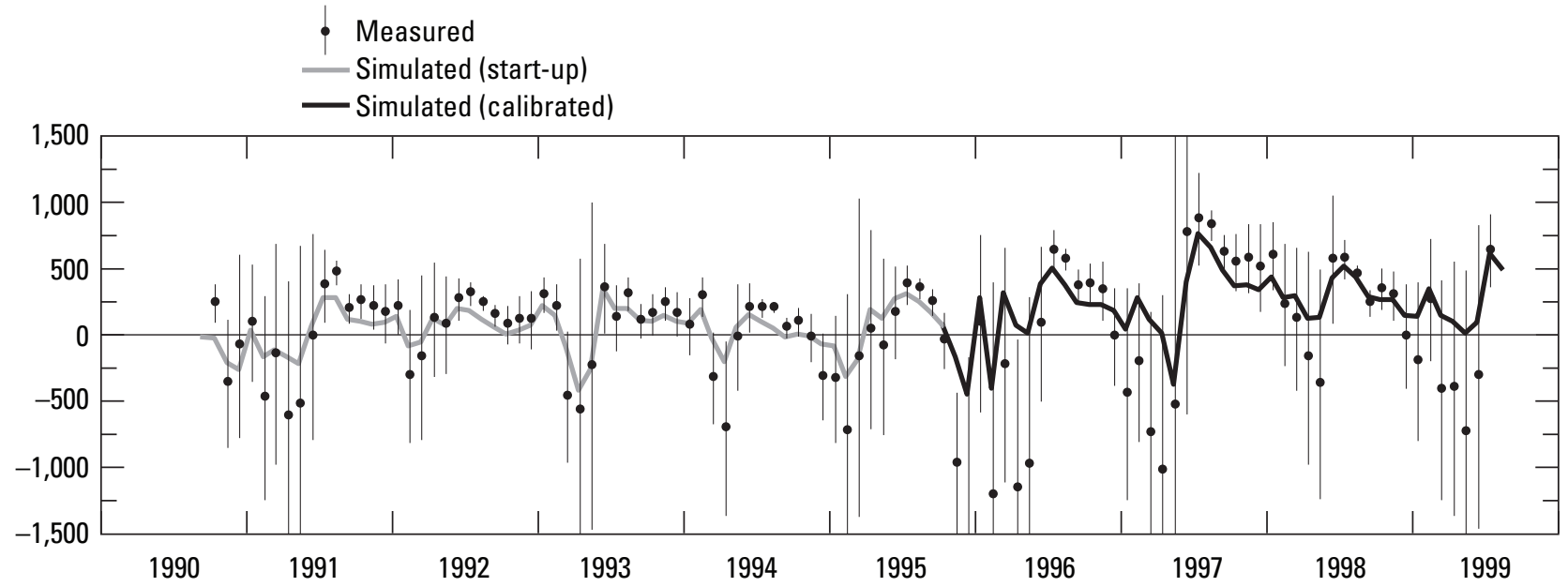

A. Simulated and measured streamflow gains (positive values) or losses (negative values) on the Spokane River segment from gaging stations near Post Falls to at Spokane.

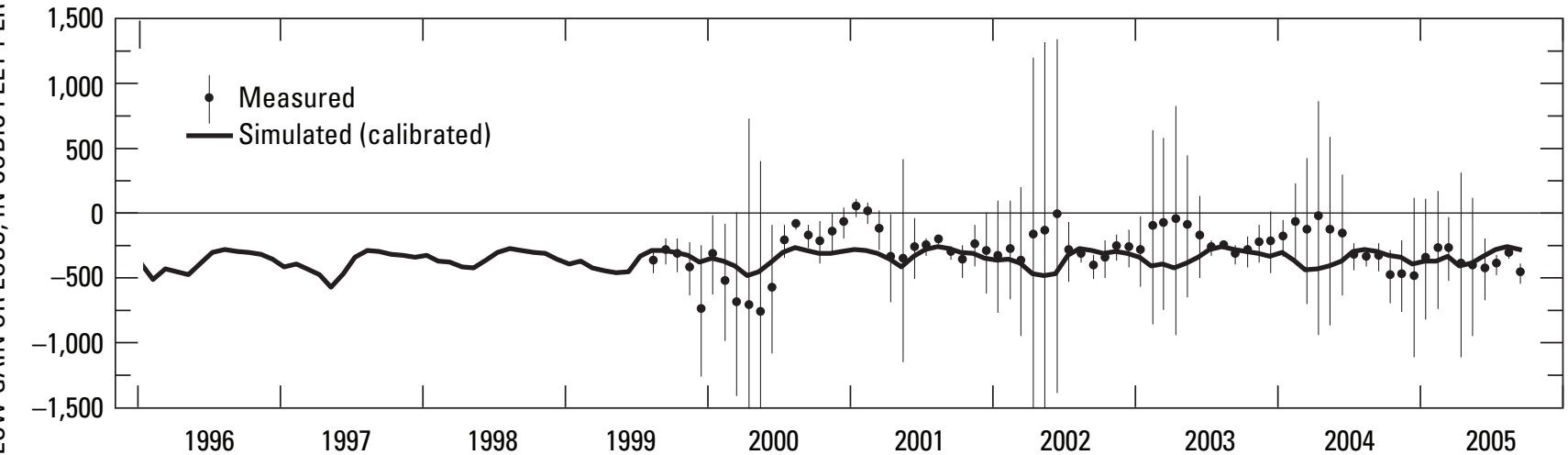

B. Simulated and measured streamflow gains (positive values) or losses (negative values) on the Spokane River segment from gaging stations near Post Falls to at Greenacres.

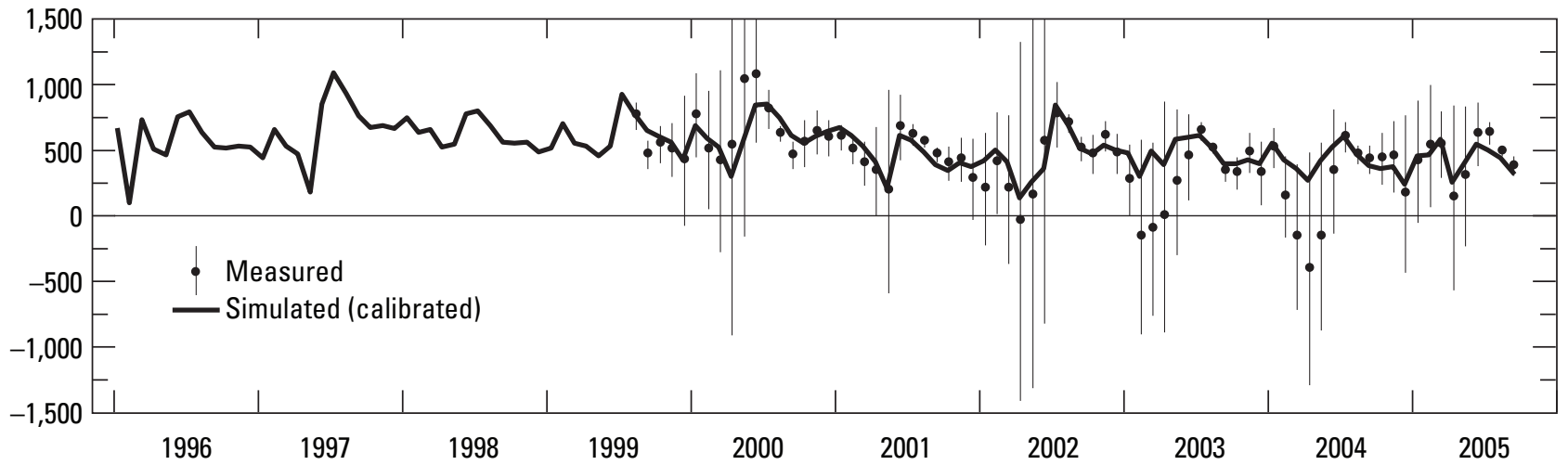

C. Simulated and measured streamflow gains (positive values) or losses (negative values) on the Spokane River segment from gaging stations at Greenacres to at Spokane.

Figure 44. Simulated and measured monthly average streamflow gains and losses for three Spokane River segments, Spokane Valley-Rathdrum Prairie aquifer, Washington and Idaho. 


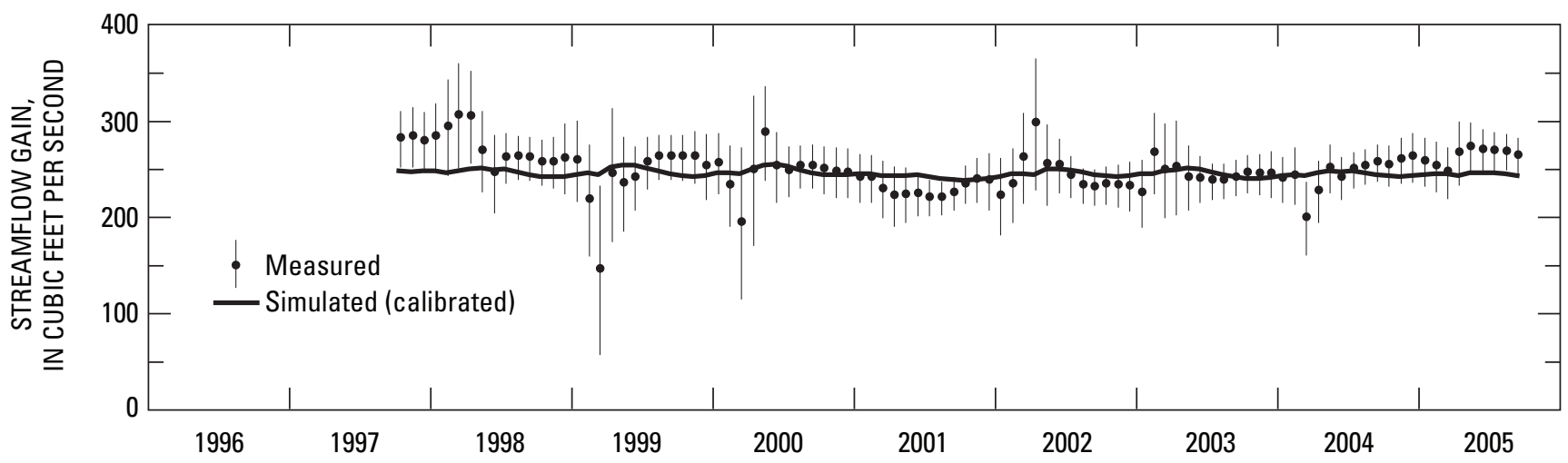

Figure 45. Simulated and measured monthly average streamflow gains on the Little Spokane River from the gaging stations at Dartford to near Dartford.

Measured $\square$ Simulated
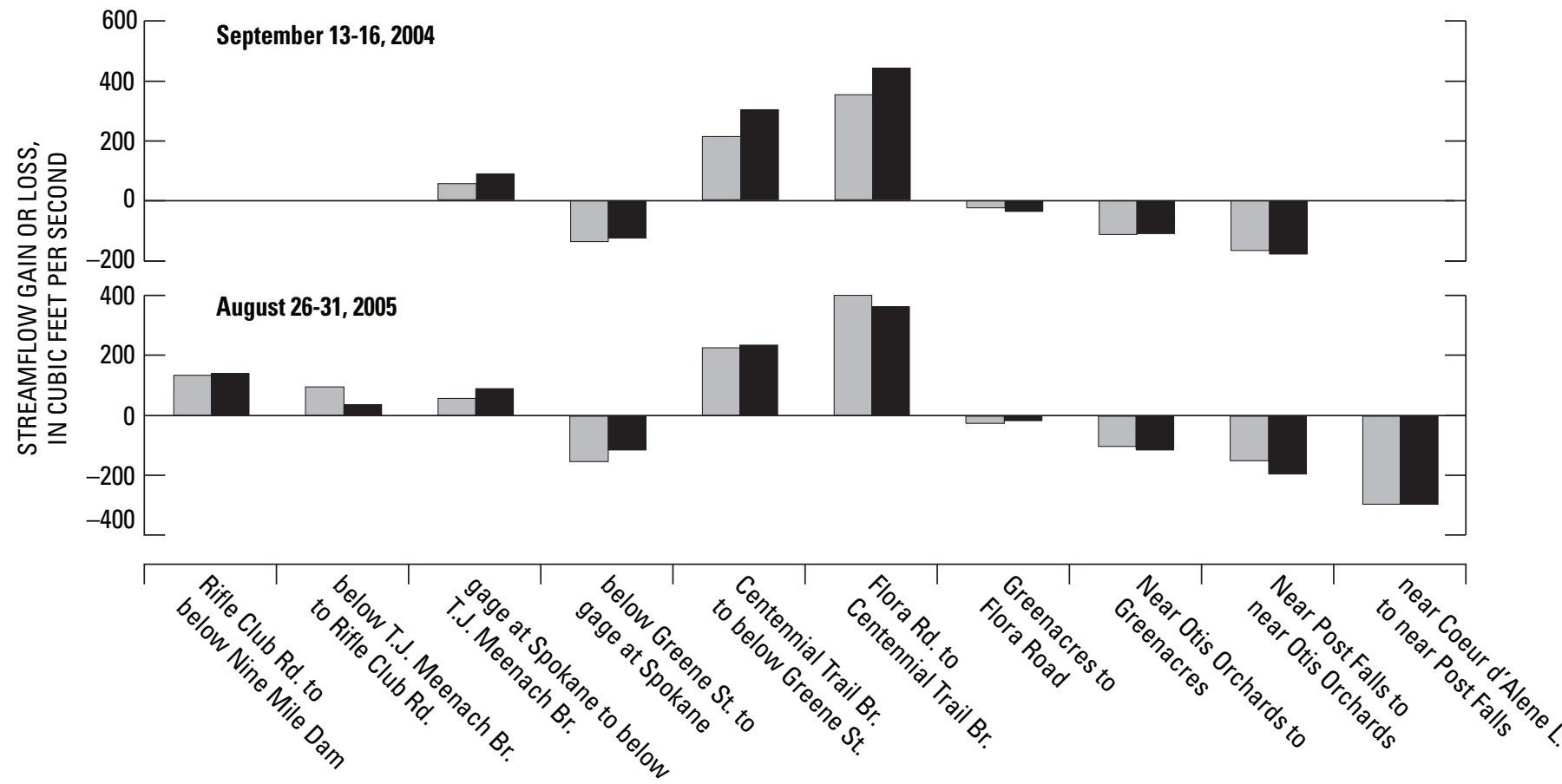

Figure 46. Simulated and measured streamflow gains (positive values) and losses (negative values) on various segments of the Spokane River during seepage runs of September 13-16, 2004, and August 26-31, 2005. 
Simulated and measured streamflow gains and losses on three Little Spokane River segments during the seepage runs of September 13-16, 2004, and August 26-31, 2005, are shown in figure 47 . The simulated streamflow gains and losses are close to the measured streamflow gains and losses except for the river segment from the gaging station near Dartford to the streamflow measurement site near the mouth of the river. For this segment, the data indicate a small streamflow loss. As discussed previously, this Little Spokane River is not expected to lose streamflow in the Little Spokane River Arm of the SVRP aquifer because this is an area of ground-water discharge. The calibrated model simulates essentially no interaction between the aquifer and this segment of the Little Spokane River.

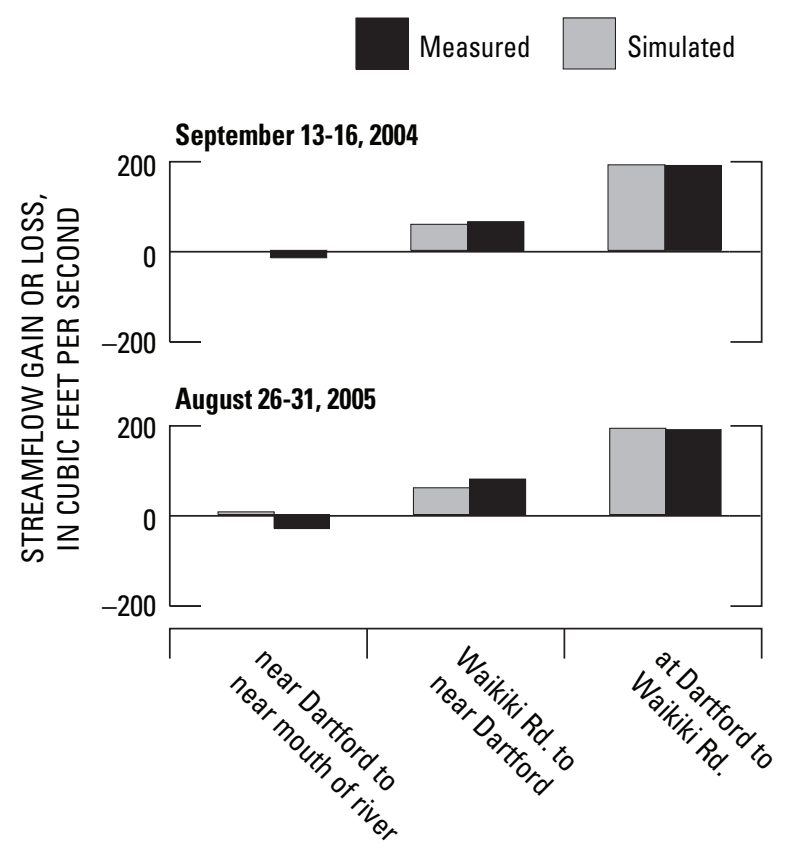

Figure 47. Simulated and measured streamflow gains (positive values) and losses (negative values) on three Little Spokane River segments during seepage runs of September 13-16, 2004, and August 26-31, 2005.
The spatial distribution of weighted water-level residuals in model layer 1 during September 2004 is shown in figure 48. Ideally, weighted residuals should be distributed randomly throughout the model area. In figure 48, however, the positive weighted residuals tend to cluster locally with other positive weighted residuals, and the negative weighted residuals tend to cluster locally with other negative weighted residuals. The clustering likely is caused by the representation of aquifer properties by zones of uniform values. This simplification might be considered a source of model error in the sense that such error can be reduced by implementing a more complex distribution of aquifer properties in the model. Nonetheless, zonation is widely accepted as a useful approach for model calibration. Although the spatial distribution of weighted residuals shown in figure 48 cannot be characterized as an ideal distribution, the distribution does not show signs of gross model errors over large parts of the aquifer.

The weighted water-level residuals and simulated water levels are shown in figure 49. The plotted points show a fairly random distribution of weighted residuals above and below zero for all simulated water levels. This feature indicates that the simulated water levels fit measured water levels as well in an upgradient region (such as northern Rathdrum Prairie) as in a downgradient region (such as Western Arm). Similarly, the plotted points for weighted flow residuals and simulated streamflow gains and losses (fig. 50) show a fairly random distribution of points above and below zero for all simulated quantities. This feature indicates that the simulated flows fit the measured flows as well in a gaining river segment as in a losing river segment. The vertical band of points shown in figure 50 corresponds to weighted flow residuals for the Little Spokane River. The cluster pattern results from the fact that simulated streamflow gains on the Little Spokane River are relatively constant over time whereas the measured streamflow gains show fluctuations during the winter and spring (fig. 45). 


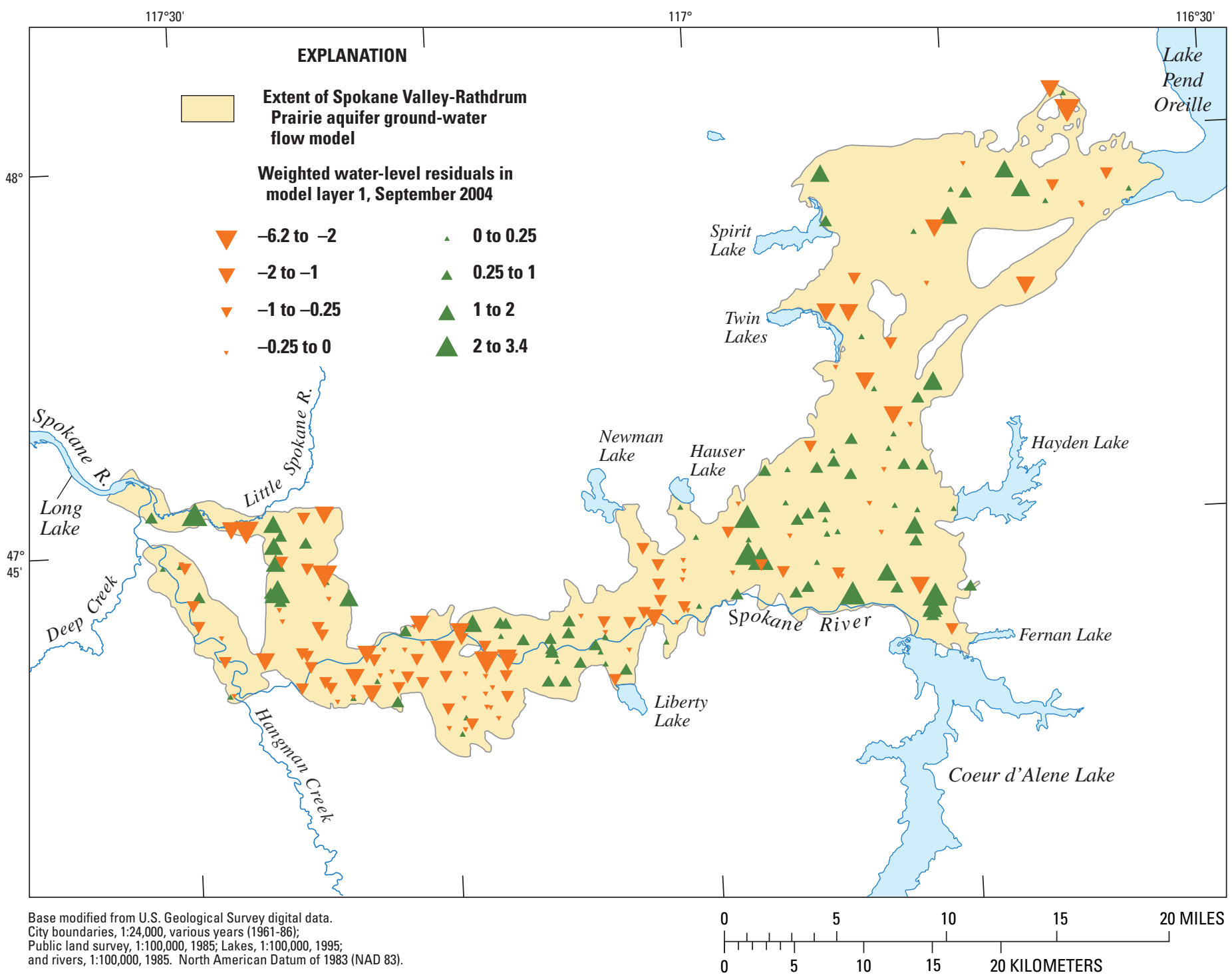

Figure 48. Spatial distribution of weighted water-level residuals in model layer 1, September 2004, Spokane Valley-Rathdrum Prairie aquifer, Washington and Idaho.

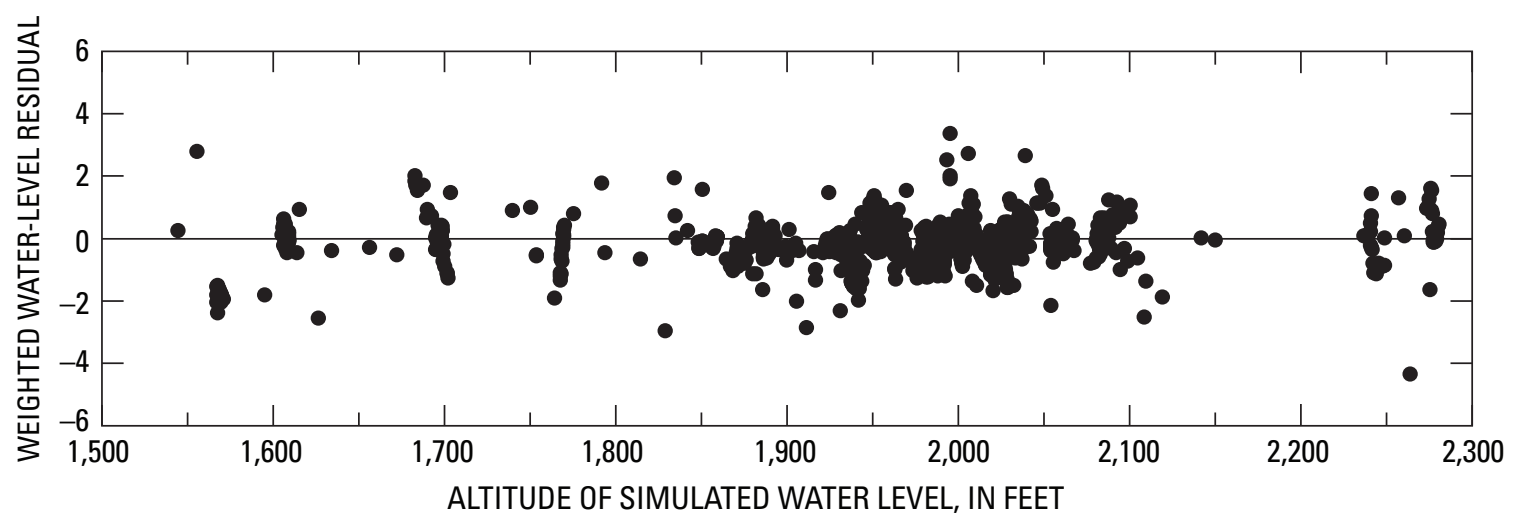

Figure 49. Weighted water-level residuals and simulated water levels. 


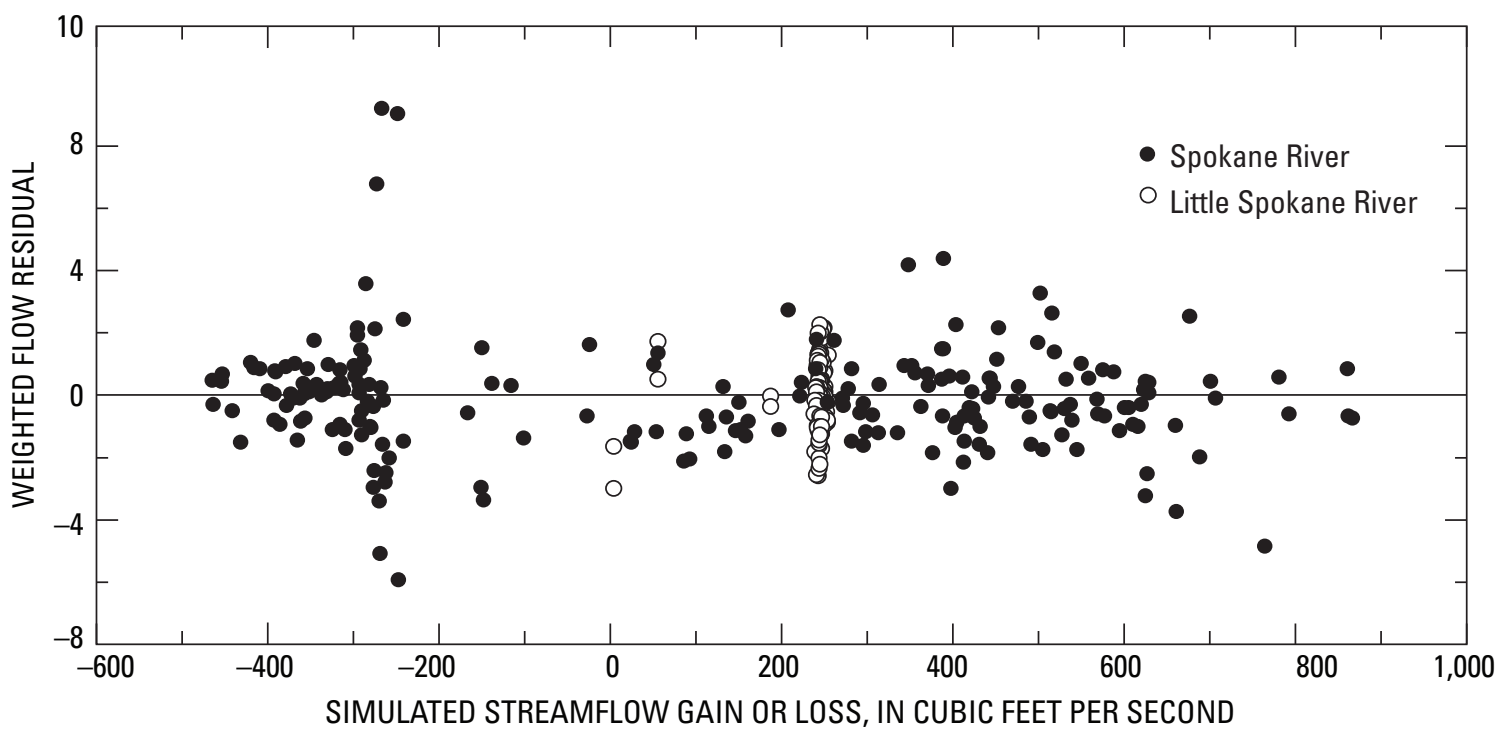

Figure 50. Weighted flow residuals and simulated streamflow gains (positive values) or losses (negative values).

\section{Simulated Flows in Aquifer}

To examine simulated ground-water movement, the SVRP aquifer is divided into eight subregions, seven of which are shown in figure 51. The eighth subregion is the lower unit, which underlies Hillyard Trough and the Little Spokane River Arm. For each subregion, simulated inflows, outflows, and change in storage are averaged over the model calibration period from October 1995 to September 2005 and are given under the Calibrated Model column in table 9. Additional columns in table 9 contain water-budget components for alternative models discussed in the next section of this report. Note that quantities averaged over the 10-year calibration period have slightly different values than the corresponding 15-year averaged quantities given in the sections, "Inflows to Aquifer" and "Outflows from Aquifer".

For each subregion, inflow components include recharge from precipitation, flow from tributary basins, flow from lakes and losing segments of rivers, and flow from the upstream subregion. Outflow components include net water use (well withdrawals minus return percolation from irrigation and effluent from septic systems), flow to gaining segments of rivers, and flow to the downstream subregion.

Many of the flow components in the subregional water budget are specified in the model. These components are shown in italic and include recharge from precipitation, net water use, and flow to the aquifer from tributary basins and from all lakes except Lake Pend Oreille and Coeur d'Alene Lake. In addition, the model is calibrated to fit measured flows between the aquifer and the Spokane and Little Spokane
Rivers. Therefore, the flow components that are neither specified nor constrained by calibration data are: (1) inflow to the aquifer from Lake Pend Oreille, (2) inflow to the aquifer from Coeur d'Alene Lake, and (3) outflow from the aquifer (lower unit) to Long Lake. The calibrated model gives a 10year average flow of $67 \mathrm{ft}^{3} / \mathrm{s}$ from Lake Pend Oreille to the aquifer, $138 \mathrm{ft}^{3} / \mathrm{s}$ from Coeur d'Alene Lake to the aquifer, and $27 \mathrm{ft}^{3} / \mathrm{s}$ from the lower unit to Long Lake.

On the east side of the aquifer, flow from a subregion to the adjacent downgradient subregion increases along the direction of ground-water flow. The simulated 10-year average flow from northern Rathdrum Prairie to southern Rathdrum Prairie is $286 \mathrm{ft}^{3} / \mathrm{s}$, of which 72 percent flows through West Channel, 26 percent flows through Ramsey Channel, and 2 percent flows through Chilco Channel (table 9, fig. 51). The simulated 10-year average flow from southern Rathdrum Prairie to eastern Spokane Valley is $823 \mathrm{ft}^{3} / \mathrm{s}$. The boundary between eastern Spokane Valley and the Spokane area coincides with Sullivan Road, which crosses the Spokane River near the point where the river changes from a losing stream to a gaining stream. The simulated 10-year average flow from eastern Spokane Valley to the Spokane area is 1,280 $\mathrm{ft}^{3} / \mathrm{s}$.

From the Spokane area, the simulated 10-year average outflows are $623 \mathrm{ft}^{3} / \mathrm{s}$ to the Spokane River, $288 \mathrm{ft}^{3} / \mathrm{s}$ to Hillyard Trough, and $264 \mathrm{ft}^{3} / \mathrm{s}$ through Trinity Trough to Western Arm. From Hillyard Trough, the simulated 10-year average outflows are $254 \mathrm{ft}^{3} / \mathrm{s}$ to the upper unit in Little Spokane River Arm (and eventually to the Little Spokane River) and $27 \mathrm{ft}^{3} / \mathrm{s}$ to the lower unit (and eventually to Long Lake). 


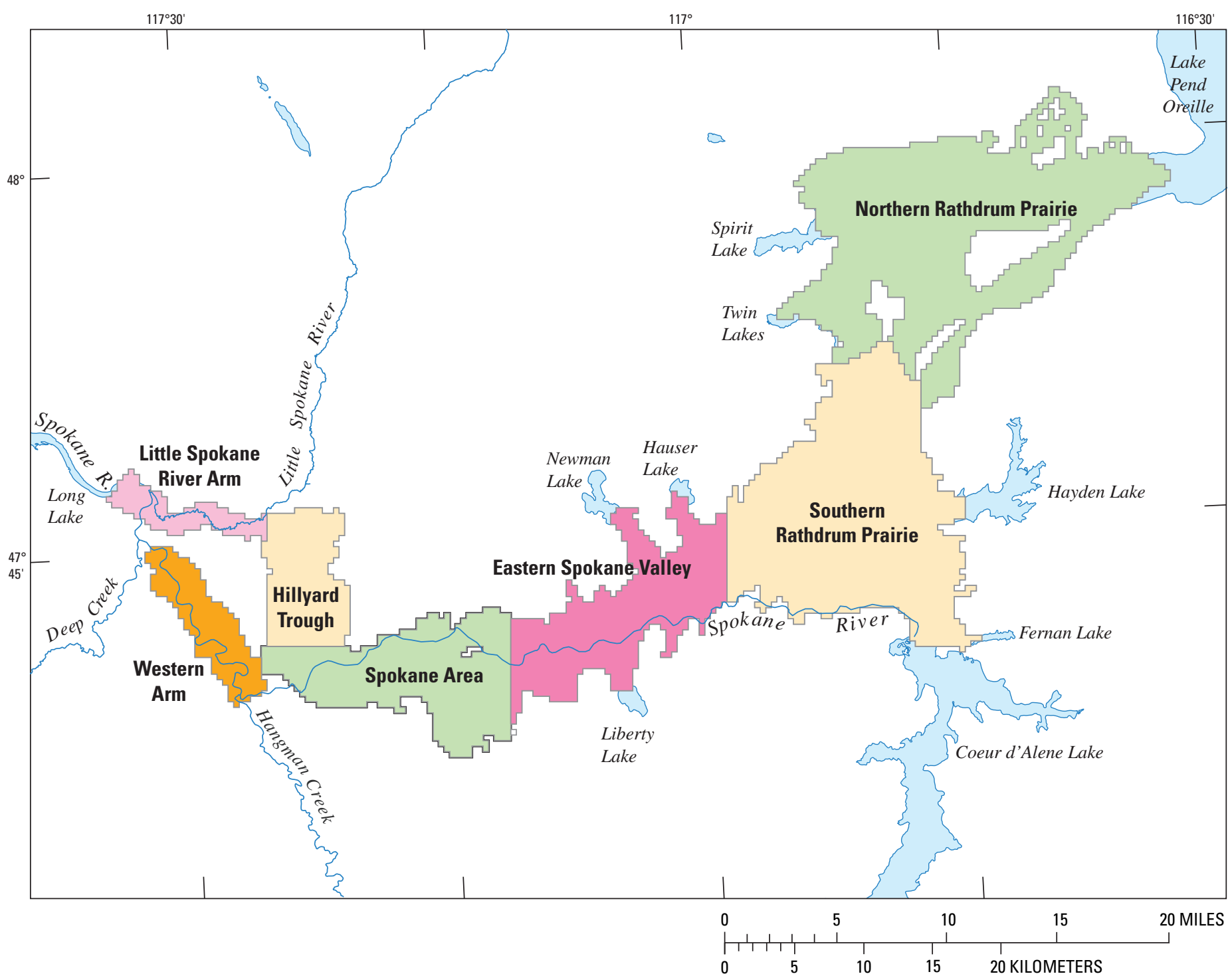

Figure 51. Subregions of the Spokane Valley-Rathdrum Prairie aquifer for water-budget calculations.

\section{Alternative Models}

To examine the assumptions in the SVRP aquifer model, five alternative models are analyzed. In each alternative model, one aspect of the calibrated model is modified and the alternative model is recalibrated. Estimated values of parameters and regression statistics from the calibrated and alternative models are given in tables 10 and $\underline{11}$.
In alternative model $\mathrm{A}$, the value of HK1-15 $\left(\mathrm{K}_{n}\right.$ of the zone next to Coeur d'Alene Lake) is set to $500 \mathrm{ft} / \mathrm{d}$ (table 9). This value is similar to the hydraulic conductivity value used in Sagstad's (1977) Darcy's Law calculation of seepage from Coeur d'Alene Lake (see section, "Lakebed Seepage and Surface Overflow"). In the calibrated model, the value of HK1-15 is 1,290 ft/d and the simulated 10-year average seepage from Coeur d'Alene Lake is $138 \mathrm{ft}^{3} / \mathrm{s}$. Using a lower 
value of HK1-15 in alternative model A effectively limits the seepage from Coeur d'Alene Lake. Compared to the calibrated model, alternative model $\mathrm{A}$ has higher $\mathrm{K}_{\mathrm{h}}$ values in northern Rathdrum Prairie (HK1-1, HK1-2, and HK1-3) and a lower conductance value for the Coeur d'Alene lakebed sediments (C-CDA) (table 10). The simulated 10-year average seepage from Lake Pend Oreille to the aquifer increases to $107 \mathrm{ft}^{3} / \mathrm{s}$ (table 9), and the simulated 10-year average seepage from
Coeur d'Alene Lake to the aquifer decreases to $29 \mathrm{ft}^{3} / \mathrm{s}$, which is close to Sagstad's (1977) estimated of $37 \mathrm{ft}^{3} / \mathrm{s}$. However, as shown in table 11, the sum of squared weighted residuals from alternative model $\mathrm{A}$ is only about 1 percent higher than that from the calibrated model. This indicates that the simulated quantities from alternative model A fit the measured quantities nearly as well as the simulated quantities from the calibrated model.

Table 9. Simulated 10-year average water budget for subregions of the Spokane Valley-Rathdrum Prairie aquifer.

[Values are in cubic foot per second. Value in italic indicates flow component is specified; value in bold indicates flow component is not specified]

\begin{tabular}{|c|c|c|c|c|c|c|c|c|}
\hline & & & Calibrated & & & ternative & odel & \\
\hline & & & model & A & B & C & D & E \\
\hline northern & Inflow & $\begin{array}{l}\text { recharge from precipitation } \\
\text { tributary basins } \\
\text { Lake Pend Oreille } \\
\text { Spirit Lake } \\
\text { Twin Lakes } \\
\end{array}$ & $\begin{array}{l}77 \\
63 \\
67 \\
55 \\
40\end{array}$ & $\begin{array}{r}77 \\
63 \\
107 \\
55 \\
40\end{array}$ & $\begin{array}{l}77 \\
63 \\
65 \\
55 \\
40\end{array}$ & $\begin{array}{l}77 \\
63 \\
64 \\
55 \\
40\end{array}$ & $\begin{array}{r}77 \\
108 \\
95 \\
55 \\
40\end{array}$ & $\begin{array}{l}77 \\
63 \\
75 \\
55 \\
40\end{array}$ \\
\hline $\begin{array}{l}\text { Rathorum } \\
\text { Prairie }\end{array}$ & Outflow & \begin{tabular}{|l} 
net water use \\
West Channel \\
Ramsey Channel \\
Chilco Channel \\
\end{tabular} & $\begin{array}{r}-6 \\
-206 \\
-75 \\
-5 \\
\end{array}$ & $\begin{array}{r}-6 \\
-235 \\
-87 \\
-5 \\
\end{array}$ & $\begin{array}{r}-6 \\
-204 \\
-75 \\
-5\end{array}$ & $\begin{array}{r}-6 \\
-204 \\
-75 \\
-5\end{array}$ & $\begin{array}{r}-6 \\
-259 \\
-96 \\
-5\end{array}$ & $\begin{array}{r}-6 \\
-212 \\
-78 \\
-5\end{array}$ \\
\hline & Decrease & Storage & -9 & -9 & -9 & -9 & -9 & -9 \\
\hline $\begin{array}{l}\text { southern } \\
\text { Rathdrum } \\
\text { Prairie }\end{array}$ & Inflow & $\begin{array}{l}\text { West Channel } \\
\text { Ramsey Channel } \\
\text { Chilco Channel } \\
\text { recharge from precipitation } \\
\text { tributary basins } \\
\text { Hayden Lake } \\
\text { Fernan Lake } \\
\text { Coeur d'Alene Lake } \\
\text { Spokane River }\end{array}$ & $\begin{array}{r}206 \\
75 \\
5 \\
74 \\
20 \\
70 \\
15 \\
\mathbf{1 3 8} \\
\mathbf{2 7 4}\end{array}$ & $\begin{array}{r}235 \\
\mathbf{8 7} \\
\mathbf{5} \\
74 \\
20 \\
70 \\
15 \\
\mathbf{2 9} \\
\mathbf{2 8 7}\end{array}$ & $\begin{array}{r}\mathbf{2 0 4} \\
\mathbf{7 5} \\
\mathbf{5} \\
74 \\
20 \\
70 \\
15 \\
\mathbf{1 7 5} \\
\mathbf{2 7 6}\end{array}$ & $\begin{array}{r}\mathbf{2 0 4} \\
\mathbf{7 5} \\
\mathbf{5} \\
74 \\
20 \\
70 \\
15 \\
\mathbf{1 3 2} \\
\mathbf{2 7 2}\end{array}$ & $\begin{array}{r}259 \\
\mathbf{9 6} \\
\mathbf{5} \\
74 \\
20 \\
70 \\
15 \\
104 \\
\mathbf{2 6 5}\end{array}$ & $\begin{array}{r}\mathbf{2 1 2} \\
\mathbf{7 8} \\
\mathbf{5} \\
74 \\
20 \\
70 \\
15 \\
\mathbf{1 3 7} \\
\mathbf{2 7 3}\end{array}$ \\
\hline & Outflow & $\begin{array}{l}\text { net water use } \\
\text { eastern Spokane Valley }\end{array}$ & $\begin{array}{r}-57 \\
-823\end{array}$ & $\begin{array}{r}-57 \\
-769\end{array}$ & $\begin{array}{r}-57 \\
\mathbf{- 8 6 1}\end{array}$ & $\begin{array}{r}-57 \\
\mathbf{- 8 1 3}\end{array}$ & $\begin{array}{r}-57 \\
\mathbf{- 8 5 5} \\
\end{array}$ & $\begin{array}{r}-57 \\
\mathbf{- 8 3 0}\end{array}$ \\
\hline & Decrease & Storage & 4 & 4 & 4 & 4 & 5 & 4 \\
\hline $\begin{array}{l}\text { eastern } \\
\text { Spokane } \\
\text { Valley }\end{array}$ & Inflow & $\begin{array}{l}\text { southern Rathdrum Prairie } \\
\text { recharge from precipitation } \\
\text { tributary basins } \\
\text { Hauser Lake } \\
\text { Newman Lake } \\
\text { Liberty Lake } \\
\text { Spokane River }\end{array}$ & $\begin{array}{r}823 \\
30 \\
16 \\
20 \\
23 \\
6 \\
377\end{array}$ & $\begin{array}{r}769 \\
30 \\
16 \\
20 \\
23 \\
6 \\
378\end{array}$ & $\begin{array}{r}861 \\
30 \\
16 \\
20 \\
23 \\
6 \\
378\end{array}$ & $\begin{array}{r}813 \\
30 \\
16 \\
20 \\
23 \\
6 \\
377\end{array}$ & $\begin{array}{r}855 \\
30 \\
16 \\
20 \\
23 \\
6 \\
377\end{array}$ & $\begin{array}{r}830 \\
30 \\
16 \\
20 \\
23 \\
6 \\
378\end{array}$ \\
\hline & Outflow & $\begin{array}{l}\text { net water use } \\
\text { Spokane area }\end{array}$ & $\begin{array}{r}-16 \\
-\mathbf{1 , 2 8 0}\end{array}$ & $\begin{array}{r}-16 \\
-\mathbf{1 , 2 2 7}\end{array}$ & $\begin{array}{r}-16 \\
-1,319\end{array}$ & $\begin{array}{r}-16 \\
-1,270\end{array}$ & $\begin{array}{r}-16 \\
-1,312 \\
\end{array}$ & $\begin{array}{r}-16 \\
-1,288 \\
\end{array}$ \\
\hline & Decrease & Storage & 2 & 2 & 2 & 2 & 2 & 2 \\
\hline
\end{tabular}


Table 9. Simulated 10-year average water budget for subregions of the Spokane Valley-Rathdrum Prairie aquiferContinued.

[Values are in cubic foot per second. Value in italic indicates flow component is specified; value in bold indicates flow component is not specified]

\begin{tabular}{|c|c|c|c|c|c|c|c|c|}
\hline & & & \multirow{2}{*}{$\begin{array}{l}\text { Calibrated } \\
\text { model }\end{array}$} & \multicolumn{5}{|c|}{ Alternative model } \\
\hline & & & & A & B & C & D & $\mathbf{E}$ \\
\hline \multirow{8}{*}{$\begin{array}{l}\text { Spokane } \\
\text { area }\end{array}$} & & eastern Spokane Valley & 1,280 & 1,227 & 1,319 & 1,270 & 1,312 & 1,288 \\
\hline & Inflow & recharge from precipitation & 30 & 30 & 30 & 30 & 30 & 30 \\
\hline & & tributary basins & & & 4 & 4 & 4 & \\
\hline & \multirow{4}{*}{ Outflow } & net water use & -133 & -133 & -133 & -133 & -133 & -133 \\
\hline & & Spokane River & -623 & -616 & -620 & -618 & -625 & -628 \\
\hline & & Hillyard Trough & -293 & -293 & -349 & -293 & -293 & -293 \\
\hline & & Western Arm & -264 & -218 & -249 & -260 & -295 & -268 \\
\hline & \multicolumn{2}{|c|}{ Decrease in Storage } & 0 & 0 & 0 & 0 & 0 & 0 \\
\hline \multirow{6}{*}{$\begin{array}{l}\text { Western } \\
\text { Arm }\end{array}$} & & Spokane area & 264 & 218 & 249 & 260 & 295 & 268 \\
\hline & Inflow & recharge from precipitation & 7 & 7 & 7 & 7 & 7 & 7 \\
\hline & & tributary basins & 16 & 16 & 16 & 16 & 16 & 16 \\
\hline & & net water use & -3 & -3 & -3 & -3 & -3 & -3 \\
\hline & Outflow & Spokane River & -283 & -238 & -269 & -280 & -314 & -287 \\
\hline & \multicolumn{2}{|c|}{ Decrease in Storage } & 0 & 0 & 0 & 0 & 0 & 0 \\
\hline \multirow{7}{*}{$\begin{array}{l}\text { Hillyard } \\
\text { Trough }\end{array}$} & & Spokane area & 293 & 293 & 349 & 293 & -293 & 293 \\
\hline & Inflow & recharge from precipitation & 14 & 14 & 14 & 14 & 14 & 14 \\
\hline & & tributary basins & 3 & 3 & 3 & 3 & 3 & 3 \\
\hline & & net water use & -28 & -28 & -28 & -28 & -28 & -28 \\
\hline & Outflow & Little Spokane River Arm & -254 & -254 & -254 & -254 & -254 & -254 \\
\hline & & Lower Unit & -27 & -27 & -84 & -27 & -27 & -27 \\
\hline & \multicolumn{2}{|c|}{ Decrease in Storage } & 0 & 0 & 0 & 0 & 0 & 0 \\
\hline \multirow{7}{*}{$\begin{array}{l}\text { Little } \\
\text { Spokane } \\
\text { River Arm }\end{array}$} & & Hillyard Trough & 254 & 254 & 254 & 254 & 254 & 254 \\
\hline & Inflow & recharge from precipitation & 5 & 5 & 5 & 5 & 5 & 5 \\
\hline & & tributary basins & 6 & 6 & 6 & 6 & 6 & 6 \\
\hline & & net water use & 0 & 0 & 0 & 0 & 0 & 0 \\
\hline & Outflow & Little Spokane River & -257 & -257 & -257 & -257 & -257 & -257 \\
\hline & & Spokane River/Long Lake & -8 & -8 & -8 & -8 & -8 & -8 \\
\hline & \multicolumn{2}{|c|}{ Decrease in Storage } & 0 & 0 & 0 & 0 & 0 & 0 \\
\hline \multirow{4}{*}{$\begin{array}{l}\text { Lower } \\
\text { Unit }\end{array}$} & Inflow & Hillyard Trough & 27 & 27 & 84 & 27 & 27 & 27 \\
\hline & \multirow{2}{*}{ Outflow } & net water use & 0 & 0 & 0 & 0 & 0 & 0 \\
\hline & & Long Lake & -27 & -27 & -84 & -27 & -27 & -27 \\
\hline & \multicolumn{2}{|c|}{ Decrease in Storage } & 0 & 0 & 0 & 0 & 0 & 0 \\
\hline
\end{tabular}


Table 10. Esitmated values of parameters for calibrated and alternative models.

[ft/d; foot per day; --, dimensionless; $\mathrm{ft}^{2} / \mathrm{d}$, foot squared per day; value in italic indicates that parameter is specified and not estimated]

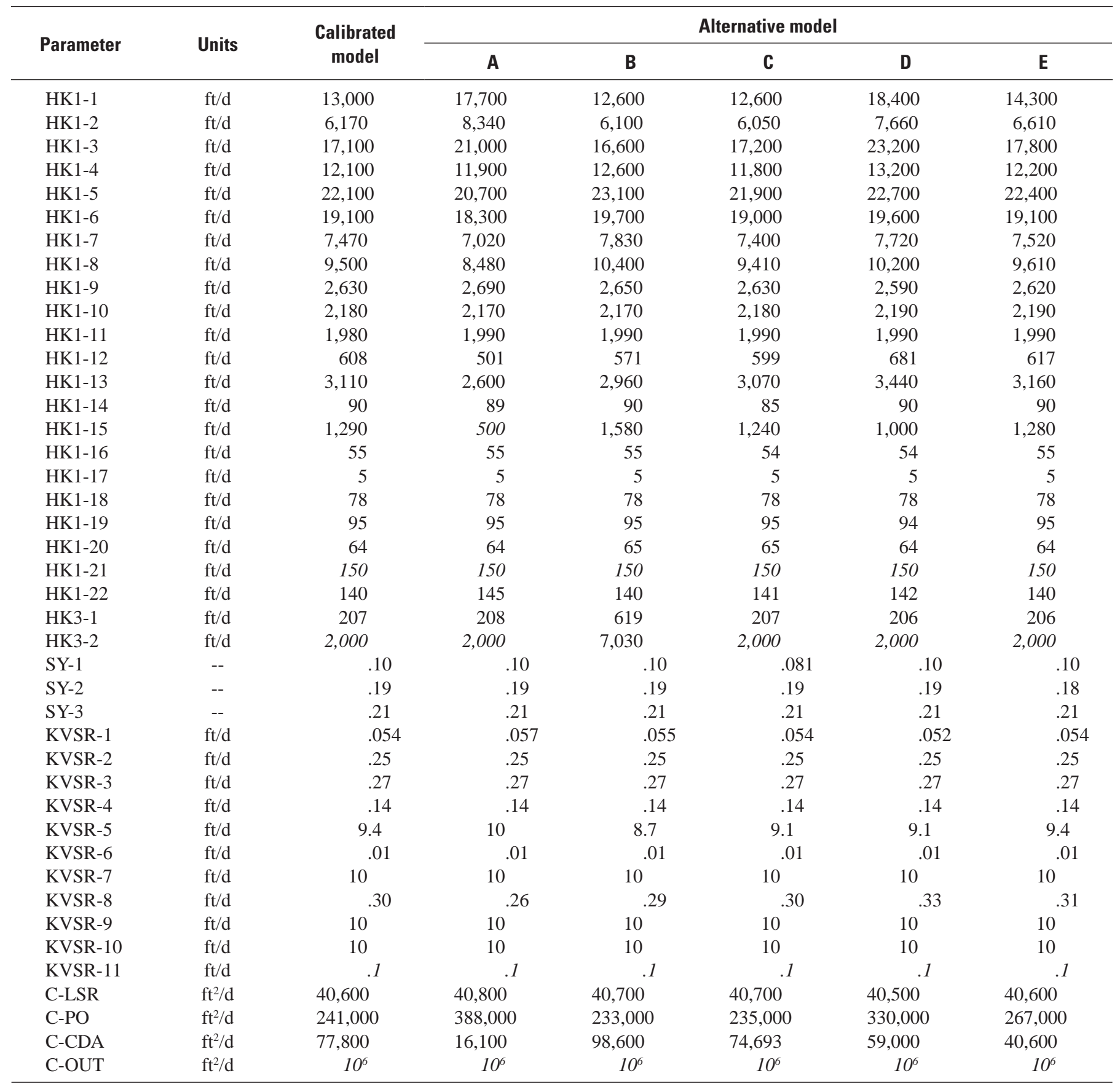


Table 11. Regression statistics for calibrated and alternative models.

\begin{tabular}{|c|c|c|c|c|c|c|c|}
\hline \multirow{2}{*}{\multicolumn{2}{|c|}{ Regression statistic }} & \multirow{2}{*}{$\begin{array}{c}\text { Calibrated } \\
\text { model }\end{array}$} & \multicolumn{5}{|c|}{ Alternative model } \\
\hline & & & A & B & C & D & $\mathbf{E}$ \\
\hline \multirow{5}{*}{$\begin{array}{l}\text { Sum of } \\
\text { squared } \\
\text { weighted } \\
\text { residuals }\end{array}$} & All & 1,500 & 1,512 & 1,472 & 1,497 & 1,514 & 1,520 \\
\hline & Water levels, model layer 1 & 590 & 601 & 590 & 589 & 598 & 602 \\
\hline & Water levels, model layer 3 & 74 & 74 & 47 & 74 & 74 & 77 \\
\hline & Spokane River gains and losses & 682 & 682 & 681 & 679 & 688 & 685 \\
\hline & Little Spokane River gains and losses & 155 & 155 & 154 & 155 & 154 & 156 \\
\hline \multicolumn{2}{|c|}{ Standard error of weighted residuals } & 0.901 & 0.905 & 0.893 & 0.900 & 0.905 & 0.896 \\
\hline
\end{tabular}

In alternative model $B$, the value of $\mathrm{HK} 3-2\left(\mathrm{~K}_{h}\right.$ values for the lower unit in the Little Spokane River Arm) is not specified but is estimated. The calibration yields an HK3-2 value of 7,030 ft/d (table 10). The simulated 10-year average flow from the lower unit to Long Lake increases to $83 \mathrm{ft}^{3} / \mathrm{d}$ (table 9). The sum of squared weighted residuals decreases to less than that of the calibrated model, indicating an improved fit to measured water levels in wells 99 and 115 . However, this improved fit is attained at the cost of allowing HK3-2 to take on a value substantially higher than the upper limit of the acceptable range for this parameter. The occurrence of this trade-off is an additional indication that the model might not accurately represent the lower unit.

In alternative model $\mathrm{C}$, the lower limit of the acceptable range for SY-1 is decreased from 0.1 to 0 . In this case, the calibration yields an SY-1 value of 0.08 (table 10). However, the estimated values and the regression statistics from alternative model $\mathrm{C}$ are very close to those from the calibrated model (table 9 and 11 ). This indicates that setting a lower limit of 0.1 for SY-1 results in just as good a fit as allowing SY-1 to take on an estimated value less than 0.1 .

In alternative model $\mathrm{D}$, an inflow of $40 \mathrm{ft}^{3} / \mathrm{s}$ is applied to the model boundary near Spirit and Hoodoo Valleys (boundary segment A-B in fig. 2). In the calibrated model, there is no inflow across this boundary segment to the aquifer. Compared to the calibrated model, alternative model D has higher $K_{h}$ values in northern Rathdrum Prairie (HK1-1, HK1-2, and HK1-3) (table 10). The simulated 10-year average seepages are $95 \mathrm{ft}^{3} / \mathrm{s}$ from Lake Pend Oreille and $104 \mathrm{ft}^{3} / \mathrm{s}$ from Coeur d'Alene Lake (table 9). As in alternative model A, the sum of squared weighted residuals from alternative model D is just slightly higher than that from the calibrated model (table 11). This indicates that amount of inflow from the model boundary near Spirit and Hoodoo Valleys cannot be determined reliably from calibration of the SVRP aquifer model with the present calibration data.
Alternative model $\mathrm{E}$ is a hybrid calibration that consists of a steady-state model in additional to the transient model. The steady-state model simulates average conditions for water year 2005 (October 2004 through September 2005). Simulated water levels and flows from the steady-state model are fitted to averages of water levels and flows measured during water year 2005. The purpose of simultaneously calibrating a transient and a steady-state model is to examine the use of the SVRP aquifer model for steady-state simulations.

In general, a steady-state model can be used to simulate average conditions over a period (for example, one year) if (1) heads throughout the aquifer at the beginning of the period are similar to the heads at the end of the period and (2) the model is linear or nearly linear with respect to head. Because the SVRP aquifer is a water-table aquifer, nonlinearity can occur along the aquifer margins, where saturated thickness is small. To avoid such nonlinearity, measured water levels along the aquifer margins are excluded from the steady-state calibration data, with the understanding that the steady-state model might not accurately simulate water levels along the aquifer margins.

The sum of squared weighted residuals from alternative model $\mathrm{E}$ is higher than that from the calibrated model (table 11), because the hybrid calibration involves additional residuals. However, the estimated parameter values in alternative model $\mathrm{E}$ are in close agreement with the corresponding values in the calibrated model (table 10). This indicates that a steady-state model can be used to simulate average conditions during water year 2005 with reasonable accuracy (except for water levels along the aquifer margins). The applicability of the steady-state model is due to the fact that heads throughout the aquifer at the beginning of the water year (October 2004) are similar to heads at the end of the water year (September 2005). By contrast, applying the steady-state model to simulate average conditions for water year 1998 might lead to inaccurate results because water levels in Rathdrum Prairie rose about $15 \mathrm{ft}$ from the beginning of the water year to the end of the water year (fig. 27). 


\section{Model Limitations and Suggestions for Future Work}

Although the SVRP aquifer model presented in this report provides a relatively good fit between simulated and measured quantities, indicating that the overall simulated ground-water flow is a reasonable representation of groundwater flow in the SVRP aquifer, the model is subject to limitations. These limitations, discussed in the following paragraphs, should be taken into consideration when using the model.

In general, the scale of the model and the level of detail are intended for analysis of aquifer-wide water-supply issues. Although the model might be useful for providing boundary conditions for smaller scale investigations, the model lacks sufficient details for direct application to smallscale investigations such as the analysis of capture zone for an individual well. Additionally, the model is not intended for application to contaminant-transport issues such as the prediction of contaminant traveltimes or flow paths. A contaminant-transport model would require a substantially greater amount of hydrogeologic detail for the contamination site.

There is insufficient hydrologic information to determine ground-water inflow from Spirit and Hoodoo Valleys to the SVRP aquifer. The calibrated model in this report assumes no inflow from Spirit and Hoodoo Valleys. However, alternative model D indicates that the amount of inflow from the Spirit and Hoodoo Valleys cannot be determined reliably from model calibration with the present calibration data. Monitoring water levels in and near Spirit and Hoodoo Valleys could provide important data to better evaluate inflows from those valleys to the SVRP aquifer.

In Hillyard Trough and the Little Spokane River Arm, ground-water flow in the lower unit is not well understood. Water levels in the lower unit are monitored in only two wells, and the horizontal and vertical extents of the clay layer separating the upper and lower units are not well known. The model assumes that the clay layer completely isolates hydraulic contact between the lower and upper units, but this assumption requires critical evaluation. Monitoring water levels and conducting aquifer tests in both the upper and lower units might lead to better understanding of the hydrogeology in Hillyard Trough and Little Spokane River Arm.

There is significant uncertainty in the simulated seepages from Lake Pend Oreille and Coeur d'Alene Lake. In addition, the water-level fluctuations in wells near Coeur d'Alene Lake are not well understood. A detailed study of ground-water flow in the Coeur d'Alene area, including aquifer tests to estimate hydraulic conductivity in the vicinity of Coeur d'Alene Lake, might provide data that can be used to constrain the simulated seepage from Coeur d'Alene Lake.

\section{Summary and Conclusions}

The ground-water flow model presented in this report is a component of a comprehensive study initiated by the Idaho Department of Water Resources, the Washington Department of Ecology, and the U.S. Geological Survey to improve the understanding of ground-water flow in the Spokane Valley-Rathdrum Prairie (SVRP) aquifer and of the interaction between ground water and surface water. The model was developed by the Modeling Team formed within the comprehensive study. The Modeling Team consisted of staff and personnel working under contract with the Idaho Department of Water Resources, personnel working under contract with the Washington Department of Ecology, and staff of the U.S. Geological Survey. To arrive at a final model that has the endorsement of all team members, decisions on modeling approach, methodology, assumptions, and interpretations were reached by consensus. The primary purpose of the model is to serve as a tool for analyzing aquifer inflows and outflows, simulating the effects of future changes in ground-water withdrawals from the aquifer, and for evaluating aquifer management scenarios. The scale of the model and the level of detail are intended for analysis of aquifer-wide water-supply issues.

The SVRP aquifer model encompasses an area of approximately 326 square miles. For the most part, the model extent coincides with the 2005 revised extent of the SVRP aquifer as defined in previous reports. However, the model excludes Spirit and Hoodoo Valleys because of uncertainties about the ground-water flow directions in those valleys and the degree of hydraulic connection between the valleys and northern Rathdrum Prairie. In addition, the model excludes three areas, one in northern Rathdrum Prairie and two in the vicinity of Five Mile Prairie, because the aquifer sediments in those areas likely are unsaturated.

The SVRP aquifer is considered to be a single hydrogeologic unit except in Hillyard Trough and the Little Spokane River Arm. In those areas, a continuous clay layer divides the aquifer into an upper, unconfined unit and a lower, confined unit. Both the upper and lower units extend from Hillyard Trough toward the west through the Little Spokane River Arm. The model terminates at the east end of Long Lake, a reservoir on the Spokane River. At this model boundary, the upper unit is in direct hydraulic connection with Long Lake. Available field data indicate that the clay layer and lower unit extend beyond the model boundary for an unknown distance. However, the confining clay layer eventually pinches out, allowing ground water in the lower unit to discharge into Long Lake.

The SVRP aquifer model includes all known components of inflows to and outflows from the aquifer. Inflows to the SVRP aquifer include (1) recharge from precipitation, (2) inflows from tributary basins and adjacent uplands, 
(3) subsurface seepage and surface overflows from lakes that border the aquifer, (4) flow from losing segments of the Spokane River to the aquifer, (5) return percolation from irrigation, and (6) effluent from septic systems. Outflows from the SVRP aquifer include (1) ground-water withdrawals from wells, (2) flow from the aquifer to gaining segments of the Spokane River, (3) aquifer discharge to the Little Spokane River, and (4) subsurface outflow from the lower unit at the western limit of the model area near Long Lake.

The ground-water flow model MODFLOW-2000 is used to simulate ground-water flow in the SVRP aquifer. The finitedifference model grid consists of 172 rows, 256 columns, and 3 layers. Ground-water flow is simulated for September 1990 through September 2005 using 181 stress periods of 1 month each. Aquifer heads at the start of the simulation period are unknown, and the ground-water flow system was assumed to be at a steady state during the first stress period. Because aquifer heads simulated during this stress period serve as the initial conditions for the rest of the transient simulation, the first 5 years of the simulation period is considered to be a start-up period. No attempt is made to fit simulated quantities to measured quantities during the start-up period. Instead, the model is calibrated using water-level and flow data for October 1995 to September 2005.

Boundary conditions representing inflow and outflow components are implemented using packages in MODFLOW2000. The Recharge Package is used to simulate recharge from precipitation. The Well Package is used to simulate withdrawals from wells, return percolation from irrigation, and effluent from septic systems. The Flow and Head Boundary Package is used to simulate flows to the aquifer from tributary basins and from all lakes except Lake Pend Oreille and Coeur d'Alene Lake. The River Package is used to simulate the Little Spokane River, Lake Pend Oreille, and Coeur d'Alene Lake. The Streamflow-Routing Package is used to simulate the interaction between the Spokane River and the aquifer. The General-Head Boundary Package is used to simulate groundwater outflow from the lower unit at the west end of the Little Spokane River Arm. The spatial distribution of aquifer properties such as hydraulic conductivity and specific yield are represented by dividing the aquifer into zones. Within each zone, the aquifer property is assumed to be uniform.

The parameter estimation program PEST is used to calibrate the SVRP aquifer model. PEST implements a nonlinear least-squares regression method to estimate model parameters by minimizing the sum of squared weighted residuals. Calibration data include 1,573 measurements of water levels and 313 measurements of streamflow gains and losses along segments of the Spokane and Little Spokane Rivers. Weights for the measurements initially are determined from errors associated with the measurements and subsequently adjusted to balance the influence of water-level measurements and flow measurements on the regression.
A total of 38 model parameters are estimated during calibration. These parameters include 22 values of horizontal hydraulic conductivity, 3 values of specific yield, 10 values of vertical hydraulic conductivity of riverbed sediments of the Spokane River, and 3 values of hydraulic conductances for riverbed sediments in the Little Spokane River and for lakebed sediments in Lake Pend Oreille and Coeur d'Alene Lake. An additional four model parameters are not estimated by calibration because the calibration data are insensitive to these parameters. Instead, the parameters are assigned reasonable values.

Model calibration gives the following results. In the central part of the aquifer in Rathdrum Prairie and in Spokane Valley, estimated horizontal hydraulic conductivity $\left(K_{h}\right)$ values range from about 6,200 to 22,000 feet per day. In Hillyard Trough, the Little Spokane River Arm, and Western Arm, estimated $K_{h}$ values range from about 2,000 to 3,000 feet per day. In the Coeur d'Alene area, the estimated $K_{h}$ value is 1,290 feet per day. For side valleys and regions of shallow bedrock along the margins of the aquifer, the estimated $K_{h}$ values range from 4 to 137 feet per day. Estimated specific yield values range from 0.10 to 0.21 . For the Spokane River bed sediments, estimated values of vertical hydraulic conductivity range from 0.01 to 10 feet per day.

In general, the simulated water levels and flows (streamflow gains and losses) are in good agreement with the measured water levels and flows throughout most of the aquifer. The greatest discrepancies between measured and simulated quantities occur in the two wells (wells 99 and 115) completed in the lower unit. These discrepancies indicate that the lower unit might not be represented accurately by the model. For southern Rathdrum Prairie (including the Coeur d'Alene area), simulated water-level fluctuations during 2004 05 do not agree with the observed measured fluctuation. This discrepancy indicates that the temporal distribution of recharge to southern Rathdrum Prairie might not be represented accurately in the model for 2004-05.

The calibrated model gives a 10-year average flow of 67 cubic feet per second $\left(\mathrm{ft}^{3} / \mathrm{s}\right)$ from Lake Pend Oreille to the aquifer, $138 \mathrm{ft}^{3} / \mathrm{s}$ from Coeur d'Alene Lake to the aquifer, and $27 \mathrm{ft}^{3} / \mathrm{s}$ from the lower unit to Long Lake. To examine the assumptions in the SVRP aquifer model, five alternative models are analyzed. In each alternative model, one aspect of the calibrated model is modified and the alternative model is recalibrated. Results of these alternative model analyses show that changes in certain model parameter values can result in changes to certain simulated flow components even though the overall fit of the alternative model to the measured quantities is nearly as good as the calibrated model. This suggests some degree of nonuniqueness in the ground-water flow simulated by the calibrated model. 
The SVRP model presented in this report is calibrated using significantly more data than are used in previous models. The relatively good fit between simulated and measured quantities indicates that the overall simulated ground-water flow is a reasonable representation of ground-water flow in the SVRP aquifer. Nonetheless, the model has limitations. In particular, there is insufficient hydrologic information to determine ground-water inflow from Spirit and Hoodoo Valleys to the SVRP aquifer. In Hillyard Trough and the Little Spokane River Arm, ground-water flow in the lower unit is not well understood, and simulated water levels do not fit measured water levels as well as in other parts of the aquifer. There also is significant uncertainty in the simulated seepages from Lake Pend Oreille and Coeur d'Alene Lake. Further investigations in these parts of the SVRP aquifer could provide valuable knowledge that can be used to improve the model in the future.

\section{Acknowledgments}

The authors thank the following individuals who provided data that were essential for development of the ground-water flow model in this report. Molly Maupin of the USGS collected pumping records from water purveyors for 1990 through 2005. Jon Hortness of the USGS provided estimates of inflows to the SVRP aquifer from tributary basins and adjacent uplands. Reanette Boese of the Spokane County Utilities provided Spokane River stage measurements for 1999-2000. Richard Martindale of the Idaho Panhandle Health District provided information on sewer districts and septic systems in Idaho. Lloyd Brewer of the City of Spokane provided water-use data for Spokane. The staff of the Post Falls, Idaho, and Spokane, Washington, USGS field offices provided support for field data collection. Reviews by Guy Gregory and John Covert of the Washington State Department of Ecology, Joel Massmann of Keta Waters, John Lindgren of the Idaho Department of Water Resources, Gary Stevens of the Idaho Department of Environmental Quality, Lloyd Brewer of the City of Spokane, and Devin Galloway and Richard Yager of the USGS are gratefully acknowledged.

\section{References Cited}

Allen, R.G., and Brockway, C.E., 1983, Estimating consumptive irrigation requirements for crops in Idaho: Moscow, Idaho Water and Energy Resources Research Institute, University of Idaho, 183 p., accessed March 30, 2007, at http://www.idwr.idaho.gov/hydrologic/info/pubs/ misc/Est_Consumptive_Use_08-1983.pdf.
Allen, R.G., Pereira, L.S., Raes, D., and Smith, M., 1998, Crop evapotranspiration: Guidelines for computing crop water requirements: Rome, United Nations Food and Agriculture Organization, FAO Irrigation and Drainage Paper 56, 300 p., accessed March 30, 2007, at http://www. fao.org/docrep/X0490E/X0490E00.htm.

Anderson, K.E., 1951, Geology and ground-water resources of the Rathdrum Prairie project and contiguous area, Idaho-Washington: U.S. Bureau of Reclamation, Kalispell Planning Office, 39 p., 3 pls.

Annear, R.L., Berger, C.J., Wells, S.A., and Cole, T.M., 2001, Upper Spokane River model: boundary conditions and model setup, 1991 and 2000: Technical Report EWR-04-01, Department of Civil Engineering, Portland State University, Portland, Oregon, and U.S. Army Corps of Engineers Waterways Experiment Station, Vicksburg, Mississippi, 307 p.

Bartolino, J.R., 2007, Assessment of areal recharge to the Spokane Valley-Rathdrum Prairie aquifer, Spokane County, Washington, and Bonner and Kootenai Counties, Idaho: U.S. Geological Survey Scientific Investigations Report 2007-5038, 38 p., accessed April 12, 2007 at http://pubs. water.usgs.gov/sir20075038

Bolke, E.L., and Vaccaro, J.J., 1981, Digital-model simulation of the hydrologic flow system, with emphasis on ground water, in the Spokane Valley, Washington and Idaho: U.S. Geological Survey Open-File Report 80-1300, 43 p.

Buchanan, J.P., 2000, Unified groundwater flow model of the Rathdrum Prairie-Spokane Valley aquifer system: Prepared for Water Quality Management Program, Spokane County Public Works and Idaho Division of Environmental Quality: Cheney, Eastern Washington University, 23 p.

Caldwell, R.R., and Bowers, C.L., 2003, Surface-water/ ground-water interaction of the Spokane River and the Spokane Valley/Rathdrum Prairie aquifer, Idaho and Washington: U.S. Geological Survey Water-Resources Investigations Report 03-4239, 60 p., accessed March 30, 2007, at http://id.water.usgs.gov/PDF/wri034239/index. html.

Campbell, A.M., 2005, Ground-water levels in the Spokane Valley-Rathdrum Prairie aquifer, Spokane County, Washington, and Bonner and Kootenai Counties, Idaho, September 2004: U.S. Geological Survey Scientific Investigations Map 2905, 1 sheet, accessed March 30, 2007, at http://pubs.usgs.gov/sim/2005/2905/index.html.

CH2M Hill, 1998, City of Spokane wellhead protection program phase I-Technical assessment report: $\mathrm{CH} 2 \mathrm{M}$ Hill report for the City of Spokane Wellhead Protection Program, 2 vols., variously paged, 12 appendixes. 
CH2M Hill, 2000, Spokane aquifer joint board wellhead protection program, management plan and report appendix: CH2M Hill report for the Spokane Aquifer Joint Board, 3 vols., variously paged, 24 appendixes.

Doherty, John, 2004, PEST model-independent parameter estimation user manual, 5th Edition: Watermark Numerical Computing, variously paged, accessed March 30, 2007, at http://www.sspa.com/pest/pestsoft.html.

Dukes, M.D., Cardenas-Lailhacar, Bernardo, and Miller, G.L., 2005, Residential irrigation based on soil moisture, Resource: Engineering \& Technology for a Sustainable World, v. 12, no. 5, p. 4-6.

Federal Register, 1978, v. 43, no. 28, p. 5556 (February 9, 1978).

Golder Associates, Inc., 2003, Little Spokane (WRIA 55) and Middle Spokane (WRIA 57) watershed planning phase II-Level 1 assessment, data compilation and analysis: Seattle, Golder Associates, Inc., prepared under grant no. 9800300 from the Washington Department of Ecology, variously paginated.

Golder Associates, Inc., 2004, Final report to the Little and Middle Spokane watershed WRIA 55 and 57 planning unit, level 2 technical assessment-Watershed simulation model: Seattle, Golder Associates, Inc., prepared under grant no. 9800300 from the Washington Department of Ecology, February 14, 2004, 51 p., 4 appendixes.

Gregory, J.G., and Covert, J.J., 2005, Spokane River temperature profile, Barker Road to Plantes Ferry Park, September, 2005: Washington State Department of Ecology Publication No. 06-11-005, 15 p., accessed March 30, 2007, at http://www.ecy.wa.gov/biblio/0611005.html.

Gruenenfelder, C.R., 1997, Evidence of a deep confined aquifer system in the Hillyard Trough and Little Spokane River Valley of north Spokane [abs.], in Inland Northwest Water Resources Conference, Program and Abstracts: Inland Northwest Water Resources Conference, Spokane, Washington, April 28 and 29, 1997, 1 p.

Harbaugh, A.W., Banta, E.R., Hill, M.C., and McDonald, M.G., 2000, MODFLOW-2000, the U.S. Geological Survey modular ground-water model-User guide to modularization concepts and the ground-water flow process: U.S. Geological Survey Open-File Report 00-92, 121 p., accessed April 7, 2007, at http://water.usgs.gov/nrp/ gwsoftware/modflow2000/ofr00-92.pdf.
Hill, M.C., 1998, Methods and guidelines for effective model calibration: U.S. Geological Survey WaterResources Investigations Report 98-4005, 90 p., accessed April 7, 2007, at http://water.usgs.gov/nrp/gwsoftware/ modflow2000/WRIR98-4005.pdf.

Hortness, J.E., and Berenbrock, Charles, 2001, Estimating monthly and annual streamflow statistics at ungaged sites in Idaho: U.S. Geological Survey Water-Resources Investigations Report 01-4093, 36 p., accessed March 30, 2007, at http://id.water.usgs.gov/PDF/wri014093/index. $\underline{\mathrm{html}}$.

Kahle, S.C., and Bartolino, J.R., 2007, Hydrogeologic framework and ground-water budget of the Spokane ValleyRathdrum Prairie aquifer, Spokane County, Washington, and Bonner and Kootenai Counties, Idaho: U.S. Geological Survey Scientific Investigations Report 2007-5041, 48 p., 2 pls., accessed May 6, 2007 at http://pubs.water.usgs. gov/sir20075041.

Kahle, S.C., Caldwell, R.R., and Bartolino, J.R., 2005, Compilation of geologic, hydrologic, and ground-water flow modeling information for the Spokane Valley-Rathdrum Prairie aquifer, Spokane County, Washington, and Bonner and Kootenai Counties, Idaho: U.S. Geological Survey Scientific Investigations Report 2005-5227, 64 p., accessed March 30, 2007, at http://pubs.usgs.gov/sir/2005/5227/ index.html.

Landau Associates, Inc., and others, 1991, Colbert landfill remedial design/remedial action, Spokane County, Washington, Volume I of III-Final phase I engineering report: Landau Associates, Inc., [under contract to] Spokane County, Wash., 1 v.

Leake, S.A., and Lilly, M.R., 1997, Documentation of a computer program (FHB1) for assignment of transient specified-flow and specified-head boundaries in applications of the Modular Finite-Difference Ground-Water Flow Model (MODFLOW): U.S. Geological Survey Open-File Report 97-571, 56 p., accessed April 7, 2007, at http:// water.usgs.gov/software/code/ground water/modflow/doc/ ofr97571.pdf.

MacInnis, J.D., Lackaff, B.B., Buchanan, J.P., Boese, R.M., McHugh, J., Harvey, G., Higdem, R., and Stevens, G., 2004, The Spokane Valley-Rathdrum Prairie aquifer atlas 2004 update: Spokane, Spokane Aquifer Joint Board, 26 p.

Murray, Lindy, 2007, Evaluation of boundary conditions and ground-water/surface-water flux at lakes bordering the Spokane Valley-Rathdrum Prairie aquifer, Washington and Idaho: Idaho Falls, University of Idaho, M.S. thesis. 
National Agricultural Statistics Service, 2003, 2004, 2005, Idaho agricultural statistics: Boise, Idaho, USDA National Agricultural Statistics Service Idaho Field Office.

Newcomb, R.C., and others, 1953, Seismic cross sections across the Spokane River Valley and the Hillyard Trough, Idaho and Washington: U.S. Geological Survey Open-File Report 53-199, 16 p., 18 pls.; accessed March 30, 2007, at http://pubs.er.usgs.gov/usgspubs/ofr/ofr53199.

Oad, Ramchand, Lusk, Kevin, and Podmore, Terry, 1997, Consumptive use and return flows on urban lawn water use: Journal of Irrigation and Drainage Engineering, v. 123, issue 1, p. 62-69.

Parliman, D.J., Seitz, H.R., and Jones, M.L., 1980, Groundwater quality in north Idaho: U.S. Geological Survey Open-File Report 80-596, 34 p., accessed April 7, 2007, at http://pubs.er.usgs.gov/usgspubs/ofr/ofr80596.

Pluhowski, E.J., and Thomas, C.A., 1968, A water-balance equation for the Rathdrum Prairie ground-water reservoir, near Spokane, Washington: U.S. Geological Survey Professional Paper 600-D, p. D75-D78, accessed April 7, 2007, at http://pubs.er.usgs.gov/usgspubs/pp/pp600D.

Prudic, D.E., Konikow, L.F., and Banta, E.R., 2004, A new Streamflow-Routing (SFR1) Package to simulate streamaquifer interaction with MODFLOW-2000: U.S. Geological Survey Open-File Report 2004-1042, 95 p., accessed April 7, 2007, at http://pubs.usgs.gov/of/2004/1042/.
Ries, K.G., Steeves, P.A., Coles, J.D., Rea, A.H., and Stewart, D.W., 2004, StreamStats: A U.S. Geological Survey web application for stream information: U.S. Geological Survey Fact Sheet FS-2004-3115, 4 p., accessed March 30, 2007, at http://md.water.usgs.gov/publications/fs-2004-3115/index. $\underline{h t m l}$.

Sagstad, S.R., 1977, Hydrogeologic analysis of the southern Rathdrum Prairie area, Idaho: Moscow, University of Idaho, M.S. thesis, $96 \mathrm{p}$.

Sauer, V.B., and Meyer, R.W., 1992, Determination of error in individual discharge measurements: U.S. Geological Survey, Open-File Report 92-144, 21 p., accessed April 7, 2007, at http://pubs.er.usgs.gov/usgspubs/ofr/ofr92144.

Seitz, H.R., and Jones, M.L., 1981, Flow characteristics and water-quality conditions in the Spokane River, Coeur d'Alene Lake to Post Falls Dam, northern Idaho: U.S. Geological Survey Open-File Report 82-102, 56 p., accessed April 7, 2007, at http://pubs.er.usgs.gov/usgspubs/ ofr/ofr82102.

Walker, E.H., 1964, Ground water in the Sand Point region, Bonner County, Idaho: U.S. Geological Survey WaterSupply Paper 1779-I, 29 p., accessed April 7, 2007, at http://pubs.er.usgs.gov/usgspubs/wsp/wsp1779I. 
This page left intentionally blank 
Manuscript approved for publication, April 9, 2007

Prepared by the USGS Publishing Network,

Bill Gibbs

David Jones

Cathy Martin

Linda Rogers

Bobbie Jo Richey

For more information concerning the research in this report, contact the Washington Water Science Center Director,

U.S. Geological Survey, 934 Broadway - Suite 300

Tacoma, Washington 98402

http://wa.water.usgs.gov 


\section{营}

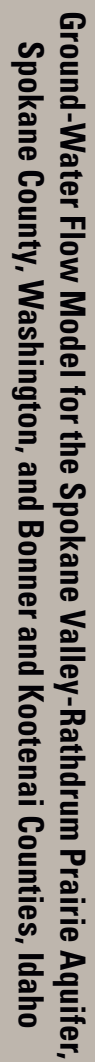

